12-13 черВня 2021, КиїВ ВСЕУКРАЇНСЬКА КОНФЕРЕНЦІЯ 3 МІЖНАРОДНОЮ УЧАСТЮ

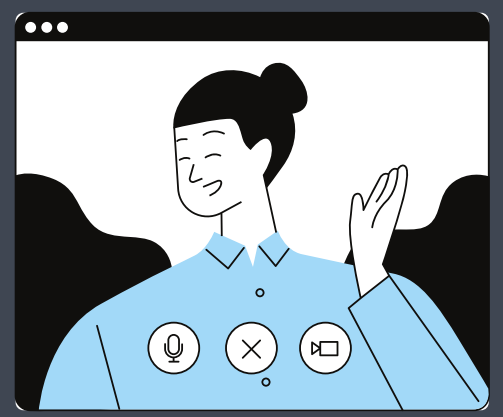

ПСИХОАНАЛІЗ

I BIPTУA^ЬHE:

emuka, мemancuxo^огія

i kлінічнuŭ gocBig

позакабінетної

npakmuku

\title{
МАТЕРІАЛИ КОНФЕРЕНЦІї
}


ГС “Національна психологічна асоціація" України Дивізіон “Психоаналітична психологія і психотерапія" Інститут підготовки кадрів Державної служби зайнятості України Кафедра психології

Криворізький державний педагогічний університет Кафедра практичної психології

Національний медичний університет імені О. Богомольця Кафедра загальної і медичної психології Інститут професійної супервізії Центр практичної психології і психоаналізу “Mental wellness"

\section{ПСИХОАНАЛІЗ І ВІРТУАЛЬНЕ:} етика, метапсихологія і клінічний досвід позакабінетної практики МАТЕРІАЛИ КОНФЕРЕНЦІї

12-13 червня 2021 року, Київ, Україна

Київ • Кривий Ріг

Видавець Роман Козлов

2021 


\section{Рецензенти:}

ПРІБ ГЛІБ АНАТОЛІЙОВИЧ, доктор медичних наук, професор, лікар-психіатр, завідувач кафедри психології Інституту підготовки кадрів Державної служби зайнятості України

МІРОШНИК ЗОЯ МИХАЙЛІВНА, доктор психологічних наук, професор, завідувачка кафедри практичної психології Криворізького державного педагогічного університету, член Дивізіону “Психоаналітична психологія і психотерапія” Національної психологічної асоціації України

МАТЯШ МИХАЙЛО МИКОЛАЙОВИЧ, доктор медичнИХ наук, професор, завідувач кафедри загальної і медичної психології Національного медичного університету імені О. Богомольця

П86 позакабінетної практики :

Матеріали II Всеукраїнської науково-практичної конференції з міжнародною участю, 12-13 червня 2021 року, Київ [Електронне видання].

Київ ; Кривий Ріг : Вид. Р. А. Козлов, 2021. - 240 с. URL: https://5395f838-6b23-4e5e-8873-844b6c1b9700.filesusr.com/ugd/

9da78f_e99e6911f4ca4449acd48cbd76b7810a.pdf

ISBN 978-617-7643-96-7

У збірнику матеріалів подано доповіді та нотатки обговорень у великих групах, що були представлені на II Всеукраїнській науковопрактичній конференції з міжнародною участю "Психоаналіз і Віртуальне: етика, метапсихологія і клінічний досвід позакабінетної практики”, що пройшла 12-13 червня 2021 року в Києві та в додатку Zoom. Ключові спікери конференції були представниками різних психоаналітичних шкіл і осередків, теоретичних поглядів і країн: України, Італії, ПАР, Німеччини, Білорусі. Матеріали, подані у збірнику, стосуються метапсихології психічних явищ у віртуальному вимірі, етики психоаналітичної роботи онлайн, аналізу клінічної практики та прикладних застосувань психоаналізу в полі Віртуального.

Удк 159.964 


\section{MICT}

Вступне слово

Більше не чума? Доля психоаналізу на континенті

Віртуального

7

Мар'яна Великодна

Метапсихологія психоаналізу онлайн

Психоаналіз та психотерапія: між реальним та віртуальним справжнім інструментом $\epsilon$ слово.................................. 16 Едісон Паломіно

Психоаналіз онлайн: будка суфлера чи друга сцена?

Еліна Євланова

Третій (не) зайвий. Монітор у психоаналітичному процесі

Наталія Наливайко

Ave corpus solidum: присутствие и уклончивость тела

в психоанализе Ж. Лакана

Елена Башмакова

\section{Етика психоаналітичної роботи онлайн}

Етичні виклики психоаналітичної роботи онлайн у безпрецедентні часи та поза ними 71 Яел Кейдіш

Новая этика. Любовь, секс и отношения в четвертом измерении 89

Галина Савченко 
Психоанализ очно и онлайн: этика, дискурс, кадр .............. 103 Олег Христенко

Оценка этичности психоаналитической практики онлайн разными профессиональными сообществами

Оксана Аршевская-Герен

Клінічний досвід позакабінетної психоаналітичної практики

Новые реалии. Как быть?

марианна Козлова

Подрамник и полотно психоаналитической работы онлайн..... 145 Валерий Дорожкин

Особенности динамики присутствия и отсутствия при психоаналитической работе онлайн 150 Ольга Павловская

Нарциссическая уязвимость и терапия онлайн 162 Юлия Салий

Аватар на кушетке и сопротивление аналитика

Елена Медведева

Телесное соприсутствие: аспекты работы в реальном и виртуальном пространстве 187 Мария Евграшина

Телефон, скайп и избегание встреч в психоанализе карьерных кризисов. 199 Ярослава Бутенко-Гачковская 
Прикладні застосування психоаналізу в епоху Віртуального

Динаміка психоемоційних станів українців під час пандемії COVID-19: можливості та обмеження онлайн досліджень....... 211 Маріанна Ткалич

Феномен розвитку впевненості у собі в онлайн середовищі .... 216 Ельвіра Македонська

Психосоматичний симптом у призмі групового аналізу..........226 Ірина Франкова

Нотатки конференції

Рефлексії учасників конференції “Психоаналіз і Віртуальне” ... 236 Мар'яна Великодна, Оксана Аршевська-Гєрен 
ВСТУПНЕ СЛОВО 
УДК 159.964

DOI

\section{Мар'яна Великодна}

Психоаналітик ЄКПП, клінічний психолог, кандидат психологічних наук, доцент кафедри практичної психології

Криворізький державний педагогічний університет

Модератор Дивізіону “Психоаналітична психологія і психотерапія”

Національної психологічної асоціації України

https://orcid.org/0000-0001-6269-793X

\section{БІЛЬШЕ НЕ ЧУМА? ДОЛЯ ПСИХОАНАЛІЗУ НА КОНТИНЕНТІ ВІРТУАЛЬНОГО}

У 1903 році на одній з перших виставок автомобілів марки Mercedes у Берліні імператор Німеччини Вільгельм II коментує розробнику: «Так, Ваша машина чудова! Але вона, втім, не така й проста. В будь-якому разі я більше вірю в коней». Більш прямий скептичний коментар у 1898 році на виставці автомобілів промовляє і тогочасний президент Французької республіки Фелікс Фор, називаючи побачене «потворними візками, які жахливо пахнуть». Втім, автомобілі, як ми можемо засвідчити, в подальшому стали більш пріоритетним засобом пересування, ніж коні та візки.

Описані події відбуваються, як ви могли помітити, практично в той же час, як Зигмунд Фройд видає своє «Тлумачення сновидінь» (1900 року). Нагадаю, що книга тоді вийшла тиражем у 600 екземплярів та неквапно розпродавалася цілих 8 років. А сам психоаналіз у той час часто зустрічав таку ж скептичну реакцію публіки, що і автомобілі: модна нісенітниця, не більше. Втім, доволі скоро 3. Фройд пише ще 2 важливі фундаментальні роботи - «Психопатологія буденного життя» (1901) та 
«Три нариси з теорії сексуальності» (1905) - і уже в 1909 році, пливучи на пароході Джордж Вашингтон до Америки, він скаже своїм молодим колегам, Карлу Густаву Юнгу та Шандору Ференці, «вони і не уявляють, яку чуму ми їм веземо». I 3. Фройд опиняється правим - психоаналіз стає панівною теорією та клінічною практикою на різних континентах на довгі десятиліття, пізніше зайнявши почесне місце серед плеяди інших психотерапевтичних напрямків.

Революційний підхід, наполягання на правді клінічних відкриттів, спроби описати і переописати, скоригувати свої ж теорії психічних процесів, а також готовність застосовувати психоаналітичний дискурс для опису багатьох інших сфер буття (соціальні процеси, культуральні явища, мистецтво і т.д.) знакові для психоаналізу на його початку. Психоаналіз того часу рішуче вдосконалює і наполегливо поширює свою “чуму”. Припускаю, що саме задля цього поширення багато чого у психоаналітичні теорії для опису психічного життя було запозичене також і з дискурсу технологічного прогресу: поняття психічного anapamy, механізмів захисту - класичний приклад.

Втім, ми знаємо також і подібні періоди опору, які на певний час ставали на заваді новим відкриттям у самому психоаналізі. Наприклад, відома доповідь Сабіни Шпільрейн (1912) про деструкцію як причину становлення спершу була розгромлена 3. Фройдом, оскільки йшла в розріз із описаним ним принципом задоволення. Однак уже через 8 років він і сам визнає існування чогось по той бік принципу задоволення (1920) завдяки своїй клінічній практиці та визнає наявність смертєпотягу. По суті ми бачимо, що 3. Фройду був потрібен час на опрацювання того, що спершу було представлене йому надто рано. Сюди ж можна віднести початкову неготовність адаптувати психоаналітичну техніку до не-невротичних пацієнтів, особливо психотиків, що було пізніше блискуче втілене практиками наступних поколінь. 
Цікаво, що такі ж реакції - відторгнення і рішучого «ні», а потім із часом поступового прийняття і віднайдення сильних сторін - описують у своїх роботах деякі психоаналітики щодо свого ставлення до онлайн консультацій (Kudiyarova, 2018; Eiguer, 2018). За останнє десятиліття більшає коротких клінічних і фундаментальних робіт (Lemma, Caparrotta, 2013; Russell, 2018; Scharff, et al., 2018), що присвячені психоаналітичній практиці у віддаленому форматі. Вони фокусуються на різних iї аспектах:

- що означає поява засобу зв'язку та його проявів на сесіях для позасвідомого суб'єкта (так, I. Dettbarn (2018) міркує про Skyре як про жахаюче, тобто Фройдове “uncanny”, і порівнює з караючим суперего; E. Malater (2020) рефлексує щодо значення кнопки “leave meeting” у Zoom, яку натискає аналізант в кінці сесії; M. Gerald (2011) вказує на подвійну картинку, в якій кожен суб'єкт сесії бачить не лише співрозмовника, але і себе самого; D. Neumann (2018) говорить про вплив інтернетзасобу зв'язку на хід асоціацій та перенесення/контрперенесення);

- як саме брак невербальної інформації (коли неможливо спостерігати ціле тіло аналізанта і відповідати йому всім тілом) впливає на комунікацію в аналітичному діалозі (Bayles, 2012; Merchant, 2016; Brahnam, 2017; Neumann, 2018; Elise, 2020; Wolson, 2021), включаючи можливість діагностики (Biliavska, 2021);

- як залучення інтернет-гаджету впливає на аналітичну увагу і техніку (R. Fishkin та співавтори (2011) піднімають питання про перехід від “вільно плаваючої уваги” до “уваги у вільному плаванні”, яка перескокує на всі іконки і нові повідомлення, які спливають на екрані в аналітика, що відволікає від слухання; у секційному звіті G. Bodner (2017) розширено ідею G. Russel, що віддалений аналіз має справу зі “станами розуму”, ніж зі “станами буття”; C. Juhos, J. Mészáros (2019) 
відзначають вплив віддаленого формату на сетинг роботи; D. Lichtenstein (2021) описує зміну ваги зору та слуху в аналітичній роботі);

- який засіб віддаленого зв'язку може бути пріоритетним (скажімо, D. Miermont-Schilton пропонує Skyре для психотерапії, але телефонний дзвінок для психоаналізу; тоді як Ј. Churcher доводить ненадійність безпеки Skype);

- чим викликаний особистий та інституційний опір проводити психоаналіз віддалено (Caparrotta, 2013; Scharff, 2013) та які це має наслідки на становлення психоаналізу (Aryan, Carlino, 2018);

- як налагодити етичність (Schön, Kadish, Green, Hanson, Kuhn, 2018; Wallwork, 2018) та законність такої практики (наприклад, у США аналітик зобов'язаний мати ліцензію на практику як у власному штаті, так і в штаті, в якому знаходиться аналізант, див. Scharff, 2018).

У 2020 та 2021 році можна спостерігати бум робіт з теми позакабінетної практики психоаналізу у зв'язку з дотриманням карантинних заборон через пандемію COVID-19. У випадку, якщо це перший досвід онлайн-сесій психоаналітиків, клініцисти фактично описують наслідки накладання цього подвійного досвіду: 1) загальнолюдської кризи через коронавірус та 2) переходу у віддалений формат роботи, що, як на мене, суттєво відрізняє фокус цих спостережень (Kegerreis, 2020; MiermontSchilton, Richard, 2020; Rizq, 2020; Pozzi Monzo, Micotti, 2020; Castrillón, Marchevsky, 2021; Hart, 2021; Lichtenstein, 2021). Втім, більшість авторів відзначила цінність дистанційних сесій для підтримки аналітичних стосунків (напр. Rossi, Ferro, 2020; Lichtenstein, 2021).

Кілька власних клінічних спостережень та досліджень віддаленої психоаналітичної практики опублікувала у зазначений період і авторка цих строк (Velykodna, Tsyhanenko, 2020; Velykodna, Tsyhanenko, 2021; Velykodna, 2021). В цілому, гадаю, 
нам ще належить доповнити і систематизувати свої спостереження і рефлексії стосовно онлайн-роботи, аби бути готовими до фундаментального вивчення ії особливої феноменології.

Проте, гадаю, що поле психоаналітичних питань щодо Віртуального на сьогодні значно ширше за суто етичні та організаційні:

1. Якщо припустити, що Віртуальне - стало новим континентом, мегаполісом нашого співмешкання, керованого алгоритмами інтернет-мереж, то які нові явища психології мас ми можемо тут спостерігати?

2. Якщо суб'єкт і суб'єкт аналізу віртуалізується - то яким $\epsilon$ метапсихологія його існування у цьому новому просторі?

3. Які сліди і наслідки може мати зв'язок між двома у віртуальному полі? Зв'язок, такий подібний до сновидіння: де тіло знаходиться нерухомим в одній кімнаті, однак бачить, чує, уявляє і навіть змінюється від віртуального впливу на нього?

4. І якщо ми вирішимо, що коні вічні, тобто що Віртуальність - це щось шкідливе, чому важливо протистояти - то чи не вартий цей континент того, щоби ми активно поширили там свою чуму - запросивши до земного і втіленого у наших психоаналітичних кабінетах?

\section{Література:}

1. Aryan, A., \& Carlino, R. (2018). The power of the establishment in the face of change: psychoanalysis by telephone. In Psychoanalysis Online (pp. 161170). Routledge.

2. Bayles, M. C.S.W. (2012). Is Physical Proximity Essential to the Psychoanalytic Process? An Exploration Through the Lens of Skype, Psychoanalytic Dialogues, 22:5, 569-585, DOI: 10.1080/10481885.2012.717043

3. Biliavska, O. (2021). Operationalized psychodynamic diagnostics (OPD2) as a step to the controlled practice [In Ukrainian] In Life and death of psychoanalytic societies: lessons from history and new prospects for unions : Conference proceedings. The I-st All-Ukrainianonline conference with international participation, January, 23-24, 2021, Kyiv[electronic book]. pp. 138-140. 
4. Bodner, G. (2017). Panel report, IPA Congress Buenos Aires 2017: Intimacy and technology: Developing a psychoanalytic dialogue. The International Journal of Psychoanalysis, 98(6), 1800-1802.

5. Brahnam, S. (2017). Comparison of in-person and screen-based analysis using communication models: A first step toward the psychoanalysis of telecommunications and its noise. Psychoanalytic Perspectives, 14(2), 138-158.

6. Caparrotta, L. (2013). Digital technology is here to stay and the psychoanalytic community should grapple with it. Psychoanalytic Psychotherapy, 27(4), 296-305.

7. Castrillón, F., \& Marchevsky, T. (Eds.). (2021). Coronavirus, Psychoanalysis, and Philosophy: Conversations on Pandemics, Politics and Society. Routledge.

8. Churcher, J. (2012). On: Skype and privacy. The International Journal of Psychoanalysis, 93(4), 1035-1037. https://doi.org/10.1111/j.17458315.2012.00610.x

9. Dettbarn, I. (2018). Skype as the uncanny third. In Psychoanalysis Online (pp. 15-25). Routledge.

10. Eiguer, A. (2018). Psychoanalysis via Skype: A contemporary challenge. Vertex (Buenos Aires, Argentina), 29(137), 34-40.

11. Elise, D. (2020). The Erotic Body. Psychoanalysis.Today, Issue 12: The Body and Psychoanalysis. (electronic journal). Available at https://www.psychoanalysis.today/en-GB/PT-Articles/Elise144989/The-Erotic-Body.aspx?utm_ source=Psychoanalysis.today $+($ English $) \& u t m \_c a m p a i g n=5 b 7875 f 108$ -

EMAIL_CAMPAIGN_2020_12_19_02_23\&utm_medium=email\&utm_term=0_458 bb99253-5b7875f108-135253762 [Google Scholar]

12. Fishkin, R., Fishkin, L., Leli, U., Katz, B., \& Snyder, E. (2011). Psychodynamic treatment, training, and supervision using internet-based technologies. Journal of the American Academy of Psychoanalysis and Dynamic Psychiatry, 39(1), 155-168.

13. Freud, S. (1953). The interpretation of dreams (1900). In The standard edition of the complete psychological works of Sigmund Freud, Vol. 4.

14. Freud, S. (1953). The psychopathology of everyday life (1901). In The standard edition of the complete psychological works of Sigmund Freud, Vol. 6.

15. Freud, S. (1953). Three essays on the theory of sexuality (1905). In The standard edition of the complete psychological works of Sigmund Freud, Vol. 7.

16. Freud, S. (1953). Beyond the pleasure principle (1920). In The standard edition of the complete psychological works of Sigmund Freud, Vol. 18.

17. Gerald, M. (2011). The psychoanalytic office: Past, present, and future. Psychoanalytic Psychology, 28(3), 435. 
18. Hart, A. (2021). De-interpersonalization. Psychoanalytic Psychology, 38(2), 105-106. https://doi.org/10.1037/pap0000344

19. Juhos, C., \& Mészáros, J. (2019). Psychoanalytic psychotherapy and its supervision via videoconference: experience, questions and dilemmas. The American journal of psychoanalysis, 79(4), 555-576.

20. Kegerreis, S. (2020) Some thoughts on working psychoanalytically through the pandemic - The state of the good object, Psychodynamic Practice, 26:4, 364-368, https://doi.org/10.1080/14753634.2020.1830657

21. Kudiyarova, A. (2018). Psychoanalysis using Skype. In Psychoanalysis online. Routledge. 183-193.

22. Lemma, A., \& Caparrotta, L. (Eds.). (2013). Psychoanalysis in the technoculture era. Routledge.

23. Lichtenstein, D. (2021). Are you there? Psychoanalytic Psychology, 38(2), 107-108. https://doi.org/10.1037/pap0000361

24. Malater, E. (2020). The Logical Time of Ending a ZOOM Session as a Metaphor for the Terror of the Current Situation. European Journal of Psychoanalysis. Issue "Psychoanalysts Facing Coronavirus".

25. Merchant, J. (2016). The use of Skype in analysis and training: a research and literature review. Journal of Analytical Psychology, 61(3), 309-328. https://doi.org/10.1111/1468-5922.12224

26. Miermont-Schilton, D., \& Richard, F. (2020). The current sociosanitary coronavirus crisis: remote psychoanalysis by Skype or telephone. The International Journal of Psychoanalysis, 101(3), 572-579. https://doi.org/10.1080/00207578.2020.1773633

27. Neumann, D. A. (2018). The frame for psychoanalysis in cyberspace. In Psychoanalysis Online (pp. 171-181). Routledge.

28. Pozzi Monzo, M., \& Micotti, S. (2020). 'Making the best of a bad job': a literature review on digital psychoanalytic psychotherapy with children, adolescents and families at the time of the Covid-19 pandemic. Journal of Child Psychotherapy, 46(3), 273-280. https://doi.org/10.1080/0075417X.2021.1878549

29. Rizq, R. (2020) What have we lost?, Psychodynamic Practice, 26:4, 336-344, https://doi.org/10.1080/14753634.2020.1845068

30. Russell, G. I. (2018). Screen relations: The limits of computer-mediated psychoanalysis and psychotherapy. Routledge.

31. Rossi, R. S., \& Ferro, M. (2020). Skype as a protected means to live a relationship. In International Forum of Psychoanalysis (Vol. 29, No. 3, pp. 188-191).

32. Scharff, J. S. (2013). Technology-assisted psychoanalysis. Journal of the American Psychoanalytic Association, 61(3), 491-510.

33. Scharff, J. S. (2018). Teleanalysis beyond Skype. In Psychoanalysis Online 3 (pp. 1-19). Routledge. 
34. Scharff, J. S. (Ed.). (2018). Psychoanalysis online: Mental health, teletherapy, and training. Routledge.

35. Schön, J., Kadish, Y., Green, J., Hanson, S., \& Kuhn, J. (2018). Psychotherapy in the age of technology: the ethical challenges of online treatments for South African clinicians. Psycho-analytic Psychotherapy in South Africa, 26(1), 30-53.

36. Spielrein, S. (2018). Destruction as the Cause of Becoming (1912). In The Essential Writings of Sabina Spielrein (pp. 97-134). Routledge.

37. Velykodna, M. (2021). Psychoanalysis during the COVID-19 pandemic: several reflections on countertransference. Psychodynamic practice. Vol.27. Issue 1. p. 10-28. doi: $10.1080 / 14753634.2020 .1863251$

38. Velykodna, M., Tsyhanenko, H. (2021). Psychoanalysis and psychoanalytic psychotherapy in Ukraine during the COVID-19 pandemic unfolding: the results of practitioners' survey. Psychological journal. Volume 7, Issue 1. p. 20-33. https://doi.org/10.31108/1.2021.7.1.2

39. Velykodna, M., \& Tsyhanenko, H. (2020). Which theories and conceptions do psychoanalysts and psychoanalytic psychotherapists consider helpful in their practice during the COVID-19 pandemic unfolding in Ukraine?. Psychological journal, 6(8), 88-100. https://doi.org/10.31108/1.2020.6.8.7

40. Wallwork, E. (2018). Thinking ethically about beginning online work. In Psychoanalysis Online 2 (pp. 83-92). Routledge.

41. Wolson, P. (2021). Some pros and cons of psychoanalytic teletherapy. Psychoanalytic Psychology, 38(2), 109-110.

https://doi.org/10.1037/pap0000348 


\section{МЕТАПСИХОЛОГІЯ ПСИХОАНАЛІЗУ ОНЛАЙН}


Удк 159.964

DOI

\author{
Едісон Паломіно \\ Фахівець з психоаналітичної психотерапії, \\ практик клінічного психоаналізу в Мілані. \\ Член Лаканівської школи психоаналізу Фрейдова поля. \\ Редактор "Lacanpertutti" \\ https://orcid.org/0000-0002-9295-3380
}

\title{
ПСИХОАНАЛІЗ ТА ПСИХОТЕРАПІЯ: МІЖ РЕАЛЬНИМ

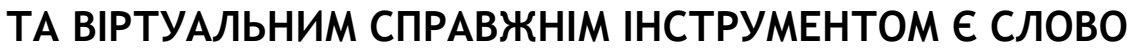

Добрий день. Дякую за люб’язно надану мені можливість узяти участь в конференції, присвяченій психоаналізу. Для мене це честь розділити з Вами цей момент через те, що я назву моїм внеском у неї.

Назва цієї конференції «Психоаналіз та Віртуальне: етика, метапсихологія і клінічний досвід позакабінетної практики» в часи Коронавірусу вводить нас у центр психоаналітичного досвіду, без якого не було б місця для психоаналізу. Принаймні для психоаналізу Фройда, етика якого не Держави, не бюрократії і їі деонтології, а Позасвідоме. І позасвідоме - це той цензурований розділ, який робить кожного з нас маріонеткою мови, частиною якої і $\epsilon$ позасвідоме. Німецький драматург Генріх фон Кляйст, у своїй роботі «Про театр маріонеток» (1), дає можливість доторкнутися до такого виміру позасвідомого як гравітація, яка керує всім рухом.

Закони Держави - це те, що стосується кожного і в $є$ цьому плані $є$ дегуманізуючим. Позасвідоме - навпаки, це те, що відсилає до радикальної особливості кожного з нас, до власної особливої насолоди. Воно $є$ фактором слів і має відношення 
до закону непорозуміння. I тут ми можемо стверджувати з Лаканом, що колективне позасвідоме не існує, «є тільки позасвідоме сингулярне, тому що кожний, в будь-який момент, підкориговує мову, якою говорить» (2). Тому в людському спілкуванні неможливо сказати те, що хочеться; в результаті повідомляється щось інше. I все це відбувається з причини початкового непорозуміння, власне Позасвідомого, яке для Фройда $\epsilon$ нічим іншим як усним знанням і з цієї причини є об'єктом інтерпретації.

Це приводить нас до виміру Іншого, який враховує можливість зберігання законів Держави, щоб утворити простір для сингулярності кожного співрозмовника. Особливо в такі часи, коли $є$ постійне розмноження методів і технік спрямованих на нормалізацію людини спричинивши таким чином анулювання іiі суб'єктності.

Таким чином суб'єкт є під загрозою маленького масштабу. I я говорю маленького масштабу, тому що справжньою небезпекою $є$ загроза великого масштабу, до якої відноситься постійний технологічний прогрес, включаючи такі галузі як Штучний інтелект, нанотехнології, робототехніка, одним із завдань яких $є$ стирання границь між реальністю та фантазією. Іншими словами знищення людської суб'єктності, тобто його сингулярності утвореної з первісного непорозуміння до якого відносяться мимовільні помилки, невдалі дії, забудькуватість та сновидіння.

В результаті, людина без позасвідомого - це марення, 3 яким, якщо збудеться, треба буде мати справу.

Винахідники технологій свято переконані, що технологія йде назустріч людському організму роблячи його менш хитким, тобто більш стійким та довговічнішим у протистоянні із природними незгодами. І мозок такий хиткий, ненадійний та повільний у своїй роботі буде підсилений до свого максимального рівня нанотехнологією, яка також має інше ім'я: невидима 
технологія. Це може статися також з нашим ДНК та з кожною частиною нашого організму.

Ці невидимі охоронці матимуть завдання захищати від зовнішніх патогенів, серед яких і віруси, та знищувати їх, а також відновлювати те, що можливо буде знищеним. Так, людина майбутнього, згідно Рея Курцвейла, буде злиттям генетики, нанотехнології та робототехніки, відома як генерація $\operatorname{GNR}(3)$.

Це все здається фантастикою. Також нею здається ідея краху політичної системи з причини наявного бурхливого технологічного прогресу. Це примусить людство розробити нову форму політики, яка не буде обмеженою нашою планетою, а буде розширеною на Всесвіт, яку Олаф Степлдон називає галактичне Суспільство Світів (4).

Те, про що розповідали нам у своїх фантастичних романах Сиапледон та Айзек Азімов, здається зараз стає реальністю. Достатньо відкрити працю «Майбутнє людства» (5) фізика Мікіо Каку, щоб дізнатись яким уявним диявольством може бути піддане людство в зв'язку з його бажанням заселити Всесвіт. В рамках цієї книги читаємо «Від життя на Марсі до безсмертя». Марс, із приземленням марсоходів Perseverance та китайського Zhurong, $\epsilon$ однозначно реальністю. В той час як безсмертя залишається бажанням сучасної людини.

Це бажання має комічну сторону, як вважає Мішель де Монтейн, згідно якого, якщо б людина була б безсмертною вона оплакувала б все життя неможливість померти (6).

Кожна зміна в світі передбачає заміну, анулювання та передусім зміну парадигми. 3 цієї ж галузі $\epsilon$ криптовалюти Біткоїну, які погрожують започаткувати нову економічну еру. В майбутньому, можливо, з'явиться якийсь уряд, який зробить цей революційний крок.

Як ми не можемо ігнорувати ці аспекти, так ми не можемо ігнорувати ризик природних катастроф як наслідок людського забруднення, яке може спровокувати екологічні катастрофи 
великого масштабу. Лакан казав «там де $\epsilon$ хаотична купа відходів, є людина. [...] ось один із аспектів людської природи, який необхідно визнавати» (7). І тут ми можемо описати лабіринти людської суб'єктності за допомогою латинського прислів'я:

«Heu patior telis vulnera facta metis» - Я страждаю від ран, нанесених моїми власними дротиками.

Справді ми займаємося лікуванням в громадських клініках, приватних та наших власних Студіях. Але також правда, що психоаналітичний досвід не $є$ аутистичним, тому він має брати до уваги соціально-політичні зміни, які мають сильний вплив на сучасну суб'єктність. Психоаналіз буде лише в тому випадку, якщо він буде відповідати суб'єктності епохи, говорив Лакан (8).

Для батька психоаналізу під ліжком аналітика протікає місто зі всіма його трагедіями і драмами. І симптом страждання завжди співвідноситься з бажанням Іншого, і цей Інший може бути також соціальним Іншим.

\section{НАУКА І ПОТЯГ ДО СМЕРТІ}

Психоаналіз з людської істоти витягнув назовні найгірше. Те, що живе в серці іï суб'єктності, тобто потяг до смерті через який підкреслюється схильність людини до самознищення.

І цим відкриттям влітку 1932 року Фройд освітлює відповідь на питання Ейнштейна, що робити, щоб тримати подалі від людей невідворотність війни (9).

Фройд, у своєму листі-відповіді, пише що потяг до смерті «функціонує в кожній живій істоті і що його призначення привезти їі до руйнування, до стану неживої матерії» (10). У своєму творі «Майбутнє однієї ілюзії» він казатиме, що людина - це слабка розумна істота, над якою домінують імпульсні бажання (11). Ця природна людська схильність проявляється у різних формах та відтінках...

Потяг, як постійна сила, націлений на анулювання слова та рамок, які воно вводить для медіації відносин між собі 
подібними. Боротьба, агресивність, насильство, престиж - це деякі з імен потягу до смерті. І для того, щоб впоратися з тілом повним потягів, Фройд ставить в центр людських відносин слово. Яке єдине в стані бути посередником, обмежувати та завадити знищенню іншого.

Для французького письменника Анатоля Франца, якому Ференці присв'ячує розділ «Анатоль Франц, психоаналітик» (12), є два досконалих людських об'єкти: релігія та наука. Про релігію говориться, що вона призначає сакралізацію старих звичок та життя в рабстві. Про науку - що необхідно змусити їі проникнути у небо, щоб привнести трохи свободи (13).

Для Фройда навпаки - релігія це найцінніший піднесений об'єкт, будь-коли створений людиною. «Вона дозволяє людині, в уявний спосіб, ввести символічні рамки», які Фройд називає «скарб уявлень» (14), для того, щоб впоратися з реальністю.

Справжня релігійна людина, згідно Фройду, $\epsilon$ та, яка відмовляється від земного життя заради божественного, не та, хто задовольняється своєю недостатністю, але та, хто старається виправити свою природну слабкість. Також з цієї причини він казатиме, що наука $є$ ілюзією (15).

У такий спосіб він вводить людину науки, яка заповнена бажанням направленим на зцілення людства від своєї безпомічної природи. I з цим бажанням, яке вона до кінця не розуміє, ризикує почати те, що Лакан називає «ненажерливим птахом» дійсності.

Лакан формалізує це визначення в своєму семінарі «Етика психоаналізу», в якому виділяє містичне бажання, яке живе в науці. Власне під кінець свого виступу казатиме:

“Важливо не мати знання чи людина від своєї природи добра або погана, а важливо знати, що станеться поза книжкою, коли вона буде повністю поглинута"(16).

В одному інтерв'ю італійському журналу Панорама, Лакан висвітлює всі проблеми, які несе з собою бажання знань нау- 
ковця, ризики та наслідки, яким він піддається під час своїх пошуків та експериментів в лабораторії.

“Біологами їх називають, (каже Лакан) або фізиками або хіміками. Для мене вони божевільні”. І продовжує “Тільки зараз, коли вони ось-ось зруйнують всесвіт, їм приходить на думку спитати чи може це бути небезпечним? А якщо вибухне все? А якщо бактерії, які вирощені в лабораторії з любов'ю, мутують у смертельних ворогів? А якщо світ буде зметеним ордою тих бактерій, разом з усіма неприємними речами, які його наповнюють, починаючи з науковців лабораторій?”(17).

В цей спосіб Лакан до трьох неможливих позицій Фройда: управляти, виховувати, психоаналізувати, вводить четверту наука. Позиція якої, нестерпне незнання співпадає з твердженням Фройда у своїх останніх рядках про недоліки цивілізації:

“Людство зараз так розширило свою владу над природними силами, що користуючись ними може легко знищити само себе, аж до останньої людини” (18).

Потяг до смерті ми відчуваємо в кожній галузі діяльності, у своїй непомітно тихій формі. Як у тенденції, в поштовху людини до оцифрування Всесвіту. Маючи на увазі Всесвіт, згідно Гете, як організм у постійній трансформації (19).

Наука націлена на добро для людини, але добро, згідно з Лаканом, це форма влади, а влада для Фройда - це одне 3 імен насильства. На кону завжди занадто багато в цій справі, i це забагато це те, що ми знаємо під ім'ям - насолода. Також з цієї причини психоаналітик не робить із себе доброго самаритянина. Ми не робимо ніякої благодійності також тому, що симптом не робить знижок.

Франсуаз Дольто визначила аналітика як хамелеона, якого важко обманути (20).

Нові форми влади введені для боротьби з COVID-19 - того порядку, які у своєму творі “1984”(21) передбачив Орвелл, тобто контроль урядів над масами: все бачиться, все чується. 
Фізична дистанція та нові форми віртуального соціального життя $\epsilon$ проявами цього порядку. Цей тренд до віртуального не $\epsilon$ породженням COVID-19, а $є$ тим, що вже було перед ним i що пандемія формалізувала.

Удари нанесені вірусом змінили уявне колективне та нашу клініку. І остання частина назви конференції «клінічний досвід позакабінетної практики» пов'язана з цією епохальною зміною перед та після пандемії COVID-19.

Теоретичні семінари та контролюючі аналізи, які були введені одразу ж після створення Міжнародного комітету 3 Підготовки у далекому 1925 році, перейшли з живої форми у віртуальну. Достатньо пошукати на Youtube, щоб віднайти нескінченну кількість семінарів та конференцій різних психоаналітичних шкіл, які відбулися у цей перший рік ізоляції. Також у нашій галузі вірус зробив психоаналітичне знання доступним до широких мас.

Віддаленість спричинила до появи цієї форми зустрічі, через екран, з тілом іншого у своїй спектральній формі, незалежно від місця розташування.

Декілька тижнів тому назад Жак Алан Міллер з'явився перший раз у віртуальному полі, представляючи свою нову книжку «Політична полеміка». Під кінець презентації він заявив, що почував себе дуже добре. І справді, через декілька тижнів він мав іншу конференцію для російських колег. Скільки триватиме ця справа, ця перевага віртуального ще треба зрозуміти.

\section{В НАПРЯМКУ СЛОВА}

На фоні усіх цих змін дуже важливо запитати себе про місце, яке займатиме слово, яку форму воно прийняло і як воно працює в часи домінації науки.

Наука, в основному, це комунікаційне поле, а комунікація це щось, що протиставляє себе слову, як стіна. І в цей спосіб наука анулює суб'єктність. 
Фройд у своєму проекті наукової психології підкреслив неможливість звузити людський досвід до комунікації, тобто спілкування статистичного, кількісного та метричного аргументуючи це тим, що досвід не базується на операціях вимірювання (22), а базується на чомусь, що зберігає правду. Правда, яке має відношення до історії персони у своїй останній інтимності - це слово.

Слова для древніх були як магія, заклинання за допомогою яких підтримувались стосунки з божествами. За допомогою слів вибудовуються романи, міфи, робляться війни, завойовуються імперії, досягаються найвіддаленіші зірки Всесвіту, навіть! Казав Густав Флабер, що можна заставити танцювати зірки (23).

I за допомогою слова Ісус, направляючи погляд до неба, ввів у людську уяву існування Отця поза світом.

«Батько, прости їм, бо не відають, що творять» (Luca 23,33-46).

І словами віддається належне любові до батька, матері, а також до жінки. Поети це знають, для них любов і поезія зв'язані постійним романом. Роберт Барнс, один з любимих поетів Фройда, писав:

До того як висохнуть моря, кохана моя.

І скелі розтануть під сонцем!

Любитиму ще тебе, кохана моя,

В той час як тече пісок життя (24).

Ця маленька цитата освітлена потужністю слова «Любов», яким можна навіть розплавити камінь. Тарас Шевченко у своєму «Заповіті», такими словами, віддає належне своїй любій Україні, своєму коханню.

Як умру, то поховайте

Мене на могилі

Серед степу широкого

На Вкраїні милій (25). 
Той самий Лакан у семінарі «Заключний момент»(26) говорить, що аналіз не $\epsilon$ без поезії, тобто такої точки, в якій сформульовані мовлене та висловлене.

I починаючи з цього формулювання ми переносимось в інший вимір слова, яке існує не тільки для комунікації, розповіді або вираження почуттів, як в поезії, в скульптурі, а й для виклику. I через цей новий вимір слова для суб'єкта $\epsilon$ можливість історізувати свою історію: хліб його правди.

Едіп Софокла, наприклад, ніколи не ходив до аналітика, але його правда була відновлена першим психоаналітиком в історії. Він, через цей міф, виділив цю остаточну правду, що становить наше Буття. Це правда, яка відкриває пекельну сторону знання. Едіп, який не читав Фройда, хоче пізнати правду за будь-яку ціну. Начебто правда це щось таке легке та стерпне. I він наполягає і правда говорить: “Я, правда, говорю”. І коли правда говорить - гримить, розриваючи землю. Насправді трагедія Едіпа не у втраті очей, а в зустрічі зі своєю пекельною правдою. Едіп $\epsilon$ ураженим у саму інтимність свого Буття викликом слова, яке заключає в собі правду. I інтимність Буття, в залежності від випадку, показує себе симптомами у неврозах або розладом в психозі.

Лакан у своїй конференції «Функції та поле мови та мовлення» (27), яка відбулася у Римі в 1953 році, відновлює цей фундаментальний пристрій психоаналітичного досвіду - слово. I в той час як мовлення, тонке тіло, $\epsilon$ матрицею, слово $\epsilon$ його окремим об'єктом, в тілі якого знаходяться три регістри людського досвіду: Уявне, Символічне, Реальне.

Тих, хто приходить до нас, ми просимо говорити, але не для того щоб зрозуміти, бо зрозуміти означає оволодіти знанням і в цей спосіб вичерпати його, а для того щоб схопити сузір'я змістів, з яких будується його правда.

Тіло слова - це не тіло організму, вале оно також може отримати уявні травми, які його засмучують. 
Межі, які зустрічає слово, ми знаходимо у девізі Фройда «l слово стає матерією». Цей девіз є прикладом травми, розриву, які терпить тіло слова, і наслідки яких ми можемо побачити у нашому клінічному досвіді з психотичними суб'єктами, а також в літературі, і понад усе - у повсякденному житті.

В газетах можна прочитати новини про знущання над жінками або їх убивства, статті про чоловічу ненависть, яка прикриває феміцид. Всі ці випадки є прикладом розірваного тіла слова, уявні наслідки від якого приймають диявольську форму.

У Джеймса Джойса ми знаходимо інший приклад травматичних наслідків, які продукує розірване тіло слова.

У творі “портрет артиста в Молодості” (28) ми є свідками накладання слів голосів батьків, викладачів, шумів товаришів, які їдять у їдальні, та слів з релігійної тематики, які відсилають нас до очищення тіла та душі:

«Було б краще ніколи не грішити, залишаючись назавжди дитиною»(29).

Існують також слова, які випливають на поверхню, як наприклад «Foetus», відокремлена частина, слід того, що Стів називає індивідуальною тваринною хворобою його розуму. В одному листі від 29 серпня 1904 року Джойс пише Норі:

“Кожне слово приводить моє серце у збуджений стан, як птах під в непогоду"(30).

Слово вводиться в організм через його дірки перевертаючи його сутність, роблячи його чутливим, еротичним, озвучуючи та рухаючи ним наче іграшкою. В наслідок травм, які отримує слово, воно стає уявним об'єктом або навіть реальним в суб'єкті. У своєму семінарі про “Симптом” Лакан визначає слово як паразит, як форму раку, яка уражає людство(31).

У своїх дослідженнях про Істерію, Фройд ставить нас перед владою слова, яку визначає як основний інструмент психічного лікування (32). І психічне, як мапа слова, є суб'єктом законів означального ланцюга. Так слово робить вузол значення (33). 
Істерія $є$ найкращим прикладом укусу слова організму, на тілі. Цей укус, каже Фройд, затіняє правду, яка складає серце симптому. Анна О., пані Елізабет Р. і той самий випадок чоловічої істерії $є$ тільки деякими свідченнями слова, яке вписується на тілі. Те, що ми знаємо під словом психосоматика, $\epsilon$ свідченням влади слова: плачі, усмішки та інша форма вираження $\epsilon$ нічим іншим як записом слова на тілі (34). Деякі учні Фройда навіть визнавали слово як першопричину виникнення деяких ракових захворювань.

У своєму основному “Інтерпретація снів” (35), Фройд представляє нам анатомію сну, зробленого із семантичних конденсацій і переміщень: метонімія та метафора. Сон має структуру фрази, напису. I тому сни відіграють таку важливу, якщо не головну, роль у житті людини. Для Самі Алі сни це мости до походження (36).

Згідно з Фройдом, сни як абсурдна семантична конденсація, мають форму психозу. Тому до переміщення та конденсації Фройд додає драматизм.

$€$ інший текст Фройда під назвою «Über den Gegensinn der Urworte», (Антитетичне значення примітивних слів), опублікований перший раз у 1910 році, в якому він продовжує роботу філолога Карла Абеля для підкреслення влади мовлення і своїх елементів: означальне і значення. Можливо тому Лакан вважає Фройда попередником Фердінанда де Сосюра, батька сучасної лінгвістики. Фройд завершує свій маленький допис в такий спосіб:

“І ми, психіатри, не можемо уникнути підозри, що ми розумітимемо та інтерпретуватимемо краще мову снів, якщо б ми знали б більше про розвиток мовлення"(37).

Фройд із “мовою снів” має на увазі промову, яка $\epsilon$ в грі у снах. I щоб промова була промовою, вона має бути артикульована, тобто відповідати певним значимим законам. Фройд пише також “розвиток мовлення”, маючи на увазі не тільки зміни у промові, а й мову як корінь, матриця, важливе ложе. 
Людське слово через оригінальне непорозуміння $\epsilon$ структурованим фундаментальним парадоксом: 3 однієї сторони мордує людину, роблячи іï хворою; з іншої сторони лікує. Ось в такий спосіб Фройд представляє слово, і якраз в цьому вимірі він працює з ним зі своїми пацієнтами.

Знаменита «talking cure», яка вислизнула з язика Анни О., дає нам зрозуміти міру прихованої правди в слові, яка одного разу виринувши на поверхню, виліковує суб'єкта від симптомів, які приносять страждання.

В такий спосіб Фройд відкриває область співзалежностей стосунків людини із символічним порядком, відновлюючи слову його цінність, його складність, щоб залишити у спадщину те, що можна сказати ось так: людина хвора словом. I власне незнання або не пам'ятання цього пункту приводять до забуття цього відкриття Фройда.

У семінарі з “Психозу" Лакан говоритиме, що слово $\epsilon$ найціннішим об'єктом обміну. І справді ми не робимо нічого іншого, ніж обмінюватися словами. Тому на перший план ми ставимо відношення мовця до мови тому, що людина має реагувати не тільки на подразники навколишнього середовища, але й передусім на всесвіт значень:

“Людина говорить, (каже Лакан), але тільки тому, що символ зробив із неї людину”(38).

\section{СПРАВЖНІ ІНСТРУМЕНТ ЦЕ СЛОВО}

Повертаючись до ідеї про домінування науки в часи коронавірусу i анатомію слова, яке будує людина за своїм образом та подобою, і стартуючи з назви мого першого виступу "Психоаналіз та психотерапія”, ми можемо сказати, що як одне так i інше націлені на світ символів, який засновує слово. Будьяка форма психотерапії в напрямку психоаналізу не може не брати до уваги цей базовий вимір: ми зроблені із слів і маємо справу із непоправним непорозумінням. $€$ багато авторів, які доклали багато зусиль для того щоб розрізняти психоаналіз та 
психотерапію, ставлячи психоаналіз на перше місце, обезцінюючи Я на користь позасвідомого. Але будь-яка форма переваги $\epsilon$ нічим іншим, як наслідок нарцисизму. Також тому, що психоаналіз перед різними формами психотерапії представляється як ресурс, яким варто користуватись. Психоаналіз це практика без правил, але не без принципів. I його принципи це принципи позасвідомого, що беруть до уваги Я.

Для Фройда, Я - це область свідомості та сприйняття. Нарцисизм та Его, які $\epsilon$ його складовими частинами, $\epsilon$ фундаментальними для суб'єкта. Тому нема суб'єкта без цих основних складників для людської суб'єктності.

У Джойс і в маленькому “Дік делла» Кляйн, ми маємо приклад наслідків з вини Его.

Я має уявну структуру, але незважаючи на це воно має не менше значення. 3 іншої сторони для Лакана уявне, як регістр людського досвіду, разом з реальним та символічним відіграє важливу роль.

Фройд говорить про Ідеал я і Я ідеальне, важливі стовпи, навколо який крутиться аналіз: "Wo Es war, soll Ich werden" "Де було Воно, має прийти Я". Коли Фройд говорив про ідентифікацію дитини з батьками, він мав на увазі всю послідовність ідентифікацій, які будуватимуть його я. Навіть я Дори $\epsilon$ частиною цього, починаючи ідентифікацію з батьком.

У своєму тексті “Промова про психічну випадковість”(39), Лакан нам повідомляє про Я як матрицю, ложе для ідентифікації. Всю цю справу, яка стосується відторгнення, нашого відношення до формуючих ідентифікацій, які $\epsilon$ важливими для доступу до бажання Іншого, ми вирішуємо тут: в області Я як формуючому елементі уявного ставлення (40). I Лакан каже у такий спосіб “Для того щоб були стосунки з об'єктом, треба щоб існували стосунки Я з іншим”(41). 
У метафорі про цибулю, ми наближаємося до цього виміру Я як ложе для ідентифікації. Я як цибуля, яка складається 3 багатьох шарів.

“Я (каже Лакан) є об'єктом подібним до цибулі, можна було 6 почистити його і можливо знайти наступні ідентифікації, з яких воно складається (42).

Так позасвідоме не анулює я, але бере його до уваги у зв'язку з походженням, яке $\epsilon$ викоріненим: я не $\epsilon$ головним у своїй хаті. Сучасний суб'єкт має потребу бути підтриманим у цьому вразливому пункті для нього, перед тим як почати демонтувати те, з чого він побудований і що зараз його приречує на покидання свого бажання.

На початку пандемії, один мужчина 44 років зв'язався зі мною із Швейцарії, бо впав в депресію у зв'язку із любовними стосунками. Він одружений багато років, але дружина зійшлась з іншим мужчиною та попросила його покинути дім. Він погоджується і вирішує поселитися в готелі, поки не знайде інше місце для життя. Під час своїх сеансів, через Skype він зв'язується з різних місць: з машини під час водіння, або навіть з парку в той час, як їсть бутерброд. Постійно питає мене чи це не представляє для мене труднощі. Я відповідаю, що це $\epsilon$ місце слова і в той же час наголошую на важливості гарантувати місце, в якому може протікати слово без великих перешкод. 3 наступного разу і до моменту, як він знайде інше помешкання він контактуватиме зі мною із закутка Церкви близько його роботи.

Цей добрий від природи чоловік $\epsilon$ прикладом християнської любові, тобто жертвує самого себе заради щастя іншого. В одному із сеансів виплив спогад, який вплинув на його ставлення до протилежної статі.

У віці 8 років він був свідком сцени, в якій дівчина, яка йому подобалась, пішла собі з іншим хлопчиком, красивішим за нього. I з цього моменту краса іншого, його перевага, дають форму його самотності, його відмови від свого бажання на 
користь своєї насолоди. Дружина є закохана у їі керівника і це слово «керівник» $\epsilon$ всім тим, що необхідно для нього, щоб стати солдатиком своїх фантазмів. І кожний раз, як він вимовляє це слово, він сміється, не звертаючи уваги на сором, написаний на його обличчі.

На екрані $\epsilon$ тіло у своїй спектральній формі, але те що не залишається спектральним - це голос та погляд, два основних об'єкти нашої клініки. Слово не є повністю анульованим і тому не $\epsilon$ анульована можливість перенесення. Прикладом $\epsilon$ також факт, що після року роботи та викриття цього способу відмовитись від самого себе, він вирішує приїжджати у Мілан раз на тиждень, для того щоб продовжити аналіз, який можна назвати справжнім.

Це $€$ свідченням випадку неврозу, в якому також можна також зробити дірку в екрані, розбивши його, щоб відновити об'єкту його гідність через присутність тіл.

Для деяких психічних суб'єктів може бути корисним проводити віртуальні сесії, що може мати для них заспокійливий ефект.

Говорю для деяких з них, щоб не узагальнювати, бо для нас залишається принцип від випадку до випадку.

В цьому році пандемії відбулось багато речей в нашій клініці, багато трансформацій, які випробовували психоаналіз, але в той же час потребували роботи нашої клініки. I навіть відновили важливість у сучасному суспільстві.

Я говорив про науку та швидко торкнувся релігії, майже як благочинності, щоб сказати потім, що ми займаємось реальним тобто, що не йде добре у нашій цивілізації. І для того, щоб мати можливість читати на 360 градусів ми не можемо ігнорувати нові виклики, які вона представляє.

Персони приходять до нас тому, що їхні символічні ресурси, щоб боротись із болем існування, до життя і до своїх постійних випадків вичерпались. Звідси народжується моя друга частина мого виступу «між реальним та віртуальним, справжній 
інструмент - це слово», що означає, що між реальним та віртуальним треба ввести символічне, єдине, яке дає можливість стосункам між статями.

\section{Література:}

1 Il seminario. Libro XXIII, II Sinthomo [1975-1976], Casa Editrice Astrolabio, 2 Jacques Lacan, II seminario. Libro XXIII, II Sinthomo [1975-1976], Casa Editrice Astrolabio, p. 130.

3 Ray Kurzweill, La singolarità è vicina, Maggioli S.p.A., 2014.

4 Olaf Stapledon, Il costruttore di stelle, Landscape books 2021.

5 Michio Kaku, Il futuro dell'umanità, Mondadori libro S.p.A., 2018.

6 Michael de Montaigne, Saggi, Giunti Editore S.p.A./Bompiani, 2017.

7 Jacques Lacan, Il seminario. Libro VII, L'etica della psicoanalisi [1959-1960],

Einaudi editori, Torino 2008, p. 274.

8 Jacques Lacan, Scritti Volume I, Giulio Einaudi Editore s.p.a, Torino 2002.

9 Sigmund Freud, Opere, vol. 11, Perchè la guerra?, Bollati Boringhieri Editori, Torino 1989 , p.290 - 303.

10 Ivi, p.299.

11 Sigmund Freud, Opere 10, L'avvenire di un'illusione, Bollati Boringhieri, Torino 1989, pp. 435-485.

12 Sandor Ferenczi, Opere, Anatole France, psicoanalista, pp. 120-127.

13 Anatole France, La rivolta degli angeli, Lindau s.r.l., 2017, Torino.

14 Sigmund Freud,Opere 10, Inibizione, sintomo e angoscia e altri scritti (19241929), Bollati Boringhieri, Torino 1989, p 448.

15 Sigmund Freud, Opere 10, L'avvenire di un'illusione, Bollati Boringhieri, Torino 1989, pp. 435-485.

16 Jacques Lacan, Il seminario Libro VII, L'etica della psicoanalisi (1959-1960), Einaudi editori, Torino 2008, p. 377.

17 Intervista rilasciata da Jacques Lacan a Emilia Granzotto pubblicata su Panorama, Roma, 21 novembre 1974.

18 Sigmund Freud, Opere 10, Inibizione, sintomo e angoscia e altri scritti (19241929), Bollati Boringhieri, Torino 1989, p. 630.

19 Rudolf Steiner, Le opere scientifiche di Goethe, CdL editore.

20 Francoise Dolto, Solitudine felice, Arnoldo Mondadori Editore S.p.A., Milano 1996, p. 380.

21 Orwell, 1984, Oscar Mondadori Editore.

22 Sigmund Freud, Opere, Vol. II, Progetto di una psicologia per neurologi, Editore boringhieri s.p.a., Torino, 1989.

23 Gustave Flaubert, Madame Bouvery, Mondadori libri S.p.A, Milano 2016. 
24 Robert Burns, The COMPLETE POEMS and SONGS, The Gresham Publishing Company Ltd, 2011.

25 Taras Shevchenco, Zapovit

26 Jacques Lacan, Seminario XXV, Il momento di concludere, Inedito.

27 Jacques Lacan, Scritti Vol. 1, Funzione e campo della parola e del linguaggio, Giulio Einaudi Editore s.p.a, Torino 2002, pp. 230 - 316.

28 James Joyce, Dedalus, Ritratto dell'artista da giovane, Adelphi Edizioni, Milano 2009.

29 Ivi, p. 178.

30 James Joyce, Il carteggio del più grande scrittore del Novecento, PGRECO EDIZIONI, Milano 2012, p. 54.

31 Jacques Lacan, Il seminario, Libro XXIII, II Sinthomo (1975-1976), Casa Editrice Astrolabio, Roma 2006, p. 91.

32 Sigmund Freud, Opere Vol.1, Trattamento psichico (trattamento dell'anima), Bollati Boringhieri editore s.r.l., Torino 1989 pp. 93 - 111.

33 Sigmund Freud, Opere Vol.1, Trattamento psichico (trattamento dell'anima), Bollati Boringhieri editore s.r.l., Torino 1989 pp. 93 - 111.

34 Franz Alexander, Medicina psicosomatica, Stabilimenti grafici Bemporad Marzocco, Firenze 1972.

35 Sigmund Freud, Vol. 3, L'interpretazione dei sogni, Editore Bolati Boringhieri s.p.a., Torino, 1989.

36 Sami - Ali, El impasse relacional, Temporalidad y cancer, Editorial Sintesis, S.A., 2000.

37 Sigmund Freud, Psicoanalisi della società moderna, Newton Compton editori s.r.l. 2007, p.58.

38 Jacques Lacan, Scritti Volume I, Giulio Einaudi Editore s.p.a, Torino 2002, p.269.

39 Ivi, pp. 143-187.

40 Jacques Lacan, Il seminario. Libro I, Gli scritti tecnici di Freud (1953-1954), Einaudi editori, Torino, 2014.

41 Jacques Lacan, Il seminario. Libro II, L'io nella teoria di Freud e nella tecnica della psicoanalisi [1954-1955], Einaudi editori, Torino 2006, p. 110.

42 Jacques Lacan, Il seminario. Libro I, Gli scritti tecnici di Freud (1953-1954), Einaudi editori, Torino, 2014, p. 203. 
DOI

\section{Элина Евланова}

Кандидат психологических наук, консультант психоаналитической ориентации, магистр клинической психологии и терапевтической медиации Университета Ниццы София-Антиполис,

Преподаватель Института профессиональной супервизии, Член и эксперт по сертификации образовательных программ Дивизиона “Психоаналитическая психология и психотерапия" Национальной психологической ассоциации Украины https://orcid.org/0000-0002-5418-7697

\section{ПСИХОАНАЛИЗ ОНЛАЙН: БУДКА СУФЛЕРА ИЛИ ВТОРАЯ СЦЕНА?}

Дорогие участники Конференции, вот наконец случилось то, о чем мы столько мечтали и говорили в течение последних полутора лет: мы вновь имеем возможность обменяться своими мыслями и чувствами глядя не в стекло экрана, но в глаза другому, в реальном телесном со-присутствии или face to face. И о чем же мы говорим, находясь в этом зале на расстоянии нескольких шагов друг от друга? Мы говорим про «Психоаналіз і віртуальне: етика, метапсихологія і клінічний досвід позакабінетної практики». Мы говорим о не-присутствующем. Пожалуй, сегодня остается лишь признать, что реальность сама очень четко обозначила те принципы, на которых всегда основывался психоанализ, поименовав нашу практику: психоанализ всегда не весь.

Мы не первое поколение психоаналитиков, которым приходится пересматривать устои собственной практики, вследствие социальных процессов. Возможно я несколько преувеличиваю, но таких глобальных изменений в мире, которые заставили бы психоаналитиков столь много размышлять и о клинике, и о 
метапсихологии и об этике нашего ремесла, общество не знало со времен второй мировой войны. Я имею в виду то, что сегодня порядок мироустройства стремительно преобразовывается, отражаясь на образе жизни жителей всех континентов нашей планеты, затрагивая основы профессиональной практики людей абсолютного большинства профессий.

Тревога, которая совершенно очевидно возникает у специалиста в ситуации неопределенности, является маркером и двигателем нашего желания. Чем больше мы слышим «психоанализ он-лайн невозможен», тем сильнее желание узнать, какой же он, психоанализ он-лайн. Если находиться на позиции, что это нечто виртуальное, тогда мы сталкиваемся с изменением способа, то есть того, что принято называть техникой процесса. Но, возможно, мы говорим лишь о новом означающем места?

Bupmyальное. Это одно из означающих, а возможно, и Господское означающее дня сегодняшнего. Оно пытается пристегнуть все новые и новые означаемые нашей эпохи. Какие бы сопротивления не встречало виртуальное на своем пути, каждый из нас в какой-то момент оказывается перед фактом того, что вынужден принять виртуальность очередного элемента реальности. Самое привычное и традиционное - потертые семейные фотоальбомы, шуршащие странички книг, шахматные фигуры так удобно укладывающиеся в руку, привезенные из отпуска ракушки с шумом морского прибоя, деньги и даже свидетельства, удостоверяющие нашу личность - все это недавно, но основательно переместилось в наши гаджеты.

Однако, если обратиться к этимологии слова «виртуальное», то мы увидим, что своими корнями это слово восходит к индоевропейскому праязыку. А точнее, в латинском мы находим корень vir (с лат. - «мужчина»). Римляне образовали от него другое слово - virtus, которое использовали для обозначения совокупности всех превосходных качеств, присущих мужчинам (физическая сила, доблестное поведение, моральное 
достоинство). Такое же имя было у богини Виртус из древнеримской мифологии. Ви́ртус (от лат. Virtus - Доблесть) или Виртута - спутница Марса, вдохновлявшая римлян на боевые подвиги ради отечества.

Из латинского слово проникает в старофранцузский, а в XIII веке - из французского в английский. В английском слово virtual c появлением вычислительной техники приобрело дополнительный оттенок «не существующий в действительности, но появляющийся благодаря программному обеспечению».

«Толковый словарь русского языка» под редакцией Д. Н. Ушакова (1935-1940) предлагает нам четыре варианта употребления этого слова.

\section{ВИРТУА́ЛЬНЫЙ}

1. В философии - существующий при определенных условиях и исчезающий при исчезновении этих условий.

2. Разговорный вариант - воображаемый, не реальный

3. Компьютерный - реализованный программно, симулированный, имитированный с помощью компьютера

Наиболее же, на мой взгляд, интересно значение слова «виртуальный» в специализированной лексике, то есть в профессиональной терминологии. Вот что, к примеру, пишет некий А. фон Вендрих, в книге «Записки эксплуатации железных дорог с военными целями. Курс старшего класса Николаевской инженерной академии.», 1886 г.: «Виртуальная длина есть такая воображаемая длина дороги, на которой поезд может следовать с постоянной скоростью.» В этом значении мы обнаруживаем смысл: «виртуальный то же, что эффективный, заменяющий реальный параметр в упрощённой модели».

Итак, мы можем лишь констатировать, что виртуальное абсолютно реально и эффективно переселилось из древних времен в новейшее время.

Под влиянием информационных технологий термин «виртуальность» приобрёл новое значение, связанное с виртуальной 
реальностью. «Виртуальность» в этом случае понимается как некоторое состояние, при котором субъект теряет различие между реальным и сконструированным (виртуальным) миром. В этом смысле «виртуальность» оказывается характеристикой сознания и восприятия субъекта. Такое понимание виртуальности применяется также в психологии, эстетике и культуре вообще.

Если мы позволим себе пойти дальше психологии восприятия и сознания, а именно этим и занимается глубинная психология и психоанализ, исследуя Бессознательное, то нам останется лишь констатировать, сколько виртуальности мы обнаруживаем в психоаналитическом дискурсе. По сути, наша реальность - психическая и никакая иная и есть та виртуальность, которую субъект конструирует на протяжении своей истории, в которой живет, любит, страдает, сражается, сопротивляется и повторяется на каждом этапе своей биографии.

И не случайно, что Фрейд называет Бессознательное второй сценой. Театр ведь абсолютно виртуален. Что такое театр, если не Виртуа́льность (лат. virtualis - возможный) - воображаемые объект или состояние, которые реально не существуют, но могут возникнуть при определенных условиях. Так или иначе представления, которые разыгрываются в аналитическом пространстве в страстном требовании быть услышанными и столь же страстном смещении-бегстве в симптом - это всегда пьеса.

Виртуальным является и чеховское ружье - объект, который помещается на стену и самим этим уже структурирует дальнейший ход событий.

Именно виртуальность и отличает Лакановский подход к языку от соотношения между означаемым и означающим, которое фиксирует Фердинанд де Соссюр. Концепция, основанная на том, что возможно найти «правильные означающие» и тогда можно все сказать, все выссказать разделяется филологами, когнитивистами и идеологами. 
Признавая то, что важным является само означающее, что всегда будет неудача в означивании того, что мы хотели сказать, мы признаем то, что в любом случае, нам не удастся все понять, мы признаем, то, что нам не удастся и истину высказать. Мы признаем себя на стороне психоанализа.

В своей статье «Психоанализ имеет структуру фикции» Жак-Ален Миллер пишет: «Истина имеет структуру фикции. Истина - это субстанция аналитического опыта, я бы сказал, его хлеб, то, что он порождает. Это держится только за счет того, что случаются разоблачения, озарения, моменты видения, то, что англичане называют инсайтом. По сравнению с истинами, о которых мечтал Декарт, отталкиваясь от от математики, - а на уровне матемы можно быть уверенным в том, что существуют вечные истины, - истины, порождаемые аналитическим опытом смертны, они относятся к уровню патем, к тому, что ощущается, то имеет отношение к патетическим истинам, поскольку патема имеет тот же корень, что и патология, (страдание, боль), патетика и т.д. Именно на этом уровне они многообразны, что и привело Лакана к изобретению неологизма «варите» (varité), множественной истины (от вериme verité - истина и вариабл variable - множественная). Порой, именно из-за усталости от обретенной истины, может появиться желание поменять аналитика - тогда обращаются к кому-то другому, объясняя себе, что идут за другой истиной.

Фикция, что это значит? Это то, что фабрикуют, что не относится к порядку природы, к греческому physis, но к poiesis, к продукту, к созданию. Фикция - это продукт, маркированный кажимостью».

В русском языке мы тоже находим подобную оппозицию. Именем нарицательным стали «физики» и «лирики» времен хрущевской оттепели 50-х, 60-х годов прошлого века. Это не только о формулах или стихах. Это и об этическом выборе и об отношении позиций понимания речи и языка к истине. 
Виртуальность пациента - в его речи. Пациент приходит в кабинет, наполненный событиями собственной жизни, которые он переселяет, переносит в то пространство, которому еще только предстоит быть созданным. Виртуальность аналитика в том, чтобы своей речью и ее отсутствием создать из психической аморфности сцену, на которой пациент сможет распознать способ своего наслаждения, сценарий со- существования с собственным телом, прочесть наибольшее количество фантазматических смещений.

Вспомним центральный симптом в переносных отношениях доктора Брейера и Анны О. - ее мнимую беременность. Вот что пишет наш коллега Юрий Вольных в статье «Синдром Кувада»: «Много лет спустя Йозеф Брейер рассказал Фрейду истинную причину прекращения лечения Берты Паппенгейм. «Вечером того дня, когда все ее симптомы были устранены, его вызвали к ней еще раз. И он нашел ее смущенной и корчащейся от спазмов в животе. На вопрос, что случилось, она ответила: «На свет родилось дитя доктора Брейера», придя в ужас, он обратился в бегство, передав пациентку своему коллеге.» В тот момент, говорит Фрейд, у Брейера в руках был ключ, однако, он не смог или не захотел им воспользоваться. Именно этот истерический симптом послужил Фрейду толчком для изобретения психоанализа и построения концепции переноса». Я бы добавила: именно способность Фрейда виртуализировать реальность, увидеть за телесным и словесным игру и позволила человечеству так приблизиться к пониманию психической природы человека.

Правила психоаналитического лечения, которые призваны структурировать и формализировать психоаналитическое пространство, обозначить место, где фикция сможет функционировать, сами по себе являются достаточно фиктивными в значении виртуальными. Мы говорим своим пациентам на первой встрече, что от них требуется приходить и уходить в определенное 
время, говорить все, что приходит в голову, не стараясь оценивать, как это прозвучит, оплачивать сессии, согласно договоренности. Однако мы прекрасно понимаем, что наша работа сможет состояться именно тогда, когда пациент совершает атаки на сеттинг, опаздывает или забывает прийти, перезвонить. Свободные ассоциации нам нужны для того, чтобы сконструировать нечто, о чем анализант «никогда так не думал», а оговорка всегда интимнее самого интимного признания. Невротик навязчивости скажет свою истину, с облегчением оплачивая пропущенные сессии, а истерик расскажет о детских фантазиях своим телом.

Размышления о том, что же происходит с аналитическим процессом, когда аналитическая ситуация переносится в виртуальное пространство в реальности, ощущение тавтологичности явлений привело меня к поиску фразиологизмов со словом «виртуальный». Полисемичность этого понятия оказалась столь очевидной во всех языках, и столь разнообразной для различных эпох, что его можно назвать не только господским означающим нашей эпохи но и метафорой синхронии и диахронии языка, и метафорой психоаналитического процесса.

Я уже упоминала о том, что vir в переводе с латинского означает «мужчина», а Римляне образовали от него другое слово - virtus, которое использовали для обозначения совокупности всех превосходных, идеальных качеств, присущих мужчинам (физическая сила, доблестное поведение, моральное достоинство). Более того, Vir perfectissimus (с лат. - «превосходнейший муж») - один из позднеримских титулов, присваивавшийся представителям исчезавшего сословия всадников.

Что маркирует тревога психоаналитиков при слове «виртуальный психоанализ»? Когда я слышу переживания по поводу того, что мы впускаем пациентов в свой дом, или, наоборот, что во время сессии оказываемся в комнате пациента, я слышу лишь структуру детского желания и приближения к объекту а. 
Для психоаналитическая сессия вписывается в ряды, означающие ни что иное, как «heimlich» - уютное и ужасное, для кого-то это отражает фантазии о проникновении.

А, возможно, тревога коллег при слове «виртуальный психоанализ» оживляет эдипальную ситуацию с сиблингами? Чем больше уверенность современных психоаналитиков и целых профессиональных организаций в том, что именно их миссия быть кронпринцами психоанализа Фрейда, тем ярче проявления тревоги. Возможно, моя догадка есть подтверждение лакановского постулата о том, что в нашей психике живут все значения слова, и что лишь раздев слово до «латинского платья» мы сможем понять, что же оно значит для жизни отдельно взятого человека.

Безусловно, мы не вправе отбрасывать нарциссический аспект, которым окрашен наш период, когда мы живем «от локдауна к локдауну», порой не имея возможности прогуляться по любимым улочкам, имея в то же время возможность одновременно оказываться в двух разных комнатах, городах и странах. Для кого-то работа он-лайн - субъектная реализация любой ценой и при любых условиях. Для кого-то же, наоборот, субъектное бессилие реализовать себя. Попытка отвергнуть «законность» психоанализа вне кабинета это всегда позиция «против». Паранойяльность - о-позиция - проявляется в попытке поставить психоанализ в позицию жертвы наслаждения большого Другого - всесильного, который волен устраивать пандемии, объявлять локдауны полные и частичные, закрывать границы, принуждать к вакцинации, подсматривать за нами в нашем доме, далее мы можем поставить любое означающее. В паранойальной позиции субъект не бессилен, но он злоупотреблен силой другого, и этот другой и будет всегда виновен.

Психоаналитический дискурс отличается от всех иных видов дискурса именно структурой, которая изначально предполагает невозможность полной самореализации. 
Серж Лесур в своем выступлении на конгрессе «Родина», которое называлось «Единственная Родина - это изгнание в язык» сказал: «Для человеческого существа первая встреча с жизнью и отношениями с кем-то другим имеет двоякий аспект. С одной стороны, ребенок конструирует первое представление, обрабатывая заботу своей матери, и выстраивает для себя первую родину, где он может иметь место; с другой стороны, из-за повторения, он теряет часть своего представления. На самом деле, никакой опыт не может быть точно таким же, и каждое новое объектное представление всегда является новым, и первое ощущение никогда не восстанавливается, даже если опознается. Эта функция нехватки в конституировании человека всем хорошо известна, и также известно, что эта Реальная нехватка станет источником желания в воображаемом».

Я вновь думаю о виртуальности и психоанализе, когда обращаюсь к «Толкованию сновидений» Фрейда. Что есть сновидение, если не «существующий при определенных условиях и исчезающий при исчезновении этих условий» продукт психической деятельности?

Или возьмем, к примеру, такой неслучайный для нас случай Серея Панкеева. Различить в незнакомом Фрейду русском языке означающие-метки сексуальности, распознав их в рассказе об истории детства. Для этого нужно было совершить виртуальное путешествие, перенесясь в родовое имение под Одессой, где росли прекрасные ореховые деревья, одно из которых так ужаснуло маленького Сережу, что потом ему еще долгие годы «доставалось на орехи». Сконструировать и предложить пациенту его сценарий, его базовый фантазм что это, если не талантливейшее поименование чего-то «не существующего в действительности, но появляющегося благодаря программному обеспечению».

В семинарах 1966-67 годов «Логика фантазма» Жак Лакан придаст объекту маленькое а статус, который он назовет «конструирующий логику фантазма» и далее станет исследовать отношение логики фантазма к структуре означающего как такового. 
Tout est langage «Все есть язык» так называется одна из книг замечательной Франсуазы Дольто. А там, где есть место языку и есть место психоанализа. И для того, кто имел достаточно хороший опыт личного анализа, это аксиома.

Вообще же, разговоры о разделении на психоанализ как таковой и психоанализ он-лайн напомнили мне начало Интервью, данного Жаком Лаканом в 1974 году во время его пребывания в Риме миланскому еженедельнику Panorama.

- Профессор Лакан, мы слышим все чаще и чаще о кризисе психоанализа: ходят слухи, что Зигмунд Фрейд устарел, а современное общество обнаружило, что его доктрины более недостаточно, ни чтобы понимать человека, ни чтобы дать глубокую интерпретацию его отношения с окружающей средой и миром...

- Это небылицы. Во-первых, нет никакого кризиса. Он отсутствует. Психоанализ еще не достиг своих пределов, но напротив: еще многого предстоит достичь как в практике, так и в области доктрины. В психоанализе нет сиюсекундных решений, но только долгое и терпеливое исследование ответов на вопрос «почему».

Его доктрина поставила под вопрос истину - вопрос, который касается каждого лично. Ничего общего с кризисом. Я повторяю, мы далеки от [понимания] целей Фрейда. Это еще и потому, что его имя послужило тому, чтобы покрывать множество вещей, в числе которых были и девиации. Эпигоны не всегда верно следовали [фрейдовской] модели, что и создало путаницу.

В завершение хочу обратиться к названию своего доклада «Будка суфлера или вторая сцена». Это безусловно аллюзия с одним из определений, которое Фрейд дал Бессознательному. Будка суфлера же есть символ некой конструкции, которая предположительно всегда должна быть расположена в определенном месте у сцены. Однако, давайте зададимся вопросом, как часто каждый из нас выходя после театрального спектакля говорит: «Вот здорово, что суфлерская будка была оснащена по 
всем нормам строительной документации. Или по-фен-шуй. Или...» я полагаю, нужное означающее каждый укажет сам.

Для примера я хочу взять случай анализантки, с которой я проводила сессии и у себя дома, и в кабинете и по вайберу. В октябре 2019 ко мне обратилась девушка 26-ти лет. Она искала психологическую помощь по совету своего лечащего врача. Она испытывала недомогания, повышение температуры, боли в горле как при ангине, без симптомов, которые можно было бы определить как органические изменения. Результаты очередных лабораторных исследований вновь не дали врачу основания назначить ей медикаментозное лечение.

За три месяца до нашей первой сессии девушка похоронила маму, которая умерла от рака. За восемь лет до этого также от рака умер ее отец. Запросом к психологу было помочь найти причину повышения температуры. Такой беспомощности как в работе с этой пациенткой я, пожалуй, никогда не испытывала. Речи как таковой просто не было. Но, у меня было ощущение того, что и молчания не было тоже. Я задавала какие-то простые вопросы, она на них как-то отвечала, но если бы не мои записи-пометки, я не могла бы восстановить в памяти что-то из наших первых сессий. Была ли это депрессия или проявление традиции ее семьи, где не привыкли говорить о чувствах? Сейчас я думаю, что это было и то и другое, и базовый фантазм о возвращении в материнскую утробу. Я впервые встретилась с пациенткой, чья фантазия, казалось, находилась в зачаточном состоянии. Единственное, что было - это телесные симптомы. Тело языка говорило температурой, причину которой не могли найти в теле врачи, следовательно, для меня на уровне влечений речь шла о теле психическом. Повышение температуры происходило в одно и то же время. Это было время, когда пациентка звонила маме в больницу, справиться о ее здоровье. Умирать от не вовремя диагностированной болезни - был ее способ говорить о маме. 
В своих записях, датированных уже апрелем 2020 я нахожу пометку «свободнее ассоциирует, появился аффект страха». K этому же времени относятся ее первые высказывания описывающие эмоциональное состояние «напружена, знервована». Родной язык пациентки - украинский, и я стараюсь сопровождать ее сессии также на украинском языке, что дается мне не всегда свободно и в привычном для меня речевом темпе.

На сессии в мае уже нынешнего года я отмечаю свою необычную легкость говорения на украинском языке. Записываю это в примечаниях к сессии с тем, чтобы поразмышлять позднее. И в этой же сессии появляется на фоне рассказа о празднике Пасхи и Гробкив - поминальных дней, рассказ об одной беспокойной, очень заботливой родственнице, которая «мама через край». Очевидно, что на место пустоты-симптома пришло слово-идентификация покойной матери и с покойной матерью. Пришла метафора, а здесь уже возможно не только именование оплакиваемого, но и проявление агрессивных, в данном случае саркастически оформленных тенденций.

Для меня эта работа, которая длиться с октября 2019 года, выглядит единой историей. И разделяю я ее именно на этапы, которые обозначила так:

- октябрь 2019 - апрель 2020. Период с момента обращения и до появления в речи пациентки описания ее состояний;

- апрель 2020 - май 2021 - появление метафоры как проявление амбивалентности чувств к матери.

- теперешний этап, который можно было бы условно назвать «если не только страдание, то что еще нужно от меня этой маме-аналитику?»

Как видно из вышесказанного, я не связываю динамику психоаналитического процесса с местом, в котором проводится психоанализ. Я не фиксировала даты, когда мы работали в кабинете, я лишь знаю наверняка, что с началом осеннего локдауна, эта пациентка перешла на дистанционную работу, и сейчас мы продолжаем встречи он-лайн. 
DOI

\section{Наталія Наливайко}

Психоаналітикиня, тренінгова аналітикиня і супервізорка Європейської конфедерації психоаналітичних психотерапій (ЄКПП, Австрія). Магістерка гуманітарних наук зі спеціальності психоаналіз, клінічна психологія, психопатологія (Університет м. Страсбург, Франція). Членкиня ЄАП, УАП, УСП та Дивізіону “Психоаналітична психологія i психотерапія" Національної психологічної асоціації України https://orcid.org/0000-0001-7427-3157

\section{TPETIЙ (HЕ) ЗАЙВИЙ. МОНІТОР У ПСИХОАНАЛІТИЧНОМУ ПРОЦЕСІ}

- Мене чути? Ви мене бачите? А так? А зараз? Все в порядку? Розумію, що ці питання видаються дивними і недоречними до учасників, які фізично присутні і перебувають зі мною в одному фізичному просторі. Однак, думаю, що вони цілком виправдані у моєму зверненні до тих, хто зараз перебувають 3 нами в одному віртуальному просторі.

Отже, ми знаходимося в моменті, в якому паралельно відбуваються дві різних взаємодії.

Вочевидь щось надає цим взаємодіям ознаки різної.

I цим «чимось» що робить неприсутніх присутніми і дає можливість вступити з ними в діалог, $\epsilon$ монітор. Монітор, в свою чергу, $є$ об'єктом що матеріалізує віртуальне. Тобто створюється ситуація, при якій для того, щоб відбулась комунікація двох, ми змушені прикликати медіума - третього.

Пандемія зробила нам виклик і достеменно змінила життя, відкоригувавши новочасність на свій лад, і сформувала так звану «нову нормальність», де з'явилися дещо інші правила, етика і навіть протокол. Ізоляція спричинила перегляд засадничих підходів до деяких сфер життя, включаючи психоаналіз, 
що перейшов у віртуальний режим, де аналітик i аналізант більше не знаходяться в одному просторі, а мусять утримувати свій інтимний зв'язок через третього. «Третій у сексуальних стосунках між двома особами, де $\epsilon$ любов, - зайвий або стоїть на заваді», пише Фройд у «Невпокої в культурі». А чим стає третій - віртуальний медіум, диктат якого все більше захоплює психоаналітичний простір, у психоаналітичних стосунках між двома особами, які також наповнені любов'ю?

Наскільки він (не)зайвий або стоїть на заваді у психоаналітичних стосунках?

I найважливіше - як він ушкоджує сеттінг? Якщо ушкоджує...

Ушкоджений сеттінґ, стабільність якого вважається гарантією «правильного» психоаналізу, і який змушений був змінитися, щоб зберегти метод, виявився нашим найбільшим страхом. Проте сам Фройд розумів необхідність часових адаптивних змін і в 1922 році записав: «Психоаналіз - це не філософська система, заснована на строго певних фундаментальних поняттях ... Навпаки, він слідує фактам в своїй сфері діяльності, намагається вирішити нагальні проблеми в процесі спостереження, намацує, використовуючи досвід, завжди незавершений і такий, що бажає по-новому поглянути на свої теорії або змінити їх».

Тобто, Фройд передбачив, що психоаналіз, щоб відповідати викликам і завжди бути новочасним, мусить адаптуватися. Ось що ми знаходимо в його роботі «Невпокій в культурі»: «Успіх ніколи не забезпечений, він залежить від збігу багатьох моментів $i$, певно, ні від жодного іншого так, як від здатності психічної конституції пристосовувати своє функціонування до навколишнього світу...».

Тому основну частину свого короткого повідомлення ми присвятимо міркуванням з приводу впливу великого третього на сеттінґ, реакції аналізантів та аналітиків, перебігу аналізу, загрозам та перевагам. 
Також нашою метою $\epsilon$ спроба дослідити, чим $\epsilon$ монітор у психоаналітичній роботі: заслоном чи провідником, перешкоджає взаємодії чи навпаки - сприяє їй, чимось нагадуючи захисну маску, при якій комунікація хоч і неповна, (нечітко вимовлені і почуті слова і прихована нижня частина обличчя, що обрізає образ і не дає доступу до повного сприйняття), але все ж можлива?

У стосунках двох з'явився якийсь третій, представлений у вигляді екрану, що має різну назву (Skype, Viber, What's UP, Messenger i т.д.), тобто якийсь віртуальний третій, якому Dr. Irmgard Dettbarn у статті «Skype as the uncanny third» дає назву uncanny, що відсилає до аналогіï із фройдівським The uncanny - моторошним/дивним/надприродним.

\section{Короткі клінічні замальовки}

Моя аналізантка завмирає перед екраном, зовсім втративши можливість говорити. Вона дивиться у нього як у щось жахливе, і це видно з виразу її обличчя. Я відкриваюсь. «Воно втягує», - говорить дівчина. «Якось незвично говорити до ніщо».

Моя друга аналізантка, жінка старшого віку, у другий раунд карантину все ж таки зважується на одну сесію он-лайн. Ми вмикаємося. На екрані видно тільки верхню частину їі обличчя, так ніби дитина навшпиньки дивиться у вікно. «Якось холодно», - говорить вона і кутається. А потім вона, видно, що силується говорити щоб не образити мене, але жодних асоціацій не має. «Якось страшно. Нічого не получається» - закінчує вона сесію.

Моя ще інша аналізантка зовсім не хоче мати справу 3 «цим» і чекає закінчення карантину.

Інший признається, що цей дивний третій дає можливість приховати щось. Вибирати що показувати. Йому подобається говорити через когось. «Це - безпечно. Можна себе стримувати».

Аналізант наділяє монітор або те, що він уособлює, якоюсь надзвичайною всемогутністю, що або лякає його i виставляє заборону, або надає ті можливості, які неприпустимі в кабінеті. 
Але цей дивний третій диктатор не тільки для аналізанта: він часто визначає хід сесії.

Я чекаю аналізанта під комп'ютером. По зеленій крапочці біля аватарки я бачу, що він он-лайн, але дзвінка немає. Я знаю, що бувають поломки, і дзвоню я. Виявляється, він вже дзвонив, але я не відповіла, бо Skype «заглючило».

Машина, третя сторона, яка раптом визначає правила, стає частиною нашої роботи. Це впливає на нас обох: ми обоє не захищені від вторгнення. Ця третя сторона, яка не тільки бере участь у контакті Skype, але й визначає його в певній мірі.

Irmgard Dettbarn пов'язує цього «дивного третього» із перехідним об'єктом Віннікотта (1971) та особистим предметом Хабермаса (1999), які супроводжують нас у житті. Особисті предмети $\epsilon$ посередниками не лише між людиною і природою та між людиною та культурою, а також, по-третє, між людиною та їі ближніми, особливо його суттєвими іншими.

А) Особисті предмети можуть нагадувати нам про суттєвого іншого, а отже, стосунки з ним або навіть можуть представляти його. Особисті предмети допомагають символічно підтримувати зв'язок з іншим чи іншими; вони роблять його присутнім, навіть коли його більше немає після розлуки або в ситуаціях розлуки (Habermas, 1999, р. 500). Вони створюють зв'язок між живим і мертвим.

Б) Особисті предмети можуть також служити середовищем для зв'язку з іншими, діючи як спільний об'єкт, організовуючи спільну діяльність або роблячи можливим спілкування на великі відстані, тобто такі технології, як телефон та машина.

Пристрій, запрограмований на використання Skype, будь то комп'ютер, ноутбук або iPad, виконує ці функції особистих об'єктів. У своєму технічному існуванні він $\epsilon$ посередником між людиною та культурою, і коли використовується як засіб комунікації, він не тільки пов'язує аналітика з аналізатом та 
під час сесій, але може символічно встановити та потенційно підтримувати зв'язок вічно, так, коли учасник Skyре дивиться щоб перевірити, чи його аналітик цілодобово в мережі.

Улюблений предмет як би став живим, поселившись десь між живою та мертвою матерією. За аналогією із uncanny моторошним/дивним. Дивне те, що існує між життям і смертю і створює враження про життя.

Продовжуючи тему технічної недосконалості аналітичної роботи он-лайн, необхідно сказати й про те, що технічні труднощі із Skyре у кожному випадку відбуваються по-різному, залежно від того, чи був контекст негативним чи позитивним перенесенням.

Крім того, перерваний зв'язок - це перерваний зв'язок чи навмисне уникнення з боку аналізанта або аналітика?

Коли з'єднання не вдається під час сеансу Skype, це може бути незначною перешкодою для деяких людей. Однак для інших це може означати реактивацію травми, а може навіть спричинити травму із пов'язаними з нею почуттями безсилля, безпорадності та вразливості.

Клієнтка, колишня мешканка дитячого будинку, після того як перервався зв'язок, ділиться:

- Це жах якийсь. Тільки тебе понесло, відкрилась, а тут обривається... «Закрий рот, закрий рот!». Тільки і чую це знову. Блокуються емоції.

«Цьому однаково піддаються і аналітик, і аналізант: можливо, навіть існує ризик спокусливого симбіотичного «об'єӘнання сил» проти дивного третього», - говорить з цього приводу Dr. Irmgard Dettbarn.

Як інтерпретувати, наприклад, обмовку, яку чує аналітик з уст аналізанта - це продукт несвідомого чи брак зв'язку? Недочуте слово, перепитування - це знову брак комунікації чи навмисна дія аналізанта?

Якщо відсутній відеозв'язок, і ми працюємо тільки з голосом, як вловити дисонанс між сказаним і його тілесним проявом? 
Зміна інтонації/уповільнення/пришвидшення - це зміна в мовленні суб'єкта чи похибки інтернет з'єднання?

Що стосується голосу, то мовчання також $\epsilon$ частиною розмови. Неспокійна або несправна технологія унеможливлює виникнення будь-якої "чуттєвої тиші" (sence-perceptable) (Gehring, 2006, p. 91).

У кожному разі, Skyре ускладнює будь-яке “мовчазне розуміння". Якщо ні аналітик, ні аналізанд не говорять в Skype, ми не можемо сказати, чи мовчання пов'язане з технічною проблемою, чи це активна тиша з боку одного з нас. Це може призвести до небажаної ситуації "змушеного говоріння" для обох сторін. Поганий зв'язок з Інтернетом може спричинити спотворення голосу, так що він повторюється як луна.

Голос не може передавати жодного сенсу. Він не може ні реально «жити», ні «померти». Skуре повертає нас у дивовижний простір між життям та смертю.

Часом технічна несправність продукує шум, який чує тільки один із учасників. Наприклад, аналізант. Для аналітика може стати питання що все ж таки чує аналізант: голоси чи реальні технічні втручання?

Отже, використання онлайн-сесій достеменнно змінило стосунок психоаналітик - аналізант і, відповідно, підняло питання сеттінґу, асоціативної динаміки, використання опорів, аналіз перенесення-контрперенесення та інтерпретацій, що історично вважається головною передумовою тлумачення несвідомого в психоаналітичному кабінеті.

Нагадуємо, що сеттінґ регулює стосунки між аналітиком і аналізантом всередині психоаналітичного простору. Для класичного психоаналізу психоаналітичний сеттінґ включає в себе:

- для аналізованого - основне правило (говорити все, що приходить в голову),

- для аналітика - плаваюча увага, професійна таємниця, нейтралітет і стриманість, визначення кількості щотижневих 
сесій, розклад, оплата гонорару і форма оплати та кабінет психоаналітика, який вважається фізичним контейнером відносин і того, що в ньому повторюється, а отже - психоаналітичний контракт.

Роберт Ленгс (Langs, 1978) описує сеттінґ, або рамку, як психологічні кордони і узгоджені умови, в яких буде проходити терапія. Встановлення і підтримка надійної рамки «породжує довіру до терапевта і почуття безпеки, що сприяє повідомленням несвідомих фантазій пацієнта...».

Сеттінґ також $є$ контейнером для відреагувань (Біон), таким чином створюючи стосунки мати - дитина і може бути тим єдиним, в чому аналізант знаходить опору.

Визначальною характеристикою сеттінґу $є$ його стабільність.

Проте, заочні сесії, по телефону або по відеозв'язку ставлять під питання ці засадничі вимоги до психоаналітичного простору i, безумовно, припускають великі зміни в сеттінґу. «Сеттінг піддається впливам, що виходять із соціального оточення, в контексті якого протікає аналітична робота. Сеттінг повинен враховувати певні зовнішні обставини заради узгодженості між сеттінґом і соціальним оточенням, в контекст якого він поміщений. Зміни сеттінгу у відповідь на вимоги реальності, до якої він в кінцевому рахунку і належить, цілком виправдані» (Гораціо Етчегоен, 2020).

Перш за все, контакт між аналізованим і аналітиком є віртуальним, і в ньому не бере участь кабінет психоаналітика як контейнер і єдиний спільний простір.

Аналітик і аналізант позбавилися спільного простору. Натомість $€$ паралельні простори і кожен контролює простір, який показує. Так, наприклад, всі мої аналізанти відвідали мій домашній кабінет, а я побувала в їх кухнях, вітальнях, машинах, садочках, пляжах, часом - спальнях, познайомилася з їх собаками, котами, рибками, провела сесії під гучну вуличну музику, наслухалася пташок тощо. 
Крім того, може існувати іще кілька паралельних просторів у аналізанта і аналітика. Майже всі визнають, що під час он-лайн сесії $\epsilon$ спокуса для сторонніх активностей, або ці активності частково реалізуються.

Як наслідок - різні асоціативні ряди через перебування в різних просторах.

Наша тілесна присутність в принципі різна: не з'являється повний образ і, відповідно, немає мови тіла, ми не спостерігаємо спосіб, в який аналізант проходить, де сідає, як сідає, як себе репрезентує в одязі тощо. Натомість вся емоція концентрується у виразі обличчя або лише у голосі у випадку, якщо немає відеозв'язку. І якщо вилучено тіло, то що прийшло йому на заміну? Бо насправді деякі аналізанти демонструють значний прогрес в роботі позасвідомого в аналітичних сесіях онлайн.

У цій новій постановці аналізант проводить сеанс в своєму власному будинку або в кімнаті, тимчасово використовуваної для сесії, часто густо створюючи ту атмосферу, яка $є$ бажаною для нього, застосовуючи ті чи інші ритуали, які неможливі в реальному кабінеті. Наприклад, робочий кабінет одного із моїх аналізантів, з якого він працював в аналізі, був наповнений переспівом пташок, який я прийняла за реальний спів пташок за вікном. Насправді ж він просто включав запис, і був його ритуалом, що супроводжував сесію, а коли ми зустрічаємося в інший день, і він вдома, то він застосовує інший ритуал. Звичайно, що це хороший матеріал для аналізу, але факт залишається таким, що це аналізант, а не аналітик створює простір свого аналізу, роблячи його комфортним. Або інша моя пацієнтка за час карантину провела мене по всім кімнатам свого будинку, включаючи машину, кожного разу відшукуючи кращий інтернет.

Тут постає запитання чи відповідає комфорт вимогам аналітичного сеттінґу, який включає поняття фрустрації та абстиненції? 
Сеттінґ в принципі втратив ту форму, до якої ми звикли. I в першу черга зникла та асиметрія в аналітичному кабінеті, при якій домінуюча роль аналітика була беззаперечною.

Так, наприклад, аналізант і аналітик урівнялися в контролі над часом і над ситуацією. Кожен з них під тим чи іншим приводом може закінчити сесію. У звичайній психоаналітичній ситуації ця привілея належить переважно аналітику. Крім того, аналізант не витрачає часу на дорогу, і це багато чого йому заощаджує. Він має більше можливості розпоряджатися своїм часом.

Оскільки сеттінґ покликаний гарантувати почуття безпеки, то його першою необхідною і обов'язковою ознакою $є$ конфіденційність.

Один із моїх аналізантів після переходу в онлайн тепер кожного разу, коли починається сесія, переконується в тому, чи надійно працюють у нього навушники і навмисно фоном вмикає музику, щоб заглушити звуки свого голосу на випадок, якщо хтось сидить у приймальній. Тобто в умовах віртуального кабінету конфіденційність втратила свою надійність.

Під час сесії вона може порушуватися мимовільним втручанням інших осіб, інформаційними шумами, проблемами інтернет-контактування, паралельними відволікаючими активностями, зовнішніми звуками. Також існують можливість несанкціонованого запису, таємної присутності під час розмови сторонніх осіб, хакерство. Немалу роль грає непристосованість до домашніх умов аналітика і аналізанта. Багато хто переймається вибором надійної інтернет платформи.

В додаток до всього іншого робота у віртуальному сеттінґу в купі з обмеженнями пандемії і вимогами до дотримування соціальної дистанції може легко піддаватися маніпуляції: аналізант може в останню хвилину відмовитися приїхати в кабінет, а просити сесію он-лайн, посилаючись на нежить або інше недомагання, що раптом у нього/неї з'явилося. Аналітик вимушений приймати такі умови. 
Як нам відомо, основними принципами психоаналізу є згадування, відтворення, опрацювання, тобто в аналітичному кабінеті відбувається перепрожиття попереднього досвіду.

Як йшлося вище, кабінет психоаналітика $є$ фізичним контейнером відносин і того, що в ньому повторюється. На думку італійської психоаналітикині Бруні Марци для того, щоб говорити про повторення пережитого досвіду в віртуальному кабінеті, в психіці повинні бути зафіксовані сліди віртуальних випробувань задоволення / незадоволення настільки, щоб в подальшому, при аналогічній ситуації, людина могла їх пережити знову. Тобто так, щоб повторюваний цикл віртуального досвіду залишив свій слід, який суб'єкт міг би прожити знову в психотерапевтичному онлайн сеттінґу. В умовах відсутності стабільного психоаналітичного простору ці процеси, на мою думку, утруднюються. I потрібно покоління, щоб заклалася здатність до такої рефлексії.

В додаток до цього повтору перешкоджає часта зміна місця, в якому проходить сесія, що включає також вимушені часті переходи із звичайного кабінету в онлайн і потім знову в кабінет і тд.

Виникає питання, чи можуть перенесення та опір розвинутися в такій обстановці, достатній для того, щоб забезпечити справжній психоаналітичний процес.

Але зміна сеттінґа має не тільки руйнівний ефект. Зміна сеттінґа може надати терапевту унікальну можливість доступу до того, що раніше залишалося непоміченим. Інтерпретація цього досвіду допомагає відновити пацієнта і знову зафіксувати рамку.

Саме он-лайн режим дозволяє аналізанту сильніше виразити агресивні / сексуальні бажання, за які йому соромно, оскільки він/вона набагато менш замкнуті в онлайн-режимі.

Аналізант вільніше може розрядитися агресією в бік аналітика, аж до того що кинути смартфон або вимкнути аналітика із свого простору, як він вимикає себе із стосунків у щоденному 
житті, але в таких умовах не залишається часу для опрацювання цього матеріалу.

Он-лайн сеттінґ має ще й інші переваги: доступність, економія часу і грошей, вибір аналітика за критеріями кваліфікації, мови, культури, безперервність аналізу після зміни місця проживання, он-лайн сеттінґ дозволяє працювати з деякими критичними клієнтами, які уникають очних зустрічей. Крім того, аналітик бачить себе у маленькому моніторі комп'ютера, і це $є$ унікальна можливість подивитися на себе очима аналізанта.

Окремими пунктами в новій психоаналітичній нормальності виступають інтерпретації і кушетка.

І знову онлайн комунікація ставить багато запитань. Цього разу до інтерпретацій.

I, що врешті решт робити з кушеткою - символом психоаналізу?

Чи є тепер у неї місце?

Таким чином, сеттінг як умова психоаналітичної сесії втрачає свої традиційні обриси.

Ми повинні констатувати, що у сьогоднішньому світі все більше людей перебуває онлайн. Вже у 2011 році Вікіпедія повідомила, що через Skyре можна отримати доступ до 30 мільйонів користувачів, які одночасно були в мережі. Їх до цього примушує сучасний ритм життя - часті зміни у житті. Можна собі уявити, що сьогодні, у 2021 році, кількість он-лайн користувачів виросла в рази.

Такі змінені обставини нової нормальності ставлять питання, які вимагають від нас переосмислення традиційного поняття психоаналітичної сесії і відповіді на запитання чи стануть для нас нові форми психоаналізу новими можливостями?

Сподіваюся, що так, оскільки психоаналіз - теорія новочасності.

Адже ж «...nсихоаналіз, зародившись в лоні Новочасності i вилонившись з самих їі надр, нерозривно, структурно, 
іманентно пов'язаний з усіма головними та побічними їі сюжетами, колізіями, перипетіями і констеляціями, нерозривно зав'язаний на основні і другорядні ії вузли, нероздільно зрощений із нею в усіх їі магістральних й подекуди дуже заплутаних лініях і відгалуженнях» (Ю. Прохасько, 2021).

\section{Література:}

1. Журнал клинического психоанализа. Том II. No 1. 2021 Психоаналитическая психотерапия во время пандемии.

2. Прохасько, Ю. (2021). Психоаналіз як теорія новочасності. В 3. Фройд Невпокій в культурі. «Апріорі».

3. Фройд, 3. (2021) Невпокій в культурі. «Апріорі».

4. Фройд, 3. Дві статті в енциклопедії: «Психоаналіз» i «Теорія лібідо». Том 9.

5. Dettbarn, I. (2013) Skype as the uncanny third. In Psychoanalysis online. Mental Health, Teletherapy and Training. Karnac Books Ltd, London.

6. Gehring, P. (2006). The repeating voice. On the punishment of Echo. In: D. Kolesh \& S. Kramer. Voice. Frankfurt, Germany: Suhrkamp.

7. Freud, S. (1919). The uncanny. London: Hogarth.

8. Haberemans, T. (1999). Geliebte Objekte (Loved Objects). Frankfurt, Germany: Suhrkamp.

9. Winnicot, D.W. (1971). Playing and Reality. London: Tavistock Irmg

10. Преконгрес IX Всесвітнього конгресу по психотерапії «Психотерапія на допомогу громадянам, сім'ям, колективам, всьому суспільству під час пандемії, що викликана коронавірусом».

11. Марци, Б. Очні і заочні психоаналітичні сесії: відмінності і переваги [Електронний ресурс]. Доступ за посиланням: https: / / www.micropsicoanalisi.it/\%D0\%BE\%D1\%87\%D0\%BD\%D1\%8B\%D0\%B5\%D0\%B8-\%D0\%B7\%D0\%B0\%D0\%BE\%D1\%87\%D0\%BD\%D1\%8B\%D0\%B5\%D0\%BF\%D1\%81\%D0\%B8\%D1\%85\%D0\%BE\%D0\%B0\%D0\%BD\%D0\%B0\%D0\%BB\%D0\%B8 \%D1\%82\%D0\%B8\%D1\%87\%D0\%B5\%D1\%81\%D0\%BA\%D0\%B8\%D0\%B5\%D1\%81/?fbclid=IwAR3nmh_sjzGdQxDUHttpfjQQtRWRL13QU6GjqdiOR_rM96WIbp6ZmXKA0E 
DOI

\section{Елена Башмакова}

Ph.D., кандидат психологических наук, психоаналитик, преподаватель психоанализа, соавтор проекта “Лакан в Одессе" https://orcid.org/0000-0002-6311-0587

\section{AVE CORPUS SOLIDUM: ПРИСУТСТВИЕ И УКЛОНЧИВОСТЬ ТЕЛА В ПСИХОАНАЛИЗЕ Ж. ЛАКАНА}

\section{Пандемия - хватаемся за то, что отнимают}

Реальное коронавируса ворвалось в наше воображаемо безопасное существование с большой помпой, разрывая его на куски. Мы сможем понять смысл происходящего лишь тогда, когда придем к какому-то концу. Но в текущей ситуации вновь обнаруживается верность утверждения Фрейда об управлении и терапии как невозможных профессиях.

Во время заточения мы стали остро ощущать расстояние и отсутствие тел и понимать, что понятий близости, дистанции, границ недостаточно для объяснения присутствия. Привычные понятия - близко, далеко - наполняются новым смыслом, а новые фразеологизмы свидетельствуют о дискомфорте, связанном с наличием и последствиями взаимных отношений и связей с другим - внешним и непосредственно близким, интимным И экстимным:

- социальная дистанция

- blurring - размывание, отсутствие границы между частным и профессиональным

- FOMO (fear of missing out) - страх пропустить что-то в социальных сетях

- FOGO (fear of going out) - боязнь высунуть нос на улицу, что лишь кажется нюансом агорафобии [1]. 
Цифровые технологии глубоко внедряются в нашу жизнь, дабы восполнить отсутствие тел. Два неологизма стали частью общего языка, очерчивая этот эффект:

- presential - face-to-face, очный, присутственный

- distancial - дистанционный, удаленный.

Мы можем «видеть друг друга» без наличного присутствия, «слышать друг друга», не приближаясь. Однако в отсутствие тел, без их противостояния, присутствие становится еще более загадочным, но не менее необходимым. И виртуальные аналитические встречи лишь подтверждают, что анализ неотделим от определенного отношения к присутствующим телам. Отсутствие тел обнаруживает себя как fuyant (фюЯн) - как тело, которое уклоняется, ускользает, избегает, спасается.

Масштабы и организованность бегства тел «из плоти и крови» из психоаналитического пространства, а также стремление легитимировать этот процесс, вызывают тревогу и озабоченность. Не взываем ли мы к тому, что, рискуя вот-вот быть утраченным, приобретает особую ценность? «Не без тела», «Телесные эффекты языка», «Событие тела», «Тело в психоанализе», «Бессознательное и говорящее тело» - так артикулируется эта проблема на семинарах, конгрессах и конференциях последних лет.

О чьем теле, о каком теле идет речь? Кому и зачем необходимо его присутствие и наличие? Может ли анализ происходить без присутствия аналитика, без собрания органов? Лакановский анализ дает в этих вопросах четкие ориентиры, на пересечении которых, не без тревоги, а порой и ужаса, можно основать свой выбор.

Самому наивному наблюдателю очевидно, что в аналитических отношениях участвуют два плотных, осязаемых, тела, два corpora solidum - тело аналитика и тело анализанта. Более искушенный искатель не только учтет, но, вслед за Лаканом, провозгласит присутствие аналитического третьего - речи, 
языка, этого тонкого тела. Уже в Римской речи Лакан сказал: «Речь является даром языка, а язык вовсе не есть нечто нематериальное. Это тонкое тело, но все же тело» [2].

Если опереться на представление Лаканом дискурса аналитика, то можно уловить различие между психотерапией и психоанализом. Инструмент психотерапии - речь, слово, которое спрашивает, требует, отвечает. Искусство психотерапии умение уловить речь больного, отвечать словом, способным ее распутать, символизировать травму. Это измерение присутствует и в психоанализе, но анализ направлен за его пределы - к логике того, что вызывает јоuissance симптома, который заставляет человека страдать, а потому приводит его в анализ. Для того чтобы состоялся анализ, психоаналитик должен воплощать для анализанта реальное присутствие объекта, который является причиной повторения его симптома, то есть его бессознательного наслаждения.

Вторая отличительная особенность анализа - это его цель обнаружение субъектом истины отсутствия сексуальной связи, что на схеме аналитического дискурса может быть распознано как дизъюнкция неспособности, не-встреча истины агента и утраты анализанта, S1//S2.

Более или менее, с существенными потерями, усугубляющими дизъюнкцию невозможности а//\$, и в виртуальном анализе, как в психотерапии, тонкое тело, речь продолжает звучать и имеет свои структурные эффекты. Поэтому сейчас ближе к телу... телу анализанта - говорящему и говоримому, которое страдает, то есть наслаждается.

Субъект бессознательного, о котором преимущественно говорит Лакан в первой части своего пути, строго говоря, не имеет тела, поскольку, в отличие от самого загражденного субъекта, тело не возникает из «чистой логики». Имея онтологическое измерение, Субъект бессознательного не принадлежит к измерению онтики, он не является сущностью, у него 
нет определенных физических проявлений. Именно поэтому он обладает онтологическим измерением, о чем говорит Лакан на XI Семинаре [3].

Позднее учение Лакана начинается с фактического отказа от формулы «бессознательное возникает из чистой логики», которая, казалось, составляла основу его учения. Его заменяет другая мысль, которая не произносится однозначно, но формулируется Ж.-А. Миллером как «бессознательное возникает из говорящего тела» [4].

Таким образом, субъект бессознательного наделяется телом, и отныне Лакан называет его очень просто - l'homme, человек. Здесь важно подчеркнуть это понимание, обретенное на повороте учения Лакана. Во-первых, в отличие от субъекта, у человека есть тело. Во-вторых, это тело - говорящее тело. В-третьих, тело не говорит по собственной инициативе [4].

Человек всегда говорит своим телом. «Je parle avec mon corps», я говорю своим телом - сказал Лакан на XX семинаре [5]. Человек использует свое тело как инструмент, чтобы говорить. Само тело, очевидно, не является причиной говорения, но оно открывает дверь человеку, использующему его, чтобы говорить. Лакан часто ссылается на пассаж Аристотеля «О душе», где тот подчеркивает, что думает не душа, а скорее человек думает своей душой [5]. Точно так же человек говорит своим телом.

С другой стороны, проходя через тело, речь, в сою очередь, на него воздействует - в виде резонанса и эха, которые являются реальными. И в этом смысле, по утверждению Ж.-А. Миллера, «бессознательное и говорящее тело - одно и то же реальное» [4]. «Бессознательное» и «влечение» в понимании Фрейда имеют общее происхождение - это следы речи в теле, телесные эффекты языка.

Именно к этому говорящему и говоримому телу, обращает и даже принуждает аналитическая кушетка. Ж.-А. Миллер 
говорит о ней как о гардеробе, где снимают и складывают свое активное тело, и отказываются от воображаемого тела. На кушетке оказывается третье тело - рубище, вретище, мусор, который мы таскаем за собой, но который так нам дорог.

И далее, материализоваться на кушетке как брошенное, сломанное, убитое тело - значит ощутить себя телом, на котором паразитирует речь, слабым телом, больным болезнью всех говорящих, то есть стать чистым говорящим [6].

Отныне бессознательное, взыскуемое в анализе, - это не бессознательное чистой логики, дискурс Другого, а бессознательное чистого наслаждения, за которым закрепился лакановский неологизм parlêtre, говорящество. Концепция parlêtre основана на изначальной эквивалентности бессознательного и влечения. В отличие от фрейдовского бессознательного, принадлежащего к онтологическому и этическому порядку, parlêtre - это онтическая сущность, она обязательно имеет тело, поскольку без тела нет јоuissance [4].

Итак, чтобы иметь субъект, сначала нужно иметь тело. Так же, чтобы иметь јouissance, нужно тело [7]. Психоанализ придает большое значение телу субъекта, ибо анализ можно проводить только с телом. Именно оно в анализе ставится на карту - в форме причиняющего страдание симптома в начале, его упразднения в ходе анализа, и возвращения телу чего-то несказуемого в конце анализа.

Чтобы создать тело, нужна плоть (организм), язык и образ. Эти три измерения - реальное, символическое и воображаемое - связаны узлом Борромео, конституирующим субъекта.

Вброшенный в мир, лишенный инстинктов, человек вынужден изобретать свое отношение к объекту, неизбежно проходя через требование, через Другого языка. Его первичное наслаждение утрачено, его правдоподобной репрезентации не существует, остается лишь след неудовлетворенности, позволяющий предположить существование мифического 
наслаждения, о котором Лакан говорит как о запрещенном всем говорящим [8].

Через язык организм трансформируется в тело, чрезвычайно чувствительное к означающим и расщепленное влечением. Это говоримое тело, запутанное в сети означающих, которые могут заставить его заболеть или вернуть к здравию. По словам Лакана, означающее превращает тело в территорию, область или среду Другого [9].

Означающее убивает вещь, и эта смерть живого делает организм телом, отделенным от его наслаждения, которое, тем не менее, возвращается через влечение, которое не закрывается ни воображаемым, ни символическим.

Так, подобно расщеплению самого субъекта, тело оказывается разделенным на его означающую часть (Другого в языке) и часть в реальном - ту радикальную инаковость, которая оставляет тело не самоочевидным, непрозрачным, загадкой, тем, что в какие-то моменты может казаться странным и неуместным. Зоной расщепления тела остается влечение, которое закрыться не может [3]. Однако у обладателя такого тела (ибо, хотя человек мыслит себя как тело, но телом он не является, он тело имеет) - отчужденного в языке, то есть невротического, субъекта - есть почти непреодолимая проблема: он не может удовлетворить влечения непосредственно. Его судьбой, следствием его структурного выбора оказывается удовлетворение в неудовлетворенности или мучении себя, то есть jouissance симптома.

Именно через симптом как событие тела, равно, как и через образ, тело вступает в психоанализ [10]. Как событие тела симптом является исключением из устоявшейся формы социальных связей, поскольку в нем удовлетворение преобладает над означиванием. Как превратность влечения, в первую очередь сексуального, симптом - это маскировка тайны сексуальных отношений и отсутствия сексуальной связи. Собственно 
так Лакан формализует фрейдовский миф об Эдипе как о структурирующем запрете, влекущем утрату јouissance: «/l n'y a pas de rapport sexuel» [5].

Это не означает, что не существуют отношения желания и отношения любви. Эта формула имеет смысл только на уровне наслаждения «тела к телу», где никаких отношений не существует. Двое не могут стать одним, и потому мы об этом мечтаем. Человек всегда получает удовольствие один, и не только в постели, например, мы не можем ни с кем разделить нашу головную боль, а боль - это форма наслаждения.

В целом, хотя изначально и в повседневном языке симптом - это проблема, от которой страдающий субъект хотел бы избавиться (и это многократно появляется в терапевтических запросах), это скорее решение проблемы отсутствия сексуальных отношений. Это единственное решение, которое каждым человеком изобретается по-своему, ним нельзя поделиться, его невозможно передать другому. Симптом - это решение проблемы отсутствия отношений между полами, которое не является коллективным [10].

Итак, у анализируемого субъекта есть тело. Говорящее, говоримое и наслаждающееся. Другое тело, которое в анализе участвует, - тело аналитика. Оно, конечно, не аналогично телу анализанта. Но так же неоднородно и дискретно. Оно проходит через ряд метаморфоз, которые соотносятся с разными этапами анализа [11].

Так, Лакан настаивает, что на первых встречах «конфронтация тел» необходима и важна [7]. Встреча тел пациента и аналитика - это момент инаугурации под эгидой дискурса господина. Господин пациент приходит к рабу аналитику, чтобы через его знание, мастерство, ноу-хау получить свой объект наслаждения. Порожденные этой встречей аффекты, приятные ощущения, добрые чувства возникают в дискурсе господина на основе прецедентного права, привязаны к чему-то 
уже сказанному, ортодоксии. Это подталкивает пациента к работе, соблазняя его возможным прекращением субъективного разделения. Аффект, производимый такой встречей, Лакан определяет как телесный эффект означающего. Это аффект «между телом и дискурсом» - эффект не смысла, но наслаждения, специфичного для дискурса господина.

Однако иллюзия возможного исцеления, то есть преодоления субъективной и телесной нецелостности, обещанная дискурсом господина, будет сметена, как только посредством входа в перенос будет установлен дискурс аналитический.

Так, в движении «десубстантивации», происходит первая трансформация персоны аналитика в аналитическое тело. Она предполагает постепенное опустошение субстанции, дистанцию, отводящую от личности самого аналитика, и открывает путь для производства психоаналитического знания - через столкновение с тупиками и иллюзиями переноса. Если же воображаемое тело аналитика, в виде любых элементов среды (картины в приемной, запаха в кабинете, цвета ковра или прихода следующего пациента) вновь появится в ходе терапии, то это будет признаком переноса и указанием на сопротивление, поскольку, согласно пониманию Лакана, «сопротивление появляется на свет переносом вперед».

Следующий этап - вхождение в перенос - отмечен возникновением аналитика как большого Другого, субъекта предположительно знающего. Это стадия профанной реинтеграции тела. На этом этапе аналитика, сведенного к взгляду и слушанию, через которые пациент в некотором смысле завершает свой симптом, достаточно, чтобы поддержать его разоблачение. Присутствие тела аналитика остается для выполнения этой функции необходимым, хотя оно должно оставаться в некотором резерве, в частности, путем отвода от взгляда.

Аналитик представляет аналитическое тело, делает себя опорой, носителем предполагаемого знания, которое якобы 
можно извлечь из Другого во благо пациента. Но если в теории Фрейда тело аналитика является опорой известного (в частности переиздания родительских фигур), то в лакановском расширении оно становится опорой неизвестного, то есть бессознательного знания, которое аналитик вмещает лишь постольку, поскольку сам пациент его предоставил, поместил в него, но все же игнорирует. В таком случае присутствие аналитика само является проявлением бессознательного пациента [3].

«Быть опорой - значит только предполагаться» - говорит Лакан [7]. А кто предполагается, как не Бог, большой Другой тот, кто имеет тело, но не существует, а присутствие которого не может быть схвачено, кроме как тело [3]?

Итак, в начале переноса субъект предположительно знающий, опорой которого становится тело аналитика, является фигурой большого Другого. Как символическое тело большой Другой включает в себя тело аналитика [12]. С другой стороны, как местоблюститель, представитель, аватар большого Другого, аналитик должен собирать «в своем теле» то, что он слышит от анализанта, чтобы стать его «интерпретатором».

Следующее логическое движение, завершающее анализ, направлено на извлечение из аналитического тела материала, относимого на счет предполагаемого знания аналитика. Большой Другой должен быть разоблачен, с него нужно совлечь его тунику, дабы дать возможность увидеть то, что изначально было завуалировано, - объект $a$ [5].

Когда субъект предположительно знающий терпит крушение, остается объект а - продукт разреза, объект вне тела. Аналитик и его тело в его новом измерении - измерении реального.

Ж.-А. Миллер говорит, что объектом анализа является сам психоаналитик - тот, кто способен сделать себя специфическим объектом, который позволяет другому переживать себя в качестве субъекта. В присутствии этого объекта человек всту- 
пает в размытый мир, где он уступает свою объектность в пользу говорящего тела, то есть бессознательного, а плотным объектом остается психоаналитик [6]. Этимология слова «плотный» не вызывает сомнений: такой, в котором много плоти, вещества.

Речь в таком случае идет о «реальном присутствии» аналитика. Святой Фома Аквинский говорит о реальном присутствии тела Христа в Евхаристии как о субстанции, которая не зрима «телесным оком», не воспринимается ни чувствами, ни воображением, но может быть увидена и осмыслена как реальность существа. Кардинал Томмазо де Вио в контексте богословских споров XVI века писал: «Никто не настолько глуп, чтобы утверждать, что дух есть тело; но мы говорим, что в причастии тело Христово становится духовным. Оно даже присутствует в причастии как реальное тело, хотя не существует в модальности тела».

Лакан говорит о реальном присутствии, объясняя функцию символического фаллоса, большого Ф. Помимо репрезентации органа, за пределами любого представления или возможного означивания, Фаллос имеет статус знака. И этот знак - реальное присутствие, которое аналитик может воплотить во плоти и крови. На определенном этапе анализа в его теле размещены объекты (а) анализанта, он воплощает объектпричину его желания. Когда аналитик - это присутствие, то он является одновременно и объектом-причиной желания, опорой вопроса «Que vuoi?» (КевОи, Чего ты хочешь?), и объектом поддержкой јouissance влечения. Так, через реальное присутствие Лакан размещает аналитика в сессии как топологический объект, опору для реального как невозможного присутствия, воплощая который аналитик может интерпретировать желание субъекта и единичное событие јouissance его тела.

В каждом разрыве между означающими для субъекта открывается вопрос о желании Другого и возникает лишь знак 
желания, и ничего означиваемого. Таким образом, в анализе функция символического фаллоса, которую он выполняет в «своем месте», состоит в том, что он является реальным присутствием желания [13].

Итак, Фи символизирует реальное присутствие - одновременно отсутствие и присутствие, значение и выход за его пределы. Пустое присутствие - интервал между двумя означающими (S1 // S2), отсутствие связи между ними, которое неизбежно отсылает к невозможности сексуальных отношений как наслаждения «тело к телу». Связь между двумя полами может существовать только благодаря означающим бессознательного; тела совокупляются, потому что слова совокупляются в бессознательном, в языке. Это то, чем аналитик поделиться не может, но о чем может подать знак [13].

Так, воплощая объекты (а) и репрезентируя Фи, аналитик может поставить субъекта перед истиной психоанализа: сексуальных отношений не существует. По словам Ж.-А. Миллера, для этого недостаточно видеть друг друга и разговаривать друг с другом [6]. Для того чтобы пережить сексуальное неотношение (не-связь), необходимо совместное присутствие двух плотных тел.

Итак, практикуя этику психоанализа, аналитик переживает собственное убийство, не убивая нападающего, принимает страсти собственного тела (его метаморфозы и смену модальностей присутствия), соглашается стать отходом и излишком, затрагивающим «не-бытие». Вероятно, это необходимая плата за возможность возродить страсть быть аналитиком и снова занять это невозможное место.

Возвращаясь к практике психоанализа во времена диджитализации и в условиях ограничений коммуникации face-toface. Структура современного субъекта не изменилась, но, трудно не отметить изменений в его отношении к языку и jouissance. Субъект пост- и гипермодерна подвержен социаль- 
ным связям капиталистического дискурса - особого типа социальных связей, который Лакан определил как слияние технонауки с рынком. Он изобретает решения, чтобы сконструировать свою субъективность и выдержать свое существование, но также для того, чтобы возразить большому Другому или обозначить его аннулирование, как диктуется дискурсом капиталиста [10]. Как в этом может участвовать в этом психоанализ, как, каким ему быть?

Формулу дискурса капиталиста можно прочесть так: агент - расщепленный субъект \$, у которого на месте истины - неизвестный ему господин S1 безостановочно поглощает прибавочное наслаждение, объект (а) посредством знания S2. Возможна и такая интерпретация: отчужденный, не имеющий жизненных ориентиров субъект, технологически экипированный и ведомый просто поданым экспертным знанием, получает прибавочное наслаждение, почти не напрягаясь. Он потребляет его неограниченно и безостановочно, ибо такова воля его господина «Наслаждайся!»

Дискурс дает нам тело, о котором мы можем сказать «у меня есть тело», а также является своего рода попустительством телам и их јouissance. И современный человек, обнаруживая себя в социальной сети, а значит в капиталистическом дискурсе, оказывается в угрожающей зависимости от технонауки, которая не ставит и не отвечает на вопрос о смысле. С другой стороны, все фигуры, способные ограничить наслаждение, устранены; это то, что Лакан называет «форклюзией кастрации» со всеми вытекающими отсюда последствиями, в первую очередь - «отказ от всего, что связано с любовью» [6]. В обстоятельствах человек погружается в избыток јоuissance. Так движется современный нам мир, и это не хорошо и не плохо, это просто так есть.

Однако основания, ориентиры и задачи психоанализа, как мы понимаем, радикально иные. Дискурс истерика и аналитика 
не может быть выведен из дискурса капиталиста. Тогда возникает вопрос: не включаемся ли мы в дискурс капиталиста, позволяя плотному, осязаемому телу уклониться от встречи с другим телом в аналитической сессии? Не изменяем ли мы аналитическому дискурсу и желанию аналитика? Похоже, что да.

Времена и обстоятельства меняются, но пока мы живы, пока мы можем выбирать, мы должны приносить на сессию свое тело.

Ave corpora solidum!

\section{Литература:}

1. Lacaze-Paule C. La présence réelle et la fuyance du corps // https://www.lacan-universite.fr/wp-content/uploads/2020/09/ironik-42-

Habeas-corpus.pdf

2. Лакан, Ж. (1995). Функция и поле речи и языка в психоанализе. М.: Гнозис.

3. Лакан, Ж. (2004). Четыре основные понятия психоанализа (Семинары: Книга XI (1964)). Логос.

4. Miller, J. A. (2016). Habeas corpus. La Cause du désir, (3), 165-170.

5. Лакан, Ж. (2011). Семинары. Книга 20. Ещё. 1972-1973. М.: Гнозис/Логос, 142.

6. Miller, J.-A. (2000) Le divan. XX1 e siècle. Interview // https://www.liberation.fr/cahier-special/1999/07/03/le-divan-xx1-e-siecledemain-la-mondialisation-des-divans-vers-le-corps-portable-par-jacquesalain-m_2784

7. Lacan, J. (1971). Ou pire. Le savoir du psychanalyste. Le Séminaire livre XIX (1971-1972).

8. Лакан, Ж. (1997). Ниспровержение субъекта и диалектика желания в бессознательном у Фрейда. Инстанция буквы, или Судьба разума после Фрейда. М.

9. Lacan, J. (1968). De la psychanalyse dans ses rapports avec la réalité. Autres écrits.

10. Canellopoulos, L. (2010). The bodily event, jouissance and the (post) modern subject. Recherches en psychanalyse, (2), 321-328.

11. Blaquière, H. (2015). Le corps de l'analyste. Figures de la psychanalyse, (1), 149-157.

12. Lacan, J. (1970) Radiophonie. Scilicet 2/3, Paris, Seuil, pp. 55-99.

13. Лакан, Ж. (2019). Перенос (Семинары: Книга VIII (1960-1961)), Пер. с фр. / Перевод А. Черноглазова. М.: Издательство "Гнозис", Издательство "Логос". 432 с. 


\section{ЕTИКА \\ ПСИХОАНАЛІТИЧНОЇ РОБОТИ ОНЛАЙН}


DOI

\section{Яел Кеŭдiш (Yael Kadish)}

Ph.D., психоаналітик IPA та клінічний психолог, член та голова Комітету з членства Південноафриканської психоаналітичної асоціації (SAPA), співголова Етичного Дорадчого Комітету в SAPC

(Південноафриканській Психоаналітичній Конфедерачіi), головний клінічний психолог у спеціалізованій психіатричній лікарні імені Tara H. Moross в м. Йоханнесбург, має приватну психоаналітичну практику https://orcid.org/0000-0003-0567-2474

\section{ЕТИЧНІ ВИКЛИКИ ПСИХОАНАЛІТИЧНОЇ РОБОТИ ОНЛАЙН У БЕЗПРЕЦЕДЕНТНІ ЧАСИ ТА ПОЗА НИМИ}

\section{Вступ}

У цій роботі описано етичні виклики, з якими зустрічаються психоаналітичні терапевти, що працюють під час епідемії Covid-19 і не тільки, з акцентом на порушення рамок роботи.

Коли на початку 2020 року пов'язані з Covid-19 локдауни майже в кожній країні змусили спеціалістів піти з офісів, поле психотерапії миттєво змінилося. У той час як практикуючі терапевти досі справляються з наслідками пандемії, в тому числі з драматичним переходом на віртуальну терапевтичну роботу, психоаналітична література намагається йти нога в ногу зі змінами в нашій практиці та більш масштабними наслідками.

Зараз ми можемо відчувати, що крайня нагальність вже минула і в будь-якому випадку всі ці порушення були короткостроковими, що наша практика більш-менш стабілізувалася. Але розумно було б ідентифікувати можливість більш довгострокових наслідків для кожного з наших пацієнтів, для нашої практики та психоаналізу в цілому.

Я проілюструю свою доповідь прикладами з Південної Африки, деякі з яких $\epsilon$ прикладами з моєї практики клінічного 
психолога та психоаналітика Південноафриканської психоаналітичної асоціації, а інші - з моєї роботи Головним психологом у психіатричній клініці Тара, державній лікарні в Йоганнесбурзі.

Подивимось на наступний приклад. Я знаходжусь на віртуальній сесії з пацієнткою в аналізі. Пацієнтка нещодавно помила волосся, воно все ще вологе. На ній пухнаста піжама, і вона виглядає як постаріла дитина, а не як доросла жінка.

Вона трохи червоніє, пояснюючи, що тільки що приймала ванну та відчуває себе зручно в піжамі. Вона сподівається, що так можна. Ї̈̈ рум'янець дає мені зрозуміти, що тут присутні приховані бажання. Я вважаю, вона хоче, щоб я була люблячою матір'ю, яка висушить іiї волосся та вкладе іiї спати. Поки я думаю про це, моє ревері перериває інша думка. Я згадую, що на сесії я взута в свої зручні капці. Звісно, вона їх не бачить, але я про це знаю, і тепер це стає частиною мого контрперенесення. І пацієнтка, і я повели себе так, як би ніколи не сталося на очній зустрічі. Через те, що не тільки вона, але і я порушила норми, я вже не відчуваю такої свободи для інтерпретації і моментально втрачаю впевненість у їі валідності. Я розумію, що маю спочатку завершити тему мого власного провалу в дотриманні рамок, перш ніж відчую, що можу зробити інтерпретацію. Ці крихітні моменти дійсно заслуговують нашої уваги. Важливо повернутися до самих основ рамок, поміркувати про клінічне значення, етичні виклики, а також нові поточні відкриття.

\section{Рамки}

У 1952 році Маріон Мільнер вперше ввела ідею рамки, порівнюючи їі з рамкою в мистецтві. Вона написала "...часова та просторова рамка (також) розмежовує особливу реальність психоаналітичної сесії. У психоаналізі саме існування такої рамки уможливлює розвиток тієї креативної ілюзії, яку аналітики називають перенесенням (с. 183)." 
У 1967 році Хосе Блегер опублікував важливу роботу на цю тему, визначивши рамку як усі константи психоаналітичної ситуації. Рамка інкорпорує формальні згоди: фізичний простір сеттингу, фіксований час сесії та правила оплати. Усе це міститься в професійному контракті. Крім того, рамка поєднує в собі два аспекти ролі та техніки аналітика - по-перше, аналітичні стосунки та, по-друге, аспект техніки, що відноситься до підтримання рамки.

Розуміння рамок Блегером було повсюдною константою в психоаналітичній практиці. Ідіосинкратичні взаємодії пацієнта в межах та в протидії константам рамки потрібно вважати змінними. Більша частина роботи полягає в аналізуванні та інтерпретації цих змінних. Блегер вважав, що рамка глуха, вона репрезентує не-процес та слугує такою точкою, від якої відштовхується аналітичний процес. Рамка невидима до тих пір, поки пацієнт не намагається їй протидіяти у своїх вираженнях типових конфліктів, і в цей момент вона оживає та стає помітною - змінною, яку можна використовувати в роботі. Коли взаємодія стає зрозумілою та опрацьовується, рамка знову стає частиною фону.

Пандемія та пов'язані з нею локдауни похитнули рамки. Здається, що ті три аспекти рамки, які попередньо були константами, тимчасово стали змінними. По-перше, це постійність фізичного сеттингу; по-друге, це порушення здатності терапевтів підтримувати аналітичне відношення; і по-третє, це нездатність терапевта підтримувати рамку. Ми використовуватимемо ці фундаментальні ідеї для осмислення того, як пандемія збила з пантелику весь аналітичний проект та які довгострокові наслідки це може мати.

\section{Сеттинг та аналітичне ставлення}

Коли став розповсюджуватися Covid-19 та почали відбуватися раптові зміни, що суперечили нормальній психоаналітичній практиці, не було часу на жодні приготування, перш ніж 
ми почали діяти. Ми не могли виконувати нашу звичну роль у підтриманні рамок, а лише відповідали на наявну ситуацію, намагаючись вижити в тому, що здавалося судним днем. Дуже важко було підтримувати аналітичне ставлення, пацієнт та аналітик разом виживали, можливо, навіть були в параноїдношизоїдній позиції, як називає ії Кляйн.

Аналітичне ставлення було описано багатьма авторами, починаючи з Фройда та його "Техніки психоаналізу". Подальші ідеї про цю концепцію надійшли від Роя Шафера (), Роберта Ленгса та були описані в менш відомих роботах, консолідуючих усі попередні ідеї та написаних Гевіном Айві, вихідцем 3 Південної Африки.

У роботі Айві зазначається, що аналітичні стосунки складаються з таких компонентів: стриманості, нейтральності, генеративної невпевненості, рецептивності та рішучості в контрперенесенні. Коротко пройдемося цими компонентами.

Стриманість (абстиненція) означає, що спеціаліст має стримувати себе від будь-яких терапевтичних дій або відсутності дій, які задовольняють несвідомі фантазії пацієнта, утримуючи певну дистанцію між тим, що пацієнт хоче, та тим, що дає йому терапевт. Ця дистанція уможливлює виникнення придатного до аналізу перенесення.

Нейтральність тісно пов'язана зі стриманістю. Анна Фройд описала іï як внутрішній стан рівної віддаленості від Я, Воно та Супер-Его пацієнта. Мусить бути нейтральність щодо того, що пацієнт приносить, чого бажає, до його механізмів захисту та самокритики. Нейтральність - це дисциплінована відмова від занадто емоційних реакцій на матеріал пацієнта; вона таким чином залежить від здатності терапевта вести постійний внутрішній діалог, що дозволяє йому мислити про себе.

Генеративна невпевненість походить з рекомендації Фройда аналітикам підтримувати вільноплаваючу увагу. 3 точки зору Біона - це слухати без підключення пам'яті чи бажань. 
Генеративна невпевненість - це ставлення продуктивного дослідження, що контрастує з непродуктивною та невротичною впевненістю пацієнта.

Рецептивність у контрперенесенні була вперше описана Полою Хайманн, яка стверджує, що, окрім вільноплаваючої уваги аналітика, яка дозволяє слухати на багатьох рівнях, аналітик мусить також мати вільно збуджену емоційну чутливість, яка дозволяє йому слідувати за емоційними рухами та несвідомими фантазіями пацієнта.

I нарешті, рішучість, яка $€$ присвяченням себе підтримці аналітичного ставлення. Підтримання відкритості до невідомого на сесії вимагає хоробрості та відчуття віри в аналітичний процес.

Ми знаємо, що психоаналітична робота передбачає постійну передачу від одного іншому та навпаки, ритм, що дозволяє нам переживати порушення, за якими йде процес осмислення та відновлення. Це нормальні мінливості нашої роботи, постійна інтра- та інтер-персональна обробка, що характеризує міжперсональне перенесення-контрперенесення.

Саме рамки та аналітичні стосунки дозволяють нам занурюватися в психічну реальність i, таким чином, працювати аналітично. Якщо здатність мислити аналітично унеможливлюється через порушення рамки або стосунків, це напевно можна вважати етичною проблемою.

\section{Час пандемії}

Коли пов'язані з пандемією локдауни почалися майже в кожній країні світу, спеціалісти стали перед вибором з двох опцій - продовжити працювати онлайн або припинити роботу. Ми все ще дізнаємося, як це питання вирішили наші колеги 3 усього світу. Українське дослідження Великодної та Циганенко (2020) показало, що під час перших локдаунів 83\% спеціалістів обрали віртуальні сесії, в той час як решта припинила працю. У Південній Африці, здається, більшість спеціалістів обрали 
роботу онлайн, хоча це непідтверджена інформація. 3 точки зору етики, швидкий перехід на роботу онлайн $\epsilon$ етичним, тому що це рішення приймається в інтересах пацієнта, незважаючи на відсутність часу на підготовку. Реальність зробила підготовку неможливою. Найважливішим питанням було продовження сесій.

В одній з глав нещодавно опублікованої книги під назвою Ковідне життя (Covidian Life, 2021) бельгійський психоаналітик Серж Фріш описує той початковий перехідний період ковіду та відповіді на цей виклик, що, мабуть, резонує для багатьох $з$ нас. Він пише: "У той час як поняття аналітичної рамки дуже дороге моєму серцю, я не дав собі або своїм пацієнтам жодного моменту для осмислення та аналізу цього нападу на рамки, хоча зазвичай я че роблю, коли пацієнт починає випробовувати рамки на сесії. ... Зараз я розумію, що мої аналітичні здібності повністю підвели мене. Я здатен прийняти, що це могло зі мною статися. Але як може бути, що вся професія відреагувала більш-менш однаково? I що я міг передати своїм пацієнтам відносно своєї тривоги та психічної некоректності, що призвели до такої поведінки - дій, що повністю суперечать моєму звичному підходу, згідно з яким я би взяв якийсь час на осмислення разом з пацієнтами, перш ніж реагувати на якийсь запит".

Як зазначає Фріш, спеціалісти діяли всупереч традиційним аналітичним стосункам та техніці. Наші пацієнти, вдячні за можливість продовжувати сесії, відчули цей швидкий перехід онлайн згідно зі своєю унікальною психодинамікою. Дуже важливо дізнатися значення, яке все це мало для кожного з нас. Але це буде можливо, тільки якщо ми насамперед пропрацюємо наш найглибший досвід.

Початковий шок, викликаний пандемією, змусив спеціалістів заклякнути від тривоги та послабив їхню здатність до стану генеративної невпевненості або підтримання звичайного 
ступеня рецептивності в контрперенесенні. Можливо, ми усвідомлюємо, що в той період наша робота була не такою як завжди. I це зрозуміло. Але чи може це нести небезпеку у вигляді більш довгострокової сліпоти в контрперенесенні? Це як антиутопічна версія американської фрази: “Що відбувається у Вегасі, залишається у Вегасі". Тобто може виникнути захисне відчуття - все, що сталося під час епідемії Covid-19, насправді не рахується, бо ми переживали щось безпрецедентне. Існує небезпека витіснення цих переживань, ігнорування дискомфорту з приводу неочікуваних речей, до яких ми були змушені адаптуватися, тому що вони настільки відрізнялися від наших звичних шляхів існування, що суперечили нашій базовій аналітичній ідентичності.

Саме ці побоювання змусили мене та мою колегу, тренінганалітика, створити групи для психоаналітиків Південноафриканської психоаналітичної асоціації (SAPA) та присвятити їх темі "Робота аналітиком у часи Covid-19". Групи створювали простір для контейнерування тривог, пов'язаних з пандемією, та нашого досвіду раптової потреби працювати онлайн. Озираючись назад, ці групи допомогли нам, організаторам, не менше, ніж іншим учасникам.

Зараз я наведу приклад із супервізії, щоб показати, як неопрацьоване контрперенесення терапевта, пов'язане з раптовістю Covid-19, вплинуло на неї. Пан Дж. - пацієнт із фантазіями, пов'язаними з його вірою в те, що його тіло вкрай бридке. У їх роботі віч-на-віч, він виражав потребу в тому, щоб бачити вираз обличчя терапевта, для того щоб мати змогу оцінювати, що вона насправді відчувала по відношенню до нього. Через глибоке почуття сорому та ненависті до себе, йому було важко встановлювати прямий зоровий контакт з нею, і замість цього відбувався дуже короткочасний периферійний зоровий контакт, який допомагав йому нічого не пропускати. Він коментував найменші зміни в їі поставі або поведінці. Це було 
негативне перенесення матері, яка відштовхує свою дитину, бо вважає її вкрай нестерпною, хоча й робить вигляд, що цього немає, в той час як це виражається ії рухами. У перший місяць онлайн роботи через Covid-19, пан Дж. відчайдушно намагався звикнути до віртуальних сесій, хоча як і завжди, він все ще не спізнювався ані на хвилину. Але його стрес виражався в менш послідовній манері говоріння. Він не закінчував речення та занурювався у важку та тривожну тишу. Терапевт помітила дискомфорт пацієнта, але не відчула потреби досліджувати його глибоко. Її захисні думки полягали в тому, що, оскільки перед ними був вибір працювати онлайн або залишитися без терапії, йому треба прийняти реальність і він скоро заспокоїться.

Зрештою, аналітик змогла побачити, що вона захищалася від глибокого почуття провини за перехід в онлайн, що призвело до розігрування сліпоти по відношенню до його стресу, повторення його дитячого досвіду.

Таким чином, вона могла пам'ятати про свої початкові почуття того, що з усіх пацієнтів пан Дж. відчував найбільший стрес через втрату сеттингу роботи в кімнаті.

Знаходячись під впливом психічного нападу пандемії, вона стала функціональною матір'ю, що виконувала практичні кроки піклування про пацієнта. Коли вона змогла зрозуміти, що сталося, її аналітичне ставлення відновилося достатньо для того, щоб вона могла інтерпретувати те, наскільки важко для пана Дж. було втратити знайому кімнату та тіло терапевта в цій кімнаті. На додаток до втрат, він напевно відчуває себе переповненим потребою в прямому зоровому контакті, адже це єдиний спосіб перевірити реакцію терапевта на себе. Терапевт ніколи б не працювала онлайн з цим пацієнтом, зважаючи на певні труднощі, але глухий кут, що виник, та його вирішення привели до поглиблення роботи, яка тепер знову проводиться віч-на-віч. 
I це приводить нас до теми, чи підходить пацієнт. До пандемії література останніх 15 років вивчала плюси та мінуси онлайн роботи. Було помічено, що зростаюча кількість спеціалістів тією чи іншою мірою використовували онлайн режим у клінічній практиці в особливих ситуаціях, наприклад, коли пацієнт працював за кордоном або хворів і був прикутий до ліжка. Але етичні настанови говорять про те, що ключовою $\epsilon$ оцінка пацієнта - він не має бути в групі підвищеного ризику, не може мати в анамнезі важких ранніх травм або суїцидальних спроб. Такі більш порушені пацієнти не могли розглядатися як кандидати на віртуальну роботу, якщо були можливості працювати наживо.

У цілому, статус клінічної роботи онлайн усе ще був суперечливий. 3 іншого боку, поширеними стали онлайн супервізії, які менше покладаються на міжособові взаємодії та надають доступ до справжнього пантеону аналітичних розумів. Важливо, що у 2017 році IPA прийняла рішення дозволити аналіз онлайн, навіть у випадках тренінг-аналізу, в разі наявності особливих обставин та певних обмежень. Це був справжній тектонічний поштовх, що походив з найбільш ортодоксального підходу до психоаналізу. Але навіть зважаючи на це, частиною етичних рамок усе ще залишилася повільна та обережна підготовка до онлайн роботи. Певні типи роботи вважалися неможливими онлайн, наприклад, ігрова терапія. Але все змінилося з приходом Covid-19, і я поділюся з вами цікавим досвідом.

Упродовж першого локдауну ми помітили, що пацієнтамдітям віртуальні сесії - телефоном або відеозв'язок - давалися важче. Це має сенс з точки зору розвитку. Ще одним викликом $\epsilon$ те, що пацієнт бере на себе рівну долю відповідальності за захист сеттингу та конфіденційності. Звісно, діти менш спроможні до цього, ніж дорослі, не кажучи вже про їхню невротичність. Але ми зрозуміли, що діти не були справжньою проблемою! Дитячі терапевти розповідали про такі порушення 
рамок, як батьки, що входять до кімнати, де відбувається сесія, та самі стають частиною сесії, розмовляючи з терапевтом та граючи зі своїми дітьми. Усе це відбувалося за умови чітких терапевтичних меж, встановлених до початку епідемії, і причини цих меж були пояснені на зустрічах з батьками.

Звісно, відсутність фізичного шляху до та з лікарні, а також відсутність моменту сепарації від батьків перед походом до терапевта також призвели до колапсу кордонів. Терапевтам довелося дуже важко працювати, щоб відновити терапевтичні кордони. 3 більш порушеними родинами це треба робити знову й знову. Цікаво те, що були й неочікувані здобутки в тому, що цей процес сприяв переходу розмов про кордони на глибший рівень - він був буквально винесений у будинки та родинні стосунки пацієнтів. Що стосується згаданої мною справи, стало очевидно, що важливість міжособових кордонів не була інтерналізована пацієнтом - він скоріше слідував правилам у своїй поведінці, в той час як кордони сприймалися як ексцентричне правило, яке працювало лише в будівлі Дитячої клініки.

У тих двох прикладах, якими я вже поділилася, були виклики, але й неочікувані здобутки, викликані опрацюванням впливу внаслідок раптового переходу в онлайн режим. Тема несподіваних здобутків порушувалася багатьма авторами, наприклад, Айбелем та Ферро, які зараз сумніваються в своїй минулій нерішучості щодо віртуальної роботи, зазначаючи, що вона може приносити певну унікальну терапевтичну користь. Це приводить нас до питання, чи є робота наживо все ще золотим стандартом і чи вона в інтересах пацієнта? Щоб мати змогу слідувати за своєю етичною полярною зіркою, нам потрібно дійсно подумати про відмінності. Наявна література містить різні погляди; автори, такі як Рассел і Фріш, поділяють думку, що робота онлайн, хоча й краща, ніж нічого, є слабкою заміною. Вони висловлюють занепокоєння про постковідний 
період стосовно того, що пандемія та невідкладні поправки могли викликати непомітне калібрування віртуальних сесій, до яких до цього відносилися з обережністю та умовностями.

3 іншого боку, автори, такі як Шарфф та де Стааль, пропонують нам залишатися відкритими до досвіду та спостережень за нашою роботою онлайн, щоб побачити, чого ми можемо навчитися, перш ніж доходити до швидких висновків. Деякі автори відчувають, що навіть глибока робота в перенесенні-контрперенесенні все ще можлива, наприклад Гордон та ін. і Лемма (2015). Але як ми зможемо це реально оцінити?

\section{Перенесення та контрперенесення}

Психоаналіз завжди був методом лікування тіла та розуму. Сама сутність психоаналітичного лікування - на перенесення дуже впливає відсутність тілесної присутності, адже перше Я це завжди тілесне Я. Важлива робота Бейліс 2012 року задає таке питання: чи $є$ фізична близькість необхідною для психоаналітичного процесу? Вона говорить про те, що шляхом теоретичного прогресу психоаналіз змістив фокус з лише вербального обміну на сесіях на більше визнання важливості невербальної комунікації. Вона описує інтеркативний процес між двома тілами як сенсорну реєстрацію, імпліцитну та процедурну, між двома людьми. Саме це, стверджує авторка, порушується в умовах роботи онлайн. Цілий вимір роботи втрачається або напевно приглушується. У нещодавній роботі Фернадес-Альварез та Фернандез-Альварез дійшли висновку, що, хоча віртуальні сесії можуть зробити терапію більш доступною, терапевтичному альянсу та процесу заважає відсутність паралінгвістичних, невербальних та просодичних аспектів міжособової комунікації. В умовах віртуальних стосунків, відповідальність за словесне вираження тілесно-афективних станів лягає на пацієнта, бо аналітик не може реєструвати їх звичайним шляхом.

Тобто, в кращому випадку, пацієнти повинні нести додатковий тягар, відсутній в умовах очної роботи. У найгіршому 
випадку, невербальний шар вираження губиться пацієнтами, які намагаються зрозуміти та символічно передати свої внутрішні стани. Усе це підтримує ідею про необхідність старанної оцінки, коли постає вибір між очною роботою та онлайном.

Первинна ідея психоаналізу полягає в методі, що працює 3 конфліктами стимулів, які виникають у кімнаті. Очне лікування уможливлює розігрування люблячих та агресивних бажань по відношенню до терапевта. Правило стриманості таким чином $\epsilon$ потужним імпульсом для перенесення, коли стимули виражаються непрямим чином. Звісно, імпульсні бажання присутні й у віртуальному вимірі, але вони не виражаються прямо. Напевно, це має значний вплив на терапевтичний процес? Зараз ми говоримо про ефект втрати фізичної присутності у віртуальних стосунках. Це питання обговорювала Ісаакс Рассел, яка зробила важливий внесок у сферу психоаналізу з використанням технологічних посередників. Вона пояснює, що $з$ нейропсихологічної точки зору, відчуття присутності $€$ можливим завдяки відчуттю фізичної локації у світі та нашому відчутті того, як ми можемо впливати на світ своїми діями. Авторка каже, що присутність відрізняється від емоційного контакту або сфокусованої уваги. В усіх прикладах, які я наводжу, ситуації виникли в результаті втрати присутності та взаємної присутності. Наступний приклад виводить це питання на передній план.

Я працювала зі Стівеном, чоловіком за 50, в аналізі чотири рази на тиждень. На другий рік аналізу він розвинув сильне захисне еротичне перенесення, феномен, що описується Фройдом в його роботі “Спостереження за перенесенням любові”.

Стівен ділився своїми наочними сексуальними фантазіями про те, як він хотів займатися сексом з аналітиком, і цей процес включав в себе меблі, які були розташовані в кімнаті. Отже, захисна сексуалізація була не тільки по відношенню до терапевтичних відносин, але й до всієї кімнати в цілому. Частина потужного впливу в контрперенесенні була пов'язана з тим, що 
аналітична пара була в кімнаті разом. Контрперенесення було сумішшю збудження та тривоги, що відчувалася небезпечною. Я повинна була справлятися з цими сильними нападами на мій розум; саме амальгама сексу та агресії повинна була інтерпретуватися, що я й робила знову і знову впродовж нашої роботи. На жаль, Стівену довелося припинити лікування за декілька місяців до початку пандемії через деякі життєві зміни. Мені цікаво, як би змінився цей аналіз, якщо б він не закінчився тоді, і нам довелося б працювати віртуально. Як би відрізнялися перенесення та контрперенесення? Якби пацієнт ділився своїми фантазіями онлайн, не маючи спільної фізичної присутності, тон був би зовсім інакшим. Живість та реальна можливість актуалізації імпульсних бажань були би відсутніми на сесіях. Звісно, пацієнт знайшов би інший шлях, але це змінило би форму матеріалу та в свою чергу й увесь процес.

Я обговорювала цей процес з колегою, яка повідомила, що в своїй роботі їй вдалося помітити різницю у вираженні еротичного перенесення, особливо з одним пацієнтом. Вона побачила, що його опір - який попередньо виражався в непримиримій вимозі стати коханцями - зник на віртуальних сесіях. Ранні відносини пацієнта з матір'ю були дуже складними та містили інцестуозні аспекти. Аналітик помітила, що з повним зникненням можливості статевого акту на віртуальних сесіях, пацієнт приніс винуваті, тривожні та депресивні почуття, від яких він раніше захищався шляхом еротизації відносин.

Ми без сумніву дізнаємося набагато більше про психоаналітичний процес, коли ще більше колег зможуть розповісти про свій досвід. У майбутньому питання про вплив на терапевтичний процес потребуватиме обережного осмислення, тому що це питання етичне.

\section{Більш ніж один тип Рамки}

Але, тим часом, нам необхідно подумати про те, як найкраще впоратися з наявною ситуацією. Як ми утримуємо рамки 
та слідуємо правилам у поточний період, коли ми все ще живемо в умовах пандемії? Наразі використовуються декілька шляхів встановлення рамок. Перший $є$ психоаналітичним прототипом, який ми можемо називати стабільною рамкою. Другий тип нещодавно обговорювався Фрішем, який використовує термін плаваюча рамка для опису ситуації, в якій терапевт допускає гнучкість сеттингу не тільки в ситуаціях ризику для здоров'я, але й задля зручності кожної зі сторін. Фріш має дуже вагомий аргумент проти такої практики. Отже, плаваюча рамка кардинально відрізняється від стабільної. Але стабільна рамка може існувати, коли сеттинг поєднує як живі, так і онлайн зустрічі, поки є наявним чіткий стабільний план. Така рамка існувала й до Covid-19. Наприклад, аналітичні кандидати в деяких перевантажених великих містах мають певну кількість онлайн сесій на тиждень. Якщо б така домовленість не була дозволена, 4-5 сесій на тиждень були б неможливими. Для зручності обговорення таку домовленість можна називати модифікованою стабільною рамкою.

Але це не вирішує проблеми сьогодення.

Я пропоную прийняти чутливу (responsive) стабільну рамку як тимчасову адаптацію до реальності, в якій існує вірогідність подальших локдаунів, хвороб або заражень. Чутлива стабільна рамка встановлюється шляхом обговорення з пацієнтами, і таким чином встановлюються нові правила сеттингу. Це також можна вписати в контракт. У будь-якому разі, будуть зафіксовані чіткі умови лікування, особливо в ситуаціях, коли плануються як очні сесії, так і сесії онлайн. Наприклад, можна сказати, що всі сесії будуть очними, тільки якщо не буде локдауну або контакту будь-якої сторони з хворою людиною тощо. Сюди також можна включити домовленості щодо віртуальної роботи, в разі якщо пацієнт, наприклад, подорожує в справах. Формальна домовленість може здаватися непотрібною, нібито все це само собою зрозуміло. Але вважати 
так було б помилкою. Якщо ці моменти належно не обговорити та не прийняти, ми з вами провалимо завдання рішучого підтримання рамки.

Я наведу приклад переваг, які дає чутлива стабільна рамка. Коли пацієнт забуває про очну сесію та все ще хоче сесію, але вже онлайн, тільки чітко встановлені правила сеттингу допоможуть нам зрозуміти, що це - його виклик рамкам, змінна, яку треба аналізувати та опрацьовувати. Якщо ми не формалізуємо нові домовленості про рамки, ми можемо відчути скомпрометованою нашу здатність підтримувати свою аналітичну роль. У дестабілізованому стані сум'яття може призвести до втрати стриманості та до бажання уникнути конфлікту. Ми можемо погодитися і таким чином увійти в змову.

Роблячи це, ми втратимо можливість дослідити амбівалентність, опір та захисну фантазію пацієнта. Іншими словами, буде скомпрометована глибина роботи. Втрата стабільності може також залишити пацієнта з відчуттям того, що аналітик став перманентно послабленим об'єктом, який більше не може утримувати його в аналітичному процесі.

$\epsilon$ також i інші етичні моменти, які можуть виникнути в умовах такого побічного ефекту Covid-19 як послаблення етичності. Ми ризикуємо приймати рішення, які не будуть в інтересах пацієнта і які базуються на таких причинах, як уникнення закінчення, або ще гірше, на наших власних фінансових інтересах.

\section{Висновок}

Розглянемо останній приклад як висновок доповіді. У попередній роботі 2017 року я писала про випадок пані Б., з якою я працювала в психотерапії два рази на тиждень. Після 6 місяців терапії робота пані Б. вимагала від неї переїзду в інше місто. Вона спитала, чи можемо ми продовжити роботу онлайн. I хоча мені подобалося працювати з нею, я прийняла рішення не працювати онлайн з декількох причин. У місті, куди переїжджала 
пані Б., є дуже розвинена психоаналітична спільнота, а пані Б., хоч і функціонувала добре, іноді виражала свої проблеми через порушення в харчуванні. Я вважаю, що такі психосоматичні труднощі потребують очної роботи. Крім того, лікування все ще було на дуже ранній стадії, і моє відчуття було таким, що тут була потрібна саме очна робота для вираження та опрацювання перенесення. I нарешті, збереження цієї терапії не здавалося настільки ж важливим для розвитку пацієнтки, як довгострокове очне лікування.

I хоча нам обом було сумно через те, що ми не могли продовжувати працювати разом, припинення терапії мало значення для подальшого розвитку. Важливо було не увійти в змову задля уникнення болю сепарації та втрати, а дати простір для важливої роботи над скорботою.

Ця ситуація сталася за декілька років до Covid-19, в часи, коли я погодилася на роботу онлайн тільки з одним пацієнтом, який декілька тижнів на рік подорожував у робочих справах. Коли я писала статтю у 2017 році, я й уявити не могла часи, коли я декілька місяців буду працювати з усіма своїми пацієнтами онлайн. Я також не очікувала, що зможу виконувати таку роботу, яка власне виявилася можливою. Коли я писала цю роботу, я запитала себе: якби я мала таку ситуацію зараз, чи я $б$ так впевнено відмовилася працювати з пані Б.? Відповідь усе ще “так”, хоча це "так" уже менш рішуче.

Хоча психоаналіз пройшов багато важливих етапів розвитку та змін за останні більш ніж сто років, постійність сеттингу та важливість очної роботи є основами цієї дисципліни, якими не можна зневажати задля зручності. Розум - це тілесний розум. Цей факт ніколи не зміниться, саме тому глибока психоаналітична робота потребує стабільних рамок та тілесної присутності в аналітичному процесі, якщо це можливо. Ми маємо використовувати це розуміння як оплот в умовах неминучих майбутніх викликів, щоб рухатись далі й залишатись гнучкими. 


\section{Література:}

1. Aibel, M. (2020). The joy of the session (notes from the pandemic quarantine). Attachment: New Directions in Relational Psychoanalysis and Psychotherapy, 14(2), 193-203.

2. Bayles, M. (2012). Is physical proximity essential to the psychoanalytic process? An exploration through the lens of Skype. Psychoanalytic Dialogues, 22(5), 569-585. doi: https://doi.org/10.1080/10481885.2012.717043

3. Bleger, J. (1967). Psycho-analysis of the psycho-analytic frame. International Journal of Psycho-Analysis, 48, 511-519.

4. Fernández-Álvarez, J., \& Fernández-Álvarez, H. (2021). Videoconferencing Psychotherapy During the Pandemic: Exceptional Times With Enduring Effects?. Frontiers in Psychology, 12. doi: https://doi.org/10.3389/fpsyg.2021.589536

5. Ferro, A. (2021). Like a fish in water. Psychoanalytic Psychology, 38(2), 140. doi: https://doi.org/10.1037/pap0000351

6. Freud, A. (1936). The Ego and the Mechanisms of Defense. New York: International Universities Press.

7. Freud, S. (1915). Observations on transference-love (further recommendations on the technique of psycho-analysis III).

8. Freud, S. (2001). The Complete Psychological Works of Sigmund Freud Vol. 12: The Case of Schreber, Papers on Technique and Other Works (Vol. 12). Random House.

9. Frisch, S. (2021). Individual distress, institutional distress. Psychoanalysis and Covidian Life: Common Distress, Individual Experience. Phoenix.

10. Giustino, G. (2021, August). Psychoanalysis online: An interview with Jill Savege Scharff. International Forum of Psychoanalysis (pp. 1-2). doi: https: / /doi.org/10.1080/0803706X.2021.1939148

11. Gordon, R. M., Wang, X., \& Tune, J. (2015). Comparing psychodynamic teaching, supervision, and psychotherapy over videoconferencing technology with Chinese students. Psychodynamic psychiatry, 43(4), 585-599. doi: https://doi.org/10.1521/pdps.2015.43.4.585

12. Isaacs Russell, G. (2021). Remote Working during the Pandemic: A Second Q\&A with Gillian Isaacs Russell. British Journal of Psychotherapy, 37(3), 362-379. doi: https://doi.org/10.1111/bjp.12654

13. Ivey, G. (1999). Thoughts on the 'analytic attitude'. Psycho-analytic Psychotherapy in South Africa, 7(1), 1-18.

14. Kadish, Y. (2017). From Knowing to Discovering: Some suggestions for work with an anorexic patient. In Psychoanalytic Treatment of Eating Disorders (pp. 99-112). Routledge. 
15. Klein, M. (1946). Notes on some schizoid mechanisms. International Journal of Psycho-Analysis, 27, 99-110.

16. Langs, R. J. (1989). The Technique of Psychoanalytic Psychotherapy: Theoretical Framework: Understanding the Patient's Communications (Vol. 1). Jason Aronson, Incorporated.

17. Lemma, A. (2015). Introduction to the practice of psychoanalytic psychotherapy. John Wiley \& Sons.

18. Milner, M. (1952), Aspects of symbolism in comprehension of the not-self. International Journal of Psycho-Analysis, 33:181-195.

19. Schafer, R. (2019). The analytic attitude. Routledge.

20. de Staal, A. (2021). The burnt compartment. Or: Psychoanalysis without a couch. Psychoanalysis and Covidian Life: Common Distress, Individual Experience, 107.

21. Velykodna, M., \& Tsyhanenko, H. (2021). Psychoanalysis and psychoanalytic psychotherapy in Ukraine during the COVID-19 pandemic unfolding: the results of practitioners' survey. Psychological journal, 7(1), 20-33. doi: https://doi.org/10.31108/1.2021.7.2 
УдК 159.964

DOI

\section{Галина Савченко}

Сертифицированный психоаналитик, тренинговый аналитик и супервизор ЕКПП, председатель Одесского психоаналитического общества,

член и глава этической экспертной группы

Дивизиона “Психоаналитическая психология и психотерапия"

Национальной психологической ассоциации Украины

https://orcid.org/0000-0002-8497-6822

\section{НОВАЯ ЭТИКА. ЛЮБОВЬ, СЕКС И ОТНОШЕНИЯ В ЧЕТВЕРТОМ ИЗМЕРЕНИИ}

Уважаемые коллеги. В своем сегодняшнем выступлении я хочу предложить вам поразмышлять о том, как революционно изменился мир, человек и его отношения со времен открытия и описания психоаналитической теории Зигмундом Фрейдом.

Цифровизация всех сфер человеческой жизни, которую ускорили локдаун и пандемия, вынудила нас приспосабливаться к новому, четвертому измерению, активно переносить туда все свои связи, работу, отношения, а также обучаться особенностям, алгоритмам и, по роду нашей помогающей профессии, быть проводниками в новом неизведанном мире.

В профессиональном дискуссионном поле появляется много полемики в плоскости хорошо это или плохо - коммуникации онлайн, и нужно ли психоаналитику осваивать цифровое измерение так же, как когда-то переселенцы осваивали Америку?

Пандемия сломала и изменила алгоритм привычного мира, как библейский «всемирный потоп», обнулила его и заставила нас принять новое как неизбежность. 
Говорить о том, хорошо это или плохо - не имеет смысла. Новое принимают и живут в нем, или не принимают и сходят с корабля реальности в лету истории.

И на мой взгляд, нам нужно осознавать и анализировать революционные пространственно-временные изменения не в старом дискурсе привычного физического мира, а в контексте принятия нового, его возможностей и ограничений. Необходимо наблюдать, как изменяется сам человек, его личные и социальные связи, а также то, как в этой связи должен измениться психоанализ, который исполняя основное правило следует за человеком/пациентом и помогает ему в преодолении сложностей его жизненного пути.

Мы участники и творцы новейшей психоаналитической истории, мы очевидцы и в каком-то смысле пионеры в цифровом психоаналитическом мире. Экспериментаторы и проводники. И мне кажется, что в настоящем времени никто лучше психоанализа не может понять динамику изменений, описать ее и предложить интерпретации происходящих в человеческой жизни изменений.

Я полагаю, что мы в самом начале длинного профессионального дискуссионного пути.

Современный мир - это мир электроники, скоростей, цифровой связи и искусственного интеллекта.

Современный мир - это строительство исследовательского центра на Марсе, редактирование генома человека и, конечно цифровое измерение - новый космос, существующий рядом с человеком 24/7, на расстоянии «вытянутой руки».

Виртуальное пространств - это мир грез, в котором многие из нас успешно работают, дружат, общаются и заводят любовные отношения.

Это волшебный мир зазеркалья, который существует специально для нас и для исполнения наших желаний! Надо только как в детской сказке, сказать заветные крибле-крабле 
бумц, набрать в строке браузера правильные знаки, и волшебный мир к вашим услугам!

Одновременно это и потерянный рай, в котором мы пребывали, еще не родившись, в животе у наших матерей.

Он удивительно похож на мир сновидений или особых сомнамбулических состояний, в которые мы погружаемся в определенные моменты времени. Только теперь это сон наяву!

Сегодня и всегда этот мир грёз рядом с вами, за экраном гаджета.

Это ваш личный цифровой космос, в который вы можете выходить из любой точки реального мира, как в кабинет, стоит вам только надеть наушники!

И вы можете оставаться там так долго, как пожелаете, попрежнему продолжая жить в реальности, и даже время от времени коммуницировать с окружающими вас людьми, не выходя из цифрового формата!

Эти две вселенные существуют параллельно и не пересекаются, и только человек служит звеном, которое их объединяет....

Что происходит с этим человеком, живущим одномоментно в двух мирах?

Возможно, он приобретает свойства бога, управляющего вселенной?

Королевская дорога в бессознательное

С самого начала открытия бессознательного и зарождения психоанализа, Фрейда заинтересовали сновидения.

И мы знаем, что в 1895 году 24 июля в одном венском ресторане, размышляя на фундаментальные психоаналитические темы, он сформулировал идею о том, что сновидение представляет собой набор кодов и шифров бессознательного, в котором находят свое удовлетворение вытесненные желания сновидца. 
Именно в это время он сформулировал свой ключевой тезис о том, что сновидение - это королевская дорога в бессознательное.

Но уже к 1938 году (через почти 40 лет) в своей работе по технике лечения он пишет, что

«Сновидение - это психоз, со всеми его нелепостями, бредовыми образованиями, обманами чувств такового. Правда психоз кратковременный, безвредный и даже наделенный полезной функцией. Начинающийся с согласия человека и оканчивающийся изъявлением его же воли...»

И если мы размышляем на тему цифрового мира, который сегодня осваивает современное человечество, то понимаем, что он во многом устроен по принципу сновидения и значит тесно связан с психоаналитическим пониманием психоза.

И поэтому мы можем перефразировать, что сны наяву это королевская дорога в психотический мир, со всеми вытекающими (тяжёлыми или легкими) последствиями. Цифровая коммуникация накладывает свой отпечаток на любую личность человека и изменяет ее.

Мы наблюдаем странности в поведении людей, которые в силу своей профессии большую часть времени проводят в интернете, и не просто в социальных сетях или мессенджерах, а по - настоящему беседуют с цифровым разумом на его языке.

Как пребывание в цифровой психотической среде меняет человека?

Людям становиться все труднее поддерживать душевную связь, они не готовы эмоционально тратиться на заботу о комто кроме себя. Биологически оставаясь людьми, они теряют важные человеческие качества - интерес к другому, совместное творчество и доверие к будущему

Мы знаем, что психоанализ начинался с лечения истерии, и был разработан для лечения неврозов, но в середине прошлого столетия психоаналитический мир заговорил о нарциссическом пациенте на психоаналитической кушетке, и теория 
Лакана, его дискурс о наслаждении, желании большого Другого, об изоляции субъекта и пр. стали своевременным ответом на бессознательный запрос социума и нового нарциссического мира, обслуживающего потребности грандиозного Я нарциссического субъекта.

С каким психоаналитическим пациентом имеет дело современный психоанализ, и можем ли мы сформировать гипотезу о будущем социальном субъекте наблюдая революционные изменения окружающего мира, уже сейчас?

«В моей недавно вышедшей в свет работе «Я и Оно», - говорит Фрейд, сравнивая неврозы и психозы, - я указал на расчленение душевного аппарата, на основе которого можно в простой и наглядной форме изложить целый ряд отношений...

...Я самовольно создает себе новый внешний и внутренний мир, и нет никаких сомнений в двух фактах: в том, что этот новый мир построен в духе импульсов-желаний ОНО и что мотив этого разрыва с внешним миром - тяжелая, кажущаяся невыносимой фрустрация желаний, относящихся к реальности. Нельзя не заметить внутреннего родства этого психоза с обычным сновидением...»

Таким образом можно с уверенность сказать, что сетевой мир погружает человека в контент бессознательного, в пространство психопатической вселенной, где понятие нормы и патологии меняются местами....

Либидинозный драйв, катектируется на Я, и мы имеем дело с субъектом, инвестирующим самое себя. Агрессивный же драйв выводится вовне и становиться архаическим преследователем, от которого субъект защищается, убегая в мир грез, в безопасное пространство четвертого измерения, обретая силу и бессмертие. Таким образом любовь, сексуальность и отношения приобретают другой смысл и контекст.

И становиться понятно почему последняя сексуальная революция второй половины двадцатого века прошла под знаком 
изменения отношения к сексуальным перверсиям. Все, что сейчас происходит в сексуальной и личной жизни человека ее последствия, помноженные на тотальную диджитализацию общества, в результате угроз пандемии.

Эта толерантность строится на более демократичных и свободных взглядах на женскую телесность и сексуальность, а также на попытках принятия взрослой мужской и женской гомосексуальности. И наверно это естественно, если мы имеем дело с невротическим субъектом.

А если нет? Если давно уже не существует никакого невротического субъекта? И объект психоаналитического исследования - психотик или социопат?

\section{Психоз, травма и сексуализация общества} как новая норма социальной связи

М.Фуко в своей концепции сексуальной революции говорит о «Сексуальной репрессии», которая - согласно 3. Фрейду относится к феномену массообразования. Это действие направлено на подавление свободы и запускается через сексуальную революцию, несущую сексуальную и социальную свободу.

Известный британский социолог, изучающий новую общественную мораль и сексуальность - Энтони Гидденс описывает современную сексуальности, вводя новое понятие - «пластичной сексуальность»

«Пластичная сексуальность - это децентрализованная сексуальность, освобожденная от репродуктивных потребностей.»

Новая сексуальность в современном мире больше не задана биологией, это вопрос личного выбора. И с одной стороны это новая публичная нормальность, а с другой - глубоко личное дело.

Но вернемся к Фуко и его анализу современных социальных феноменов. 
«В обществе постмодерна, - говорит он, - секс становиться точкой фиксации». Современным способом исповедоваться, на манер церковной исповедальни.

Согласно Фуко, сексуальность выступает как ключевая связка между идентичностью, телом, и социальными нормами.

Эротическое наслаждение превращается в "сексуальность" по мере того, как в профессиональной литературе появляются тексты, в которых она изучается как "феномен", и главное, где определяется понятие "нормы" и "отклонения".

Соответствующий дискурс создается на базе "научного объяснения" нормы и патологии. Поэтому сексуальность приобретает признаки социального продукта, инициированного властью.

Что изменяется в обществе с открытием четвертого, цифрового измерения? Как живет, любит и строит отношения человек в пространстве, организованном по принципу функционирования бессознательного? В психотической вселенной, без ясных границ и властных структур, где сам индивид и есть власть?

И где тогда, согласно психоаналитическому механизму смещения, мы должны ожидать появление пространства для сексуального отыгрывания и «исповедывания»!?

В современном обществе мы наблюдаем тенденцию к затрудненной способности выражать чувства словами наряду с неумением справляться с собственными эмоциями.

По-простому - налицо неспособность большинства современных людей сконструировать изложение себя, и репрезетновать его в объектных отношениях реального телесного мира.

Но виртуальное пространство более пластично и поддается манипулятивным преобразованиям дезинсвестирующим личное Я.

В результате инфляции Я происходит структурный поворот и "Тень объекта падает на Я» или «объект берет верх над Я» или «рассматривает само себя как объект» - так в известной работе «Скорбь и меланхолия» Фрейд описывает психотические реакции субъекта, связанные с потерей объекта. 
Возможно что-то похожее происходит и в виртуальной реальности, являющейся нарциссическим расширением субъекта, в которой он получает иную, цифровую идентификацию и цифровую репрезентацию себя, превращаясь таким образом, в пакет информации и расчеловечиваясь. .....

«Секс в современной цивилизации не загоняется в подполье», но перерастание его в продукт, особенно в контексте тотальной цифровизации, расширяет понимание термина ПРОСТИТУЦИЯ и ПОРНОГРАФИЯ и вПлОтнУю Подводит нас к обновленному пониманию термина ДЕВИАЦИЯ. Сексуальность и телесность, приобретая признаки продукта, начинают существовать сами по себе, отдельно от человека, как субъекта реального мира.

И несмотря на свободную сексуальную мораль, сексуальных отношений в мире становиться все меньше и меньше, и они заменяются сексуальными контактами

Цифровой мир погружает человека в контент бессознательного, в пространство психопатической вселенной, где понятие нормы и патологии меняются местами...

В четвёртом цифровом измерении человек может легко изменить свое тело, пол, возраст, способы построения отношений, он вообще может существовать там в совершенно другом, не человеческом образе и контексте.

Через связующее звено - человека, зазеркалье начинает влиять на нашу реальную жизнь, атакуя биологические, человеческие, системообразующие концепции реального мира и разрушая само понятие Человек.

И эту тотальную диджитализацию можно с полным правом рассматривать как травму, как тоталитарную угрозу, ставящую под вопрос существование человека, как биологического вида Хомо Сапиенс..

Я предлагаю осмысливать эти процессы через психоаналитическое понятие травмы, в которой отсутствует символизация 
и этот несимволизируемый опыт постепенно интегрируется в структуру архаического суперэго - инстанцию запрета и наказания, порождая пресекуторную тревогу и страх преследования.

И, вероятно, такое современное понимание травмы, может служить конструктом для тестирования реальности и понимания апокалиптических настроений ненадежности, и непредсказуемости мира на всех уровнях коммуникаций, начиная от родительско -детских, социальных и сексуальных.

Мертвая цифровая среда, как холодная мертвая мать формирует психотического субъекта, который строит отношения посредством проективной идентификации.

- Именно поэтому окружающий мир так разобщен (несмотря на все попытки соединить людей через дискурс мульткультурности и толерантности).

- Именно поэтому в современном мире активируется сексуальная перверсия как норма: тело становиться пустым сосудом, а сексуальное либидо инвестируется в цифровые клоны, парциальные объекты - сексуальные игрушки, или резиновых «Зин», которые по сути являются сексуальными фетишами, симулякрами и симптомами глобального психоза.

О влиянии анаклитической травмы на формирование психотического субъекта и его отношения с большим Другим, достаточно подробно писали Рене Шпиц и Джон Боулби.

И я соглашусь с идеей о современном психотическом обществе, о которой говорят многие современные психоаналитики.

В этом обществе в качестве нормы существуют феномены, свидетельствующие об игнорировании желания другого, - о его исключении. Эти новые, социальные формы коллективного расщепления, изоляции субъекта возникают как новая нормальность. А разрыв дискурса, как новый способ связанности и связи, построенный по аутическому принципу.

«Так или иначе, - пишет в интернет-альманахе известный философ Григорий Тульчинский, - но в настоящее же время, 
в силу ряда общецивилизационных факторов, активно формируется новая персоналия, в которой личность во все большей степени предстает как проект, или даже - как серия проектов. Разумеется, при этом не происходит отказа от статусных и ролевых идентификаций. Но они уже не тот гвоздь, на который вешается шляпа личности....»

Современный человек соблазнен цифровым космосом, который дает ему право Творца, всемогущество бога и иллюзию бессмертия.

Человек вытеснил из сознание свою смертность, и для успешного возвращения к себе ему нужно обрести чувство предела и границу бытия.

Говоря о новой норме, нельзя не вспомнить нашего современника, американского детского психолога Джея Белски (Belsky, 1999) который пишет о том, что мы должны пересмотреть вопрос о норме в отношениях. Амбивалентность и недоверие являются более нормальной формой отношений в современном мире.

Д. Белски доказывает, что в некоторых условиях избегающий или амбивалентный паттерны могут быть более адаптивными. Избегающие взрослые завязывают поверхностные отношения и предпочитают относительно бурную сексуальную жизнь. Скорее всего они не вкладывают душу в воспитание ребенка.

Подобная же связь, проистекающая из опыта лишения или травмы, подталкивает родителей воспитывать беспомощных и зависимых детей, которые став взрослыми, никогда их не покинут.

Размышление об этом побуждают нас пересматривать современное понимание психоаналитической рамки и психоаналитической практики.

Новая этика профессиональных отношений или современный пациент на психоаналитической кушетке. 
На мой взгляд, сейчас уже совершенно очевидно, что психоанализ и психоаналитическая практика должны обновиться. 3.Фрейд неоднократно подчеркивал, что как только будут лучше поняты эволюционные, структурные и динамические детерминанты более тяжелой, чем невроз, патологии, должны быть разработаны соответствующие техники для правильного психоаналитического подхода к ней.

За последнее время наше понимание клиники сложных, доэдипальных пациентов, существенно расширилась. И это открывает новые перспективы для понимания «нового пациента» на психоаналитической кушетке и инициирует размышление об обновлении психоаналитической техники и протоколов.

«Представляется, - пишет Хайнц Спотниц в своем исследовании на тему шизофрении, - что эти результаты ...достаточны для оправдания попыток, о которых говорил Фрейд, интеграции текущего психоаналитического знания, нормального и патологического развития, и текущей клинической экспертизы, в объединенную теорию, которая даст возможность развития психоаналитической техники, применимой в принципе ко всем уровням современного психоаналитического пациента»

Сегодня мы работаем в пространстве глобальной психической травмы, связанной не только с изоляцией и пандемией, но в большей степени с травмой от революционных изменений среды человеческого обитания, в котором внезапно возник и стал новой нормой - цифровой способ жизни, который и есть сама травма!

Цифровой психоз, отсутствие навыков символизации, диффузная идентичность и потеря телесности и сексуальности, привели новых пациентов с новыми проблемами в психоаналитические кабинеты.

Возникает вопрос - должны ли мы отказываться от работы с такими непонятными клиентами в связи с тем, что у психо- 
анализа нет терапевтических протоколов и сама психоаналитическая теория рекомендует не брать в психоанализ таких пациентов?

Мне представляется, что размышления об изменении технических приемов и сеттинга (в связи с новыми, в том числе и цифровыми психоаналитическими практиками) должны исходит из следующих замечаний (что изменяется?):

- Традиционная психоаналитическая рамка. Большая часть психоаналитических процедур в классической технике становится бесполезной или даже опасной в терапии пациентов страдающими более серьезными НЕ невротическими нарушениями.

- Традиционная диспозиция пациент-психоаналитик. Слабость психических структур современного доэдипального пациента, сильно затрудняет или делает невозможным, или ставит под вопрос использование кушетки и визуальную недоступность психоаналитика.

- Границы и безопасность. Неспособность или слабое разграничение себя и объекта, а также сложности в интеграции индивидуальных репрезентаций объекта и собственного Я, затрудняют развитие терапевтического альянса. Для многих пациентов психоаналитические сессии онлайн будут, возможно, одним из безопасных способов получать помощь.

- Трансфер и нейтральность. Особенности развития трансфера и трансферентных реакций у современного доэдипального пациента, говорят о большей включенности психоаналитика в процесс терапии, чем это было в классической технике. Психоаналитик более не «чистый экран» для проекций пациента, а контейнер для инвестиций. Психоаналитик сегодня нейтрален не к пациенту, а к конфликту внутри пациента.

- Контртрансфер. В современном цифровом мире, который более напоминает царство Танатоса, потребность в человеческих отношениях возрастает. Возрастает и роль контртрансфера, 
и чувств психоаналитика, которые необходимы современному пациенту, все более и более живущему в виртуальной реальности.

- Конфиденциальность. Психоаналитический процесс в цифровую эпоху расширяет понятие конфиденциальности психоаналитического действия. Тотальная открытость и безграничность сетевого мира, при определенной ловкости позволяет получить информацию о любом человеке, у которого есть хотя бы мобильный телефон. Принцип конфиденциальности в современном психоанализе остается неизменным, но значительно расширяется его толкование в психоаналитическом процессе.

Закончить эту интереснейшую тему о новой этике в четвертом измерении я хочу известным мифом о Гефесте, его супруге Афродите и ее возлюбленном Аресте.

Всегда занятый любимым трудом, Гефест мало бывал дома, и Афродита в его отсутствие предавалась любви с Аресом. Узнав об этом от всевидящего Гелиоса, Гефест решил наказать любовников. Он смастерил волшебную невидимую сеть и подвесил ее над ложем. Как только Афродита и Арес возлегли, сеть накрыла их, и они больше не смогла заниматься любовью.

Говорят, это были сети морали.

Из мифа мы узнаем о возникновении морали и нравственности - социальных сдерживающих инструментах, которые создают основание общества и помогают человеку контролировать свои инстинкты, а также структурируют Эго и формирует невротическую личность.

По иронии судьбы, в сегодняшнем расчеловечивании человека сети тоже играют важную роль.

Они соблазняют нас нарциссическим всемогуществом и сулят статус бога. Но не нужно заблуждаться, это не истерическое соблазнение, где тело и его театры играют первую скрипку. Цифровая сеть усиливает расщепление субъекта и отделяет тело от Я. 
Тело становиться обузой, мешающей человеку растворяться в сети.

Границы личности приобретает диффузную идентичность, соответственно архаический страх преследования и наказания усиливается. И я не погрешу против истины, если скажу, что эти тенденции отчетливо прослеживались уже на протяжении многих лет, предшествовавших пандемии.

И тогда сама пандемия, в этом контексте, воспринимается как симптом вяло текущего психоза, который материализует архаику бессознательного через манифестацию паранойи и ожидания наказания.

Все эти процессы только усиливают и проявляют модель новой реальности, которая входит в нашу жизнь все настойчивее!

Основные концепты, из которых будет произрастать и на которых будет базироваться новая этика и наша психоаналитическая работа, на мой взгляд таковы:

- во-первых, новая тоталитарность и новое принуждение,

- во-вторых, разрыв социальных связей.

- в-третьих - потеря телесности и расчеловечивание.

\section{Литература:}

1. Фрейд 3. Сочинение по технике лечения. Очерки психоанализа. Психоаналитическая техника (1938) «Фирма СТД». М. 2008. с. 409.

2. Фрейд 3. Психология бессознательного. Невроз и психоз. III т. «Фирма СТД». М. 2006. с 353.

3. Головин Ю.С. Словарь практического психолога. М 1998.

4. Гидденс Э. Трансформация интимности. Сексуальность, любовь и эротизм в современных обществах. СПБ, Питер 2004. С. 28.

5. Тульчинский Г. Л. Личность как успешный автопроект. Интернетальманах.

6. Спотниц Х. Современный психоанализ шизофренического пациента. ВЕИП СПБ. 2007. с. 44.

7. Belsky, J. (1999). Modern evolutionary theory and patterns of attachment. 
DOI

\section{Олег Христенко}

Психолог психоаналитической ориентации, практик и исследователь психоанализа, преподаватель Международного Института глубинной психологии, член Дивизиона “Психоаналитическая психология и психотерапия" Национальной психологической ассоциации Украины https://orcid.org/0000-0001-8991-0227

\section{ПСИХОАНАЛИЗ ОЧНО И ОНЛАЙН: ЭТИКА, ДИСКУРС, КАДР}

\section{Психоанализ между формой и этической строгостью}

Картина психоаналитического кадра, как многолетней работы на кушетке, четыре или три раза в неделю по 45-50 минут - устоялась достаточно прочно, хотя таким психоанализ был недолго. Он таким не был ни у Фрейда, ни у Ференци, таким он перестал быть и после Лакана. Конечно же, есть психотерапевтические объяснения ритма, частоты и продолжительности психоаналитической работы, мы это видим в клинической работе Винникотта, Грина и других психоаналитиков, но это еще не составляет суть психоанализа и даже не является формой, а является техническим средством.

Но для начала давайте вспомним, чем же является психоанализ. В 1922 году Фрейд обозначает, что психоанализ это: 1) способ исследования душевных процессов, иначе почти недоступных; 2) метод лечения невротических расстройств, основанный на этом исследовании; 3) ряд возникших в результате этого психологических концепций, постепенно развивающихся и складывающихся в новую научную дисциплину [5;456]. Лапланш и Понталис в своем словаре расширяют каждый из этих пунктов. Как метод исследования он подразумевает выявление бессознательного значения слов, поступков и продуктов воображения...в основе метода лежат прежде всего, 
свободные ассоциации субъекта как гарантия надежности истолкования... психотерапевтический метод пользуется контролируемым истолкованием сопротивления, переноса и желания [5; 455]. Сегодня это понимание кажется недостаточным. Так произошло размежевание психоанализа и психоаналитических терапий, которые порой формально соответствуют фрейдовскому определению психоанализа, но нужно ли их тогда считать психоанализом?

Сейчас помимо психоанализа существует множество видов основанных на его теориях методов психотерапий. Например, итальянский психоаналитик Паоло Фонда говорит о том, что весьма сложно очертить границы и дать определение психоаналитически ориентированных психотерапий [9]. К их видам он причисляет: те, в которых систематически применяются неаналитические технические инструменты, - поддерживающие психотерапии; те, в которых классическая психоаналитическая техника модифицирована для лечения психотиков и других тяжелых пациентов; краткосрочные фокусированные терапии, а также психоаналитические терапии. Последние в некоторых профессиональных сообществах отделяют от психоанализа на основе сеттинга и подготовки специалиста. К примеру, некоторые специалисты в МПА определяют следующие признаки психоаналитически ориентированной психотерапии и психоанализа:

3-5 сессий в неделю для психоанализа и меньшее количество сеансов для психотерапии (при этом в Великобритании минимальное количество сессий психоанализа в рамках МПА 4, а во французском психоанализе МПА - 3);

Длительная психоаналитическая работа без определенного срока окончания. Относительно ограниченные и определенные сроки для психотерапии;

Внимание в психоанализе сосредоточенно на переносных отношениях в психоанализе и на внешней жизни и интернализированных отношениях - в психоаналитической психотерапии; 
В психоанализе центральные интерпретации строятся вокруг переноса, придается особая важность контрпереносу, а в психотерапии они не имеют центрального характера.

В психоанализе поощряется невроз переноса, что достигается с помощью частоты сессий и кушетки, которые способствуют регрессии, необходимой для него. В психотерапии это не поощряется.

Психоанализ приводит к проработке глубинных слоев психики, наиболее примитивных интернализованных объектных отношений, чего не происходит в психоаналитической терапии.

Вероятно, если отталкиваться от этого как от некого подобия символа веры о том, чем является психоанализ, то существенная часть наследия Фрейда будет не психоанализом, практика лаканианского и «отношенческого» психоанализа будет признаваться не-психоанализом, и конечно же психоанализом не будет считаться работа онлайн. Конечно же, вышеописанный взгляд не является консенсусом в рамках МПА, но в определенной мере широко распространен в рамках этой организации и за ее пределами.

Давайте отойдем от МПА и еще раз обратимся к Фрейду, и посмотрим, что он считал неприемлемым для психоанализа. В 1918 году после кровопролитной войны в Европе Фрейд размышляет о том, как можно модифицировать психоанализ, чтоб помогать более широкому кругу людей, которые в то время преимущественно страдали от военных неврозов. Фрейд пишет: «весьма вероятно, что при массовом применении нашей терапии нам придется сплавлять золото анализа с медью прямой суггестии...» [10]. Именно, суггестия и позиция, которая позволяет ей существовать, является одним из вариантов примесей, который лишает психоанализ его особенного положения в сонме пси-практик. Именно, эта позиция и отделяет психоанализ с его этической строгостью от психотерапии и ее психоаналитических вариаций. Вслед за Лаканом, мы можем 
сказать, что без этой этической строгости «всякое лечение, каким бы психоаналитическими познаниями оно начинено не было, остается всего-навсего психотерапией» [4; 464]. Виктор Мазин говорит, что психоанализ и есть этика [7; 73]. Это конечно же лозунг, поэтому это не совсем так, но у психоанализа есть этика и эта этика - это место в общественной связи, которую мы именуем психоанализом, которая не позволяет судить другого и принимать за него решения, т.е. это анти-суггестия.

\section{Психоанализ по ту сторону нормативности}

Каково же не-суггестивное место психоаналитика? По словам Сержио Бенвенуто magnum opus психоанализа заключается именно в том, чтобы стереть различия между нормой и патологией [2; 89]. Поддаться идеологиям о нормальности, о надлежащем поведении и чувствах - это однозначно тому, чтобы встать на сторону унификации субъекта, совершить очередной акт его отчуждения. Когда психоаналитики ориентируют свою практику на нормализацию, на здоровье - они рискуют стать проводниками того, что Мишель Фуко называл биополитикой, превращая психоанализ в дисциплинарную практику. Идея адаптированности и нормы чужда некоторым направлениям психоанализа.

Нейтралитет аналитика запрещает ему принимать сторону норм. Вместо того, чтобы защищать или критиковать эти нормы - роль аналитика состоит в том, чтобы выявить их влияние в истории субъекта. Нормализация близка к внушению, в котором аналитик теряет свою позицию и становится агентом истины.

Айтен Юран выстраивает последовательность изобретения психоаналитической этики, как уже было сказано, важнейший пункт - это приоритет психической реальности над объективной. Именно, это отличает психоанализ от психотерапии, где терапевт - это проводник истины о действительности, мерило этой истины. Производство истины для психиатра или психотерапевта не стоит, так как она уже дана объективно. Поверив истеричкам, Фрейд стал на другую позицию, он усмотрел за 
«маскарадом» истину бессознательного. Фрейд признает за симптомами и бредом смысл, смысл сингулярный свойственный только этому пациенту.

Таким образом, психоаналитическая этика не подразумевает этику, которая нацелена на достижение идеала. Каким бы представлением о благе не руководствовался специалист - в пространстве психоанализа о своем благе знает только анализант, а психоаналитик не должен встраивать его в свои представления о благе - здоровье, зрелости, уровне организации и т.д. Это обеспечивается специфичностью психоаналитического дискурса, который и является кадром психоанализа.

\section{Дискурс психоаналитика}

Лаконично о дискурсе в теории Лакана сказала Павло Швед: «Дискурс для Лакана означает не просто речь, а определенный тип общественной связи, выраженный в речи, то есть определенную субъективную позицию, которую человек может занять в речи по отношению к другим людям, а точнее к совокупности всех людей, которую Лакан обозначает понятием большого Другого. То есть это своеобразный способ бытия человека в языке, а значит и в мире (поскольку для Лакана человек является parlêtre - речесуществом), определенный способ конституирования им своего наслаждения по отношению к другим. Иными словами, речь идет о фундаментальном отношение человека к миру других людей» [11; 138].

Дискурс - это социальная связь. Это модальность, в которой выстраивается отношение человека к фантазму. Социальная связь изначально способствует выживанию и получению удовольствия. Удовольствия не бывает без социальной связи, они обретают формы благодаря нее и это справедливо для самых разных вкусовых предпочтений: от музыки и еды до политических взглядов и профессии. Удовольствие всегда связано с культурой. В природе желания не существует естественного порядка удовольствия, а когда удовольствие терпит неудачу, 
то это приводит к формированию симптома. Влечения происходят и удовлетворяются в теле, но внешний объект для него культурально детерминирован. Обозначен опытом пребывания человека в изначальной ситуации зависимости от Другого, когда человек из матки попадает в матку социума, имея возможность выживать лишь в связи с ней.

Другое, о чем нужно помнить, подходя к теории дискурса Лакана, так это то, что в отличие от большинства теорий, которые бытуют сегодня в гуманитарных науках, где слово «дискурс» является часто просто синонимом текста, нарратива или совокупности приемов аргументации, которых может быть бесконечное множество - Лакан использует это слово в крайнее специфической манере и говорит всего о четырех дискурсах: господина, истерика, университета и аналитика (также Лакан говорит о дискурсе капиталиста, или постмодерна). Я предлагаю по большей части следовать этой логике, но с определённым методологическим отступлением.

Психоаналитик в дискурсе аналитика - это знание о существовании бессознательного, но это знание не знается и это истина аналитика. Аналитик находится в позиции нехватки, так как ничего не известно о бессознательном анализанта. Исходя из этой нехватки он обращается к субъекту, требуя от него производство означающих, которое объяснит нехватку (что конечно же невозможно и в этих прорехах и раскрывается бессознательное). Производством означающих занят анализант, а аналитик - это то, кто слушает его речь. Так или иначе, но аналитик возвращает ему - «вы сказали это». В другой плоскости психоаналитического процесса, субъект, т.е. анализант, находиться на месте истерика, который обращается к своему Господину, но в анализе Господин не отвечает. Место аналитика - это безмолвие перед жалобой истерика. Место аналитика - это место объекта причины желания.

Из анализа мы знаем, что субъект, который знает свои означающие, которым он подчинен - узнает, чего ему недостает. 
В анализе он говорит о своих фантазмах, о том как бы он хотел быть наполненным, с помощью этого становиться понятна его тотальная цель, субъект обретает изобретение обращения с ним, как результат - субъект больше не заложник жалобы и не заключен в ней, субъект уже не жалуется Другому и не просит, чтоб он заполнил его фантазм. Субъект соглашается с тем, чтоб быть в желании и даже бороться за удовольствие, но больше не мечтает о наслаждении.

Существуют социальные стереотипы о том, что нужно узнать свое хотение и затем его можно воплотить, но о хотении и возможно говорить только в связи с тем, что его невозможно реализовать. Доминирующий сегодня дискурс капиталиста провозглашает автономность субъекта, а социальный порядок предлагает ему реализоваться в акте, поэтому ответственность за невозможность полной и всесторонней реализации себя возлагается на индивида [6; 120]. Анализанты к нам приходят для того, чтобы стать эффективными в дискурсе капиталиста, но уходят свободными от его предписаний.

\section{Этика верности желанию и влечение жизни}

Не смотря на позицию нейтральности, а скорее даже исходя из нее, когда только такая позиция является гарантом уважения изобретения анализанта - Лакан, по словам Бадью, не был безразличным к людским судьбам и не проповедовал цинизм, а как раз наоборот, он как Фуко и Альтюссер, боролся за дело намного последовательнее современных борцов «этики» и «прав человека»... Лакан придавал особое значение борьбе против «нормативных» направлений американского психоанализа[1;77]. Этот антинормативный, освобождающий аспект понимание этики психоанализа - явно не охватывает все его варианты и даже не является сутью этики психоанализа Лакана. Но что единит все парадигмы психоанализа? Сержио Бенвенуто говорит об идеологии психоанализа, что все направления психоанализа объединяет идеологическая позиция быть на стороне влечения жизни (и сразу же поправляет, 
что лаканианцы с ним вероятно не согласятся в этом, а мы можем вспомнить, что практика не всегда тождественна манифестируемым идеалам). Я не побоюсь сказать, что быть на стороне влечения жизни - это общее в этике психоанализа независимо от направления. Но что такое этика? В этом контексте этика - это не свод правил и предписаний, это общий организующий принцип, это способ управлять бытием. Именно быть на стороне влечения жизни и является организующим принципом психоаналитического лечения в разных парадигмах. Ослабевание требований Оно и чрезмерных требований Сверх-Я, которое и является культурой влечения смерти - не является ли позицией быть на стороне жизни? В озеленённом Грином психоанализе, связывание влечений, объектализация - не является ли движением к торжеству жизни? Интеграция личности, как этическая позиция кляйниаского психоаналитика - не приводит ли к возобладанию жизни над деструкцией? Аксиологический принцип Лакана о том, чтоб не отступать от своего желания - это тоже о том, чтоб быть на стороне влечения жизни, даже если это привело Антигону к гибели. Антигона отстояла свою человечность, ведь приказ тирана не может отменять божественные законы, которые являются условием жизни. Подвиг Антигоны вовсе не об упрямстве, которое часто граничит со всемогуществом хотения, это о желании, которое всегда вписывается в закон. Быть вписанным в закон, быть верным желанию - это быть ограниченным в своем наслаждении, это тоже о торжестве сил жизни. Является ли это навязыванием жизни анализанту? Нет, так как влечение жизни привело в анализ, и именно оно в своей объединяющей силе и поддерживает аналитический процесс. Поэтому этика психоанализа - быть на стороне влечения жизни.

\section{Психоаналитический кадр и место психоаналитика}

И все-же, возможен ли психоаналитический дискурс, психоаналитический кадр в онлайн форме? Какова роль телесности в психоаналитическом процессе очно и онлайн? 
Прежде всего психоаналитический кадр, как мы увидели выше, подразумевает наделение анализантом аналитика знанием и незнающую позицию аналитика. При этом психоанализ подразумевает работу с бессознательным, сопротивлением, переносом и желанием. И эти составляющие, конечно же могут быть как в дистанционном, так и в очном формате.

Конечно же, есть аспекты переноса, которые пронизывают все общественные отношения, Фрейд пишет о переносе не только как о феномене внутри аналитического процесса, он пишет о переносе как об искаженном прошлым восприятия настоящих объектов, даже если - это не аналитик, а врач, гипнотизер, учитель. В этом аспекте перенос на аналитика начинается еще до того, как анализант пришел в кабинет или явился на сеанс по онлайн связи. Аналитик наделяется властью знания, которая неизбежно была продиктована условиями становления индивида, которая в анализе разверчивает свои инфантильные смыслы. Но мы можем говорить о специфичности переноса в психоаналитическом процессе, которая заключается в скольжении теней бессознательных желаний на поверхности места аналитика. Что это за место? Это место нереальности психоаналитика как объекта, что позволяет запустить относительно очищенное производство внутренней реальности в рамках аналитического процесса. Это место, вслед за Полем Дени, можно назвать анти-объектом - персоной, которая отказывается быть инвестированной продолжительным стабильным образом другим субъектом и способную предоставить ему прямые удовлетворения [3; 42]. Но, так как место психоаналитика - это не просто театр теней анализанта, а экран со своей поверхностью, то проявленное в анализе бессознательное не является индивидуальным, или коллективным, а как говорит Назио - оно производиться в промежутке (L`entre-deux), как уникальная сущность, проходящая и охватывающая и одного и другого участника анализа. С одной стороны - это позволяет сформироваться искусственной болезни, 
когда аналитик становиться частью симптома, а с другой стороны, занимая место неподобного подобия и никогда не застывая, а разрешаясь в толковании - эта искусственная болезнь, или невроз переноса, позволяет трансформировать самого себя и создать новые способы обращения психики самой с собой и внешним миром за пределами аналитического пространства, таким образом производя терапевтический эффект. В этом плане у бессознательного и переноса есть специфические ипостаси, которые существуют исключительно внутри аналитического лечения.

Суть аналитического лечения состоит в том, чтоб аналитик занимал место анти-объекта и объекта. Место аналитика в качестве анти-объекта позволяет скользить означающим, позволяет производству бессознательного. С другой стороны, место психоаналитика как объекта - это место аналитика, как субъекта, который и может засвидетельствовать бессознательное, указать на точку, где сказано больше, чем хотел сказать анализант, аналитик указывает на истину субъекта.

Таким образом, можно сказать, немного переиначивая Назио, (утверждающего, что бессознательное - это производимая интерпретацией аналитика инстанция, которая разделяется обоими партнерами по анализу и известна нам исключительно из аналитической работы [8; 45]), что аналитическое лечение позволяет производству специфического состояния бессознательного и переноса, которое и оказывает терапевтический эффект. Будет ли это производство в случае дистанционного формата? Однозначно - да, я думаю, что практика большинства из нас подтверждает это. Будет ли это производство тождественным очной работе? Однозначно нет, как не тождественна работа с кушеткой и без, напрямую аналитика и анализанта или через посредника (как было в случае с маленьким Гансом), как не тождественна работа в видео или аудио формате, как не тождественна работа с разными анализантами и даже с одним и тем же анализантом на разных сессиях. Будут 
ли некие характеристики повторяться? Разумеется! И каждый фактор нам предстоит изучить. Нам предстоит понять роль либидинального тела на кушетке и в кресле, по видеосвязи и аудиосвязи. Нам предстоит понять роль физического присутствия аналитика, которая часто питает перенос, сопротивление и желание. Нам предстоит понять роль скопического и голосового влечения, роль физического пространства и средств аудио/видео коммуникации. Нам предстоит сформулировать взгляды и аргументы о том, как аналитик и анализант могут использовать чередование форматов для поддержки аналитического процесса. Скорей всего, сейчас мы находимся в моменте появления ответов на эти и другие вопросы, и в ближайшее время нам предстоит их собрать и осмыслить.

\section{Литература:}

1. Бадью А. Етика. Нарис про розуміння зла - Київ: Комубук, 2016

2. Бенвенуто С. Перверсии. Сексуальность, этика, психоанализ - СПб.; Скифия-принт, 2016

3. Дени П. Контр-перенос в кадре и отклонениях - М. Институт Общегуманитарных Исследований, 2020

4. Лакан Ж. «Варианты образцового лечения», «Я в теории Фрейда и технике психоанализа» (Семинар, Книга 2 (1954/55)), Пер. с французского А. Черноглазов. Москва; Издательство «Гнозис», Издательство «Логос», 2009.

5. Лапланш Жан, Понталис Жан-Бертран «Словарь по психоанализу» - СПб.: Центр гуманитарных инициатив, 2010

6. Лесур С. Либерализм и общество (без) симптома - Журнал «Психоанализ», Киев; МИГП, 2015

7. Мазин В. Введение в Лакана - Нежин: ООО «Видавництво АспектПоліграф", 2010

8. Назио Х.-Д. Пять уроков по теории Жака Лакана - М.: Институт общегуманитарніх исследований, 2015

9. Фонда П. Некоторые размышления о двух сессиях в неделю, Журнал Практической Психологии и Психоанализа: 2001, №3

10. Фрейд 3. «Пути психоаналитической терапии»

11. Швед П. «3 чого нам дозволено сміятися?» та інші есе - Київ: Комубук, 2020 
DOI

\section{Оксана Аршевская-Герен}

Психоаналитический психолог, клинический психолог, член и эксперт по этическим вопросам Дивизиона "Психоаналитическая психология и психотерапия" Национальной психологической ассоциации Украины https://orcid.org/0000-0002-6991-0040

\section{ОЦЕНКА ЭТИЧНОСТИ ПСИХОАНАЛИТИЧЕСКОЙ ПРАКТИКИ ОНЛАЙН РАЗНЫМИ ПРОФЕССИОНАЛЬНЫМИ СООБЩЕСТВАМИ}

В наше время наблюдается значительный и постоянно растущий рост предоставления психологической помощи на расстоянии. Быстрое развитие Интернета сделало акцент на необходимости пересмотра профессиональной практики с точки зрения этических принципов. Главный вопрос заключается в том, вводит ли психотерапевтическая работа с использованием новых средств коммуникации принципиально отличные этические вопросы, или существующие этические принципы и стандарты работы лицом к лицу, сформулированные в этических кодексах ассоциаций, подходят для их использования в новом онлайн пространстве.

При сборе информации по вопросу этической позиции различных психоаналитических сообществ, изучая их сайты, я отметила, что результаты моих исследований можно было разделить на несколько групп.

На одних сайтах одних сообществ этические кодексы есть в открытом доступе, но не содержат никаких принципов онлайн работы (например, IPA (МПА), 2015; EPF (Европейская Психоаналитическая Федерация). 
Другие сообщества представили свои этические кодексы только в ПДФ формате на языке их государства, что делает их недоступными для свободного ознакомления (Израиль - на иврите, Дания - на датском), а следовательно, невозможно сделать какой-либо вывод о наличии/отсутствии освещения этих вопросов.

Третьи вообще не имеют на своих официальных страницах упоминаний об этических принципах и документах, что заставляет подумать, конечно же, не о том, что их не существует, а скорее о том, что они размещены на закрытых зонах сайта, куда имеют доступ только зарегистрированные члены этих сообществ.

При этом и сама IPA (МПА), и ее члены (не все, большинство вообще обходит этот вопрос молчанием, но, например, Швейцарское ПА сообщество) упоминают о психоанализе на расстоянии не в разделе Этики, а в рамках описания обучающих процедур, устанавливая дистанционные встречи не как основной тренинговый аналитический процесс, а только как вспомогательный.

IPA обозначает процесс удаленного анализа в обучении как экспериментальный, возможный только в исключительных обстоятельствах и требующий индивидуального согласования и дополнительных исследований, описывая его в рамках Дополнений в Процедурный кодекс:

«...5. Перед началом удаленного анализа обучающий аналитик должен:

а. осознавать проблемы, связанные с этой модальностью, и учитывать способность кандидата продолжать работать таким образом, например, ранняя травма и разлука могут указывать на потенциальные трудности с этим способом анализа.

б. Убедитесь, что второе собеседование проведено независимым обучающим аналитиком, чтобы убедиться, что анализ не противоречит клиническим или этическим показаниям. 
Это должно позволить тщательно оценить психическое функционирование кандидата и его защитную систему, а также способность кандидата пройти через этот удаленный фрейм.

с. учитывать влияние технологий и экспериментальный характер предприятия.

d. Убедитесь, что кандидат свободно владеет языком, на котором будет проводиться анализ, как с точки зрения понимания, так и с точки зрения разговорной речи.

е. обратитесь за консультацией к старшему коллеге по их «удаленной» аналитической работе.

f. узнайте о социокультурном контексте страны происхождения кандидата.

g. проверить свою способность работать удаленно. Опытные аналитики с безопасными внутренними настройками и надежными аналитическими данными лучше подходят для удаленной работы и могут лучше противостоять изменениям внешних условий.

h. убедитесь, что обе стороны удовлетворены безопасностью выбранного метода удаленного анализа...»

«...Существуют проблемы, связанные с безопасностью, защитой конфиденциальности и конфиденциальностью по всем видам телекоммуникаций, включая фиксированные и мобильные телефоны, приложения VolP, электронную почту и любые другие приложения, использующие Интернет. Эти проблемы необходимо учитывать, и аналитики / пациенты / супервизии должны знать о них до начала лечения. Аналитики должны убедиться, что они понимают пределы безопасности, обеспечиваемой технологией, которую они и их пациенты используют, а также пределы их возможностей по защите конфиденциальности пациента. Им следует знать, что при психоаналитической работе, проводимой с использованием телекоммуникаций, как и в офисе, конфиденциальность пациента не может быть гарантирована». 
IPA подчеркивает индивидуальную способность работать таким образом, связанную с детской травмой, необходимость учитывать социокультурный контекст, иметь ввиду возможные пределы безопасности и конфиденциальности, обеспечиваемые выбранной технологией связи.

Помещая информацию о дистанционной работе не в этический кодекс, а в раздел о тренинговом анализе, что подразумевает IPA? Возможно ли практиковать дистанционный анализ при помощи современных средств коммуникации за рамками обучающего анализа, с клиентами, нуждающимися в психологической помощи, но, в силу тех или иных причин, не имеющими возможности или желания посещать психоспециалиста очно?

На эти вопросы IPA не дает своей официальной этической позиции. Я процитирую: «Эта запись об изменении предназначена только для справочной информации и не является частью Прочедурного кодекса. Если есть какой-либо конфликт между утверждением в Процедурном кодексе и утверждением в этой записи об изменении, запись об изменении не будет приниматься во внимание».

Наиболее полно и развернуто на вызов онлайн-реальности отвечает ЕАР - Европейская Ассоциация Психотерапии:

\section{“Временные советы по проведению психотерапии онлайн}

В ответ на пандемию Covid-19 многие терапевты рассмотрят возможность работы в Интернете со своими клиентами для поддержания терапевтического контакта, но сводя к минимуму риск для обоих - для клиента и терапевта.

«Онлайн-терапия» обычно относится к четырем форматам: телефон; видео-конференция; электронная почта терапия; и мгновенный обмен сообщениями (І.М. или «текстовый чат»).

Существуют убедительные доказательства того, что онлайн-психотерапия эффективна, но не для каждого клиента или терапевта. 
И пока онлайн-терапия использует те же теоретические концепции и многие практики, традиционно используемые в личной терапии (F2F), есть и отличия - так же, как есть различия, скажем, между индивидуальной терапией и терапией для пар.

Этот документ предназначен для обозначения некоторых вопросов, которые вам нужно будет рассмотреть, если вы не очень много работали в сети. Это руководство предусмотрено как временная мера и не должно рассматриваться как полное обучение.

Его подготовил Адриан Роудс, бывший президент ЕАР и в настоящее время председатель «Ассоциации онлайнконсультирования и терапии» (Великобритания). Это не исчерпывающий документ; дальнейшие изменения будут внесены в Совет ЕАР для рассмотрения и ратификации.

\section{Оценка}

Оценка трудна и требует особого внимания.

Те, кто не знаком с онлайн-работой или не имеет специальной подготовки, должны быть более осторожны, когда осуществляют прием онлайн-клиентов.

В частности, вам придется обратить внимание на:

- Риск - как оценивать, отслеживать и реагировать на:

- риск самоубийства и членовредительства;

- потенциального вреда для других;

- риск для клиента от кого-то другого;

- наличие личной поддержки

- необходимость сбора местной информации для ответа на любые потенциальные риски.

- Психологический профиль клиента:

- Сила эго

- Употребление наркотиков и алкоголя

- Депрессия

- Расстройства личности и т. д. 
- Вам нужно будет тщательно продумать, какие контактные данные вам понадобится иметь, - в том числе медицинских или социальных специалистов в месте проживания пациента.

\section{Конфиденциальность и безопасность}

- Skype не считается безопасным способом общения с пациентами.

См. «Хорошее руководство по Skype» по адресу: https: //acto-org.uk/faq/

- Многие онлайн-терапевты используют Zoom.us (https: //zoom.us/), поскольку он очень безопасен.

- Он соответствует очень высоким стандартам «НІРАA» правовой системы США для онлайн-безопасности (https://www.hhs.gov/hipaa/for-professionals/index.html);

- Zoom предлагает бесплатную услугу, которая позволяет проводить индивидуальные встречи;

- Клиентам не нужно устанавливать Zoom на свои компьютеры.

- Вам нужно будет напоминать своим клиентам:

- Найдите уединенное безопасное место для сеансов (не в баре или такси!);

- Убедитесь, что другие не могут слышать звук или видеть экран;

- Остерегайтесь говорить слишком громко в наушниках;

- Обсудите со своим клиентом, можете ли он или вы записывать сессии. Если договоренность о записи сессий достигнута, они должны вести запись в безопасный, защищенный файл

- Они могут пожелать очистить историю браузера, электронную почту или текстовые сообщения после того, как

сеанс терапии, чтобы никто не нарушал их конфиденциальность.

- Вам также необходимо будет вести записи, компьютерные заметки, контактные данные и т. д.в безопасных защищенных 
файлах - как если бы вы сохраняли физические заметки в запертом кабинете.

- Вы должны использовать безопасный адрес электронной почты, например Hushmail (https: //www.hushmail.com/) или ProtonMail (https: //protonmail.com/)

\section{Договор}

Возможно, вы захотите переписать свой контракт, чтобы покрыть онлайн-работу:

- Чтобы ваш клиент дал согласие на работу в Интернете и какая форма терапии;

- указать, что работа регулируется правовой системой вашей страны;

- И что работа регулируется вашим компетентным органом по вопросам этики и рассмотрения жалоб (и дайте ссылку).

- Вы должны указать, что вы не можете оказывать «неотложную» помощь и

подтвердить, что они знают, как получить доступ к этому локально;

- Вам нужно будет обратить внимание на подробности «контакта по вопросам безопасности».

- Чтобы указать, как будет производиться оплата:

- Рекомендуется предоплата;

- Некоторые предлагают разные тарифы или скидки на бронирование для работы в Интернете;

- Клиенты могут иметь право отказаться от онлайн-услуг в определенное время.

- Вы можете заключить договор, что сохраняете право собственности на любые «Запись» сеанса (видео, электронные письма, тексты).

\section{Вопросы «управления»}

- Вам необходимо убедиться, что ваша страховка (или страховка работодателя) покрывает онлайн работу - особенно если она международная; 
- Убедитесь, что в вашем профессиональном органе или государственной правовой системе нет конкретных правил / законов, регулирующих работу в Интернете;

- Если вы работаете за границей, вам необходимо проверить, есть ли законы в этой стране ограничение практики психотерапии.

- Вам нужно будет обновить (или создать) «Конфиденциальность» и «Социальные сети», то есть политики, которые распространяются на работу в Интернете.

- [См. мои: http://adrianrhodes.net/social-media-policy/ и http: //adrianrhodes.net/privacy-policy/ ]

\section{Технические неисправности}

- Вам (и клиенту) потребуются (в зависимости от используемых вами носителей):

- Компьютер, планшет, смартфон (не рекомендуется) - с:

- Камера, микрофон;

- Возможно наушники.

- Достаточная «широкополосная ширина» интернета или сигнал 4G для носителя, который вы используете.

- Убедитесь, что вы умеете использовать технологию; потренируйтесь заранее.

- Имейте «запасной план» отказа от технологии:

- Либо другое устройство, либо адрес электронной почты, либо номер телефона, который они могут использовать.

- Обратите свое внимание на конфиденциальность и безопасность сеанса с вашей стороны.

- Если вы работаете на международном уровне, проверьте безопасность Интернета в стране клиента. Хорошая информация доступна по адресу: https://en.wikipedia.org/wiki/Internet_ censorship_and_surveillance_by_country

- $и$ по правам человека проверьте https: //en.wikipedia.org/wiki/List_of_human_rights_arHcles_by_country.

- Электронная почта «асинхронна»: 
- т.е. это не "одновременный" обмен электронными письмами.

- Обычно пациент тратит «сеанс» (например, 50 минут) на написание электронного письма и отправку его терапевту, скажем, во вторник. Терапевт может прочитать его сразу, но позже (скажем, в четверг) прочтите его (еще раз) и ответьте на электронное письмо, написанное через 50 минут.

- Обмен мгновенными сообщениями (I.M. - text-chat) синхронный:

- терапевт и клиент пишут друг другу в согласованное время сеанса (скажем, 50 минут);

- если это делается прямо на смартфоне, компьютере или планшете, клиент будет иметь копию сеанса; подумайте, хотите ли вы этого;

- Если обмен мгновенными сообщениями осуществляется на защищенной платформе, такой как Zoom, вы можете контролировать любую запись;

- Больше, чем любая другая терапия, это требует умелого использования контрпереноса;

Клинические проблемы

В сети люди действуют по-разному; вам, возможно, придется адаптировать свою теоретическую точку зрения или клинические методы реагирования. В частности:

- «Цифровые аборигены», выросшие вместе с миром Интернета, намного больше знакомы с этим, чем «цифровые иммигранты», которым пришлось учиться позже.

- Вы, вероятно, потеряете некоторых клиентов, но работа с другими будет процветать и казаться даже более интимной в Интернете - особенно по телефону или при помощи немедленных сообщений.

- Эффект растормаживания онлайн означает, что некоторые люди очень быстро и более интенсивно открываются в сети. Поначалу это может показаться поразительным. (https: 
//www.researchgate.net/publication/8451443_The_Online_Disin hibited_Effect)

- В результате защита и сопротивление могут быть значительно уменьшены.

- «Разница потенциалов» будет изменена на более равное соотношение:

- Вы не будете так сильно «владеть» терапией;

- Клиенты часто более «естественны», чем в сеттинге F2F;

- Они действуют больше как «клиенты», чем «пациенты»;

- Также «свободную ассоциацию» следует рассматривать как нечто иное в Интернете:

- клиенты будут «встречаться» в своем собственном пространстве;

- они могут показать вам фотографии; артефакты и др.

- они могут «явиться» на сессию сидя в разных комнатах дома - или в саду;

- Клиенты также могут использовать домашних животных, подушки, еду и т.д. в качестве защиты;

Однако все это необходимо учитывать и учитывать, а не осуждать.

- Работа с использованием электронной почты, телефона или І.М. («текст. сообщений») может быть очень напряженной,

если все сделано правильно (и «контрперенос» особенно важен). Однако неосторожный терапевт может легко отвлечься и потерять концентрацию.

- Даже психоаналитические терапевты могут - должны - корректировать свои методы, используя различные модальности например, арт-психотерапия, когнитивно-поведенческая терапия.

- Вам нужно будет обратить особое внимание на звук, освещение и фон при использовании видео; практикуйте это глазами клиента, прежде чем начинаю работать в сети.

Терапевты могут чрезмерно беспокоиться о том, что происходит в онлайн-терапии. 
Однако все же существуют параллели с терапией лицом к лицу.

- Пациенты опаздывают и заставляют нас ждать;

- Резко уходят - выходят <> закрывая крышку ноутбука;

- пропадает сигнал <> кто-то стучит в вашу дверь;

- Они одеваются или ведут себя ненадлежащим образом. (Однажды мой пациент пришел голым на F2F сеанс при работе в стационаре!);

- Они могут оставить нас с тревогой за свою безопасность в конце занятий -как в терапии F2F, так и онлайн - и не могут «действовать».

Вам нужно будет уделить особое внимание окончанию терапии - и тому, как ваши клиенты будут поддерживаться далее.

\section{Супервизия и обучение}

Поскольку онлайн-работа во многом очень похожа на терапию лицом к лицу, терапевту легко впасть в самодовольство. Подумайте о том, чтобы найти супервизора, который знаком с особенностями работы в Интернете.

Еще лучше найти хорошее обучение работе в Интернете. ACTO (Association of counseling and therapy online / Ассоциация онлайн консультирования и терапии) рекомендует получить диплом о повышении квалификации (80 часов обучения)."

Возвращаясь к официальным позициям относительно этики работы онлайн необходимо отметить, что Этический комитет EFPA включил в свои методические рекомендации раздел по работе в Интернете (Изложенные в виде итогового отчета по Этике еще в 2001 году и названные «Предоставление Психологические услуги через Интернет и другие непрямые средства»). Кроме общих, в том числе и тех, о которых мы говорили выше (конфиденциальность, безопасность,защита информации, понимание пределов компетенции средства связи и метода терапии), эти рекомендации еще два специальных момента работы онлайн: 
- идентификация // анонимность: традиционно клиент имеет право сохранять свою анонимность, но задача психолога убедиться в правовом статусе и уязвимости клиента (речь идет о терапии детей и подростков (и других уязвимых клиентах) - необходимо согласие их опекунов на терапию).

- как и в случае с любой рекламой, психологам следует избегать преувеличенных заявлений в сети Интернет об успехах их работы.

Кроме того, EFPA рекомендовала Национальным ассоциациям разработать свои Этические руководства по проведению психотерапевтической работы в Интернет. Национальная психологическая ассоциация Украины в проекте Этического кодекса, который сейчас находится на этапе обсуждения, вынесла следующие позиции:

“Етичні особливості дистанційної/електронної психологічної практики (Е-консультування).

4.1. Дистанційна електронна психологічна практика потребує дотримання спеціальних дій для підтримки етичних стандартів в інтернет-просторі.

I) Зобов'язання освоєння спеціального курсу, після його затвердження Радою НПА, та методичних порад щодо дистанційної/електронної психологічної практики, й/та постійне оновлення знань та навичок в цій сфері/ділянці.

II) Усвідомлення обмежень щодо дистанційної/електронної психологічної практики та відповідний підбір стратегії/тактики й конкретних методів роботи.

III) Забезпечення максимально доступного рівня конфіденційності.

IV) Включення в інформовану згоду з клієнтом специфічних пунктів щодо дистанційної/електронної психологічної практики (ризики, засоби комунікації, організація простору, технічний протокол, процес взаємодії тощо). 
V) Зобов'язання проводити аудіо або відеозапис лише 3 дозволу клієнта або його законних представників.

В свою очередь Этический комитет Дивизиона “Психоаналитическая психология и психотерапия" НПА Украины посвятил несколько пунктов Кодекса Этики и Профессиональной практики особенностям как психотерапевтической работы онлайн, так и личного онлайн присутствия специалистов в соцсетях и их общения с клиентами вне терапевтическим пространством:

«... 7.5. Психоаналитики / психотерапевты понимают, что современный психоанализ живет в эпоху цифровой революции. Они поддерживают и развивают возможности, изучают правила и законы новых интернет коммуникаций, опираясь на кодекс профессиональной этики и практики.

7.6. Этический кодекс в профессиональном поле сети интернет рассматривает только взаимоотношения коллег и пациентов, так как исходит из понимания того, что психология, психоанализ и психотерапия - это профессия. Поэтому, Этический кодекс не распространяется и не регламентирует частную жизнь специалистов, которую они ведут в онлайн пространстве, за исключением случаев, когда его или ее опубликованная личная жизнь дискредитирует сам психоаналитический / психотерапевтический метод и то профессиональное сообщество, к которому он принадлежит.

7.7. Психоаналитики / психотерапевты, понимают это разделение на частное и профессиональное и воздерживаются от онлайн дружбы с клиентами. В случае, если клиентом становится тот, кто подписан на личный аккаунт специалиста, то специальным пунктом психотерапевтического контракта указывается принцип конфиденциальности: клиент воздерживается от посещения страницы своего психотерапевта в социальных сетях, не комментирует посты на его персональной странице, не читает и не комментирует его высказывания в 
контексте профессиональных дискуссий на профессиональных ресурсах. Специалист со своей стороны не приглашает пациента к дискуссии и пытается настроить свой аккаунт таким образом, чтобы его активность в социальных сетях не просматривалась клиенту.

7.8. Допустимо использовать мессенджеры в социальных сетях и других онлайн ресурсах для минимальной коммуникации с пациентом, только для решения вопросов, связанных с выполнением сеттинге и контракта.

7.9. Психоаналитики / психотерапевты осознают, что идеальной конфиденциальности в социальных сетях достичь невозможно, и поэтому все неожиданные пересечения пациента и специалиста в сетевом мире должны тщательно обсуждаться в терапии с этим пациентом.

7.11. Допускается использовать возможности интернетресурсов и другие цифровые и телекоммуникационные возможности для работы с пациентами. При заключении договора с пациентом, группой, парой или ребенком / подростком на работу онлайн, рекомендуется опираться на правила оффлайн работы.

7.12. Считается неэтичным ситуация, если во время онлайн видео-сессии только у одного из участников выключено видео. Такая ситуация ставит одного из участников терапевтической пары в привилегированное положение, тем самым нарушая базовый принцип психоаналитической / психотерапевтической практики симметричности и равнозначности, что не предусматривает доминирования. Такая неравноправное ситуация инициирует сопротивление переносу и должна быть проработана в терапии или на супервизии.

7.13. Онлайн сессия, в которой все участники не используют видео, считается телефонной сессией с помощью сети интернет. Допустимо проводить сессии, через переписку по 
электронной почте или SMS, если заключен контракт на такой вид психоаналитической / психотерапевтической работы. »

Резюмируя, хочется сказать, что если подготовленные психотерапевты решат не участвовать в новой и развивающейся области онлайн-психотерапии, вполне вероятно, что появятся шарлатаны, которые смогут удовлетворить постоянно растущий спрос, возможно, вытеснив профессиональных психотерапевтов с рынка. По этой причине психотерапевты любого профессионального образования должны быть должным образом проинформированы о рисках и преимуществах онлайн-психотерапии, если они хотят принимать обоснованные решения и действовать в наилучших интересах своих пациентов. Даже если они решат сами не предлагать такие услуги, они должны быть осведомлены для предоставления информации об онлайн-психотерапии, которая позволит пациентам принять взвешенное решение об использовании таких услуг.

Таков на сегодня обзор возможных источников информации об этических особенностях проведения психотерапевтической работы онлайн. Мне хотелось осветить как можно больше этических аспектов, которые необходимо учитывать в этой работе, и привлечь внимание профессионалов к необходимости развития этой темы, поэтому приглашаю всех к дискуссии.

\section{Литература:}

1. https://www.epf-fep.eu/page/epf-societies

2. https://ru.ipa.world/en/IPA1/Procedural_Code/Ethics_code_new.aspx

3. http://news.europsyche.org/eap_member_information_20_covid19/EAPonlineGuidance.pdf

4. https://www.ipa.world/ipa/en/IPA/Procedural_Code/Ethics_code_new.aspx

5. https://acto-org.uk/acto-guidance-on-security-and-privacy-for-therapistsproviding-online-therapy-during-the-covid-19-crisis/

6. https://docs.google.com/document/d/10iPlwzHIE74huhd-

FfTOtJNXBKPRI9oh/edit?fbclid=IwAR1GXHOtuaa4QcCQsyw5L4vp5IOucaqGKFcMUw5CT7jQ5Kg4B3ifX9UKVI 


\section{КЛІНІЧНИЙ ДОСВІД ПОЗАКАБІНЕТНОÏ ПСИХОАНАЛІТИЧНОЇ ПРАКТИКИ}


УдК 159.964

DOI

\author{
Марианна Козлова \\ Психоаналитический психотерапевт, супервизор, \\ официальный представитель ЕКПП в Беларуси, супервизор, \\ кандидат Международной Федерации Психоаналитических Сообществ (IFPS), \\ член Белорусской ассоциации психотерапевтов (БАП) \\ https://orcid.org/0000-0001-5399-7340
}

\title{
НОВЫЕ РЕАЛИИ. КАК БЫТЬ?
}

Я довольно долго размышляла над тем, что мне было бы интересно обсудить на конференции. Однажды, поздним вечером мой взгляд скользнул по томику Шекспира. Я вспомнила слова Гамлета: «Быть или не быть? Bom в чем вопрос...» И в этот момент «пазлы» сложились. Мне бы хотелось поделиться сегодня с вами своими размышлениями по поводу текущей ситуации и нашей адаптации к ней. Потому что с марта 2020 года мир резко изменился. И сейчас не стоит вопрос: быть или не быть психотерапии и психоанализу онлайн. Сейчас стоит вопрос: как быть?

Я думаю, что все вы помните времена, когда велись дискуссии по поводу работы онлайн. И многие высказывались весьма неодобрительно о данном способе. Так исторически сложилось, что мой личный опыт состоит из всех возможных вариантов. В самом начале своего пути в профессию психотерапевта я нашла специалиста у себя в Минске, и мы работали у него в кабинете. Затем было повышение квалификации в Литве. Одним из необходимых условий для получения диплома являлось наличие дидактической психоаналитической психотерапии, 
которая проходила шаттлово. Я до сих пор помню, как, приезжая каждые 2 недели к своему аналитику, первые 2 часа я просто «вываливала» все, что у меня накопилось. И лишь затем я могла работать в более спокойном режиме. Так повторялось каждый мой приезд. Я думаю, что те из вас, кто проходил терапию или анализ в шаттловом варианте, могли заметить аналогичную реакцию. Поскольку мои коллеги по учебе у себя такую же ситуацию наблюдали.

Сейчас я не помню точно, с чем именно это было связано, но после того, как нормативные 300 часов терапии были пройдены, мы с аналитиком решили попробовать работать регулярно в скайпе и продолжать встречаться во время моих приездов в Литву на семинары, как раньше. Это был первый опыт работы онлайн как для моего аналитика, так и для меня в качестве пациента. Тогда я с радостью обнаружила, что во время приездов могу работать спокойно, а не эвакуировать экстренно содержимое переполненного за время перерыва между шаттлами контейнера. Что необходимость выгружать в терапевта скопившиеся «завалы» своей психики у меня просто исчезла. Опытным путем на себе я обнаружила, что терапия онлайн работает достаточно хорошо. Да, есть разница между удаленной терапией и работой в кабинете. Но так ли принципиальны различия? Как плюсы, так и минусы есть в каждом варианте. Нам может нравиться или не нравиться работать онлайн, но без использования интернета работать сегодня уже невозможно. И именно об этом я хотела бы сегодня поговорить с вами, уважаемые коллеги.

Сегодняшний мир таков, что основные коммуникации переносятся в киберпространство. Дистанционные технологии используются очень широко и уже более 50-ти лет. Хотя, если немного погрузиться в историю, то появление дистанционного образования начинается с XVIII века. В 1728 году Калеб Филипс подал в бостонскую газету объявление о наборе студентов 
для изучения стенографии в любой точке страны путем обмена письмами. Это послужило началом образования на расстоянии. В 1892 году, университет Чикаго создал первую дистанционную программу, став тем самым, первым дистанционным учебным заведением США.

С изобретением радио процесс разработки обучения на расстоянии ускорился, стали доступны новые формы работы с учащимися. Считается, что первый университет, который внедрил радио в обучение, был Государственный Университет Пенсильвании, в 1922. С появлением телевидения в 1950-х годах развились телевизионные курсы.

В 1960-е годы дистанционное образование получило международное признание и стало активно развиваться при поддержке ЮНЕСКО. В 1963 году премьер-министр Англии Г. Вильсон объявил о создании «эфирного университета», который предполагал объединить все учебные заведения, использующие дистанционное образование. Университет Висконсина в США в 1965 году внедрил масштабную образовательную программу для врачей, используя при этом формат телефонного преподавания. В 1968 году можно было получить аккредитованный диплом на базе дистанционного образования в университете Линкольна, штат Небраска. Дистанционные технологии в обучении начали довольно широко применять с 1969 года, когда был основан 1ый в мире Университет дистанционного образования - Открытый Университет Великобритании (он был назван так, чтобы показать его доступность за счет невысокой цены и отсутствия необходимости часто посещать аудиторные занятия).

С изобретением интернета человечество шагнуло еще на шаг вперед в образовательных технологиях. На сегодняшний день есть ряд платформ, которые позволяют получать онлайнобразование. Наиболее известные из зарубежных - это Coursera, Udemy, edX, а также российский Skillbox. И сейчас 
дистанционные технологии используются практически повсеместно, в том числе в психотерапии и психоанализе. Мы работаем с пациентами в скайпе, даем и берем супервизии, используем различные платформы для семинаров и обучающих программ. Посредством интернета мы поддерживаем связи с профессиональными сообществами. Как на постсоветском пространстве, так и за рубежом есть центры обучения психоанализу и психотерапии, которые предлагают весь спектр тренинга. Не только обучение, а и тренинговую терапию или анализ, супервизии и групповую работу в онлайн пространстве. Современный мир буквально пронизан технологиями и они становятся неотъемлемой частью нашей жизнь.

К слову сказать, в свое время я с удивлением прочла сообщение в интернете, что, как оказывается, в секс-индустрии очень активно используется общение веб-моделей и пользователей в видеочате в режиме онлайн. Я не буду сегодня останавливаться на этом, но у меня эта информация вызвала много вопросов и размышлений.

Что касается психотерапевтической работы онлайн, то она имеет как плюсы, так и минусы. И для начала я хотела бы остановиться на очевидных бонусах, которые мы имеем.

Пациент, особенно, если это будущий психотерапевт, может выбирать специалиста без привязки к своему месту жительства, что позволяет снизить риск или совсем избежать пересечений контекстов. Я думаю, что это значимый фактор в нашей работе. Ведь даже в больших городах психотерапевтические сообщества не так уж и велики.

Если взять Беларусь, то психотерапия начала развиваться здесь всего пару десятков лет назад. И около половины этого времени, кроме терапевтической работы у себя в Минске, я занималась организацией конференций, обучающих программ, Летних школ по психоанализу и психотерапии и различных групп. Побочным последствием моей деятельности 
явилось то, что многих психотерапевтов я знаю лично. И когда мой сын решил начать психотерапию, мне пришлось обратиться к моему супервизору в Литве за рекомендациями, чтобы избежать пересечения контекстов. Для меня было крайне важно найти специалиста, с которым я лично не знакома, и который при этом достаточно хорош с точки зрения уважаемого мной профессионала. Особенно с учетом того, что я на себе прочувствовала не самые приятные последствия, которые возникли из-за невозможности избежать смешения контекстов в начале моей профессиональной деятельности.

Принадлежность к одному психотерапевтическому сообществу приводит к сложной плоскости пересечений. Участие в семинарах, различных группах, конференциях неминуемо сводит нас с теми, с кем мы работаем, если это будущий психотерапевт. И тогда зачастую мы оказывается перед необходимостью делать крайне сложный выбор: или отказываться от участия в интересующем нас мероприятии, или в течение определенного времени прорабатывать и перерабатывать в терапии последствия таких пересечений. Всего этого можно избежать при использовании дистанционных технологий.

Интернет позволяет нам работать из любого места и из любой точки мира, что само по себе очень удобно. Если пациенты не успевают добраться домой, то они могут выйти на связь, сидя в машине, и не опаздывать к назначенному времени встречи. Или могут таким образом уединиться, если их домашние во время сессии находятся дома. Отпадает необходимость делать перерыв в терапии, когда пациент уезжает в командировку или отпуск, что было неизбежным при встречах в кабинете. Таким образом, мы получаем больше возможностей и степеней свободы, когда работаем онлайн.

Используя скайп, появляется шанс обеспечить постоянство и регулярность терапии. И по моему опыту, это значительно облегчает течение процесса по сравнению с шаттл- 
терапией. Кроме этого, поскольку на экране монитора невербальные проявления видны все-таки хуже, мы тренируемся лучше слушать и слышать, о чем говорит пациент, и становимся более внимательны к словам и смысловым оттенкам.

При дистанционной работе имеется еще и довольно приятный материальный плюс - это экономия времени и денег на трансфере. При чем как для пациента, так и для психотерапевта, если его кабинет находится не рядом с домом. Ведь за то время, которые мы тратим на дорогу к кабинету, особенно в мегаполисах с их пробками и расстояниями, можно принять еще одного-двух пациентов, или освободить себе время для других дел. Например, написать доклад на конференцию, прочесть статью, пообщаться с коллегой или просто отдохнуть.

В то же время, терапия онлайн имеет ряд «побочных» эффектов. Еще в 2014 году John O’Keefe, May Britt, Edvard Moser, исследуя работу мозга, обнаружили, что в нашем общении всегда задействовано и то пространство, на котором оно происходит. При работе в кабинете в мозгу остается «привязка» к обстановке, в которой находятся пациент и терапевт. И на сегодняшний день мы не знаем, как повлияет отсутствие этой дополнительной связи на процесс терапии. Может быть это обернется к лучшему, а возможно, мы что-то безвозвратно потеряем.

Также мы знаем, что терапия начинается не тогда, когда пациент садится в кресло или ложится на кушетку. Она начинается еще по дороге в кабинет. И ученые подтвердили, что одни и те же нейронные сети отвечают как за перемещение тела в пространстве, так и за путешествия в пространстве памяти, мыслей и чувств. Наш мозг содержит ментальную карту, которая помогает нашим перемещениям. И она включает в том числе наши впечатления и запахи (Buzsaki \& Moser, 2013).

Когда мы пользуемся традиционными, выработанными тысячелетиями способами общения, то включенность в диалог, его воздействие на нас, а также наша ответная реакция довольно 
интенсивны. С использованием интернета мы менее активно участвуем в общении, чем это заложено эволюционно. Наличие совместного пространства оказывает влияние на то, как именно проходит общение и влияет на его качество.

В своей работе мы имеем дело с внутренней реальностью. И большую часть ее составляют эмоции. Известно, что основные эмоции человек «читает» и распознает не столько по произносимому тексту и мимике, сколько по телодвижениям собеседника. В ответ «включаются» собственные эмоциональные реакции. Экспериментально было установлено, что на эмоциональность общения у испытуемых влиял тот факт, где именно находится партнер по общению - в соседней комнате или в другом городе. И я думаю, что психотерапевты не являются исключением. Мы также более эмоционально включены при близком контакте, хотя это не всегда можно за собой отследить.

Когда мы общались с коллегами на тему состояния и самочувствия во время онлайн терапии, можно было услышать противоположные отклики. Кому-то работать стало легче. Ктото говорил о большей усталости из-за напряжения. Общим было то, что взаимодействие отличается от привычного в кабинете, и что появилась необходимость обустроить работу технически, чтобы это было удобно.

В онлайн работе есть составляющие, которые так или иначе, в большей или меньшей мере имеют значение и оказывают влияние на нашу работу. И мне хотелось бы поделиться своими размышлениями по этому поводу.

К значимым факторам, влияющим на происходящее в сессии, я бы отнесла в первую очередь отсутствие сенсорного контакта. Это неотъемлемая черта онлайн-терапии, которая находится вне зоны нашего влияния и это невозможно исправить. При работе в скайпе мы видим не целостную картинку, а только ее часть, и это может приводить к функциональным искажениям в восприятии. Например, когда терапевт улыбается, 
то пациент может улыбаться ему в ответ и при этом сжимать кулаки. При работе в кабинете мы бы обратили внимание на это несоответствие и стали бы размышлять о возможных причинах. Когда же такие детали остаются вне зоны видимости, специалист может только смутно ощущать, что происходит нечто, чему практически невозможно найти объяснение.

Встречаясь в скайпе, мы не чувствуем запаха, цветопередача временами искажается монитором и тогда легко упустить нюансы, которые были бы очевидны для нас при работе в кабинете. Та чашка, из которой пациент что-то пьет во время сессии - что в ней? Это кофе, вода или там алкоголь? Мы этого не знаем. Хотя при очной встрече легко бы почувствовали запах и определили. При встрече онлайн пространство и пациент целиком не видны для нас. И существенные детали могут ускользать, поскольку находятся вне поля зрения, однако при этом нередко вызывают эмоциональный диссонанс у терапевта и непонимание, что же происходит с пациентом. А когда идет работа в переносе, то такие мелочи имеют большое значение.

Также к имеющим значение факторам я бы отнесла отсутствие возможности во время нашей работы влиять на условия, в которых находится наш визави по ту сторону экрана. В кабинете, как правило, мы можем обеспечить безопасность и подходящую обстановку. Когда же работа происходит онлайн, то контроль за ситуацией осложнен. В какой-то момент мы можем увидеть собаку или ребенка, который мелькает на экране. И только тогда обнаружить, что, оказывается, мы работали втроем, а не вдвоем, как думали изначально.

Случается, что пациент во время сессии держит ноутбук или смартфон у себя на коленях, или выходит в скайп, сидя в постели. Такие ситуации не всегда возможно отследить. И тогда голова терапевта располагается по отношению к пациенту совершенно не там, где она была бы при работе в кабинете. Говорящая голова на коленях или в постели - довольно 
пикантная ситуация. И бессознательное пациента реагирует на такое положение. А поскольку мы не видим картинку целиком, то происходящее в сессии может вызвать диссонанс у терапевта. Невольно возникает вопрос: как с этим обходиться?

То же самое касается и курения во время сессии. В своем кабинете я устанавливаю правила. Когда идет работа в скайпе, то есть наше общее время, предназначенное для работы. В то же время, есть 2 территории, и одна из них нам не принадлежит - не мы являемся на ней хозяевами. Подобные феномены можно и желательно исследовать, пытаться понять, что именно за этим кроется. Но увы, это не всегда осуществимо. И приходится держать ситуацию у себя в голове, что является дополнительной нагрузкой для нас, как специалистов.

Бывает, как во время сессии мы замечаем, что взгляд пациента скользит по экрану или направлен куда-то в сторону. И тогда можно предположить, что кроме работы с нами, он занят еще чем-то. Лично я временами делаю заметки во время сессий. При работе в кабинете пациент это видит и понимает, что происходит. При работе онлайн я информирую, что могу смотреть вниз, когда записываю, и при этом слушаю и слышу, о чем идет речь. Для того, чтобы не усиливать тревогу, приходится пояснять и запоминать довольно много дополнительной информации.

Все эти важные детали, на которые мы не можем существенно повлиять, приводят к эмоциональной неуверенности, которая осознается терапевтом только частично, т.к. внимание концентрируется на других вещах. Эта неуверенность становится сильнее при обсуждении эмоционально важных для пациента вопросов. Она же приводит к тому, что быть естественным не так легко, как при работе в кабинете. И говорить о сложных вопросах, углубляться в противоречия или интерпретировать может быть тоже непросто. Возможно, что все вышеперечисленное и приводит к тому, что при работе онлайн у многих специалистов быстрее наступает усталость. 
Также невозможно игнорировать тот факт, что скайп становится вечным третьим в нашей работе. И техника может вмешиваться в терапевтический процесс. Временами случаются проблемы с интернетом. Как это было в августе 2020 во время протестов в Беларуси, когда его просто отключали на неопределенный срок. Бывают чисто технические сбои с одной либо другой стороны. В кабинете мы просто сидим и ждем пациента, т.к. это его время. Наша задача - наблюдать за происходящим. При работе в скайпе возникает беспокойство: это техника подвела или пациент не появился? Он там или его нет? Что за причина? Я уже не говорю о том, что есть техника разного качества и не всегда она достаточно хороша, что приводит к искажениям изображения или голоса. Тогда нам приходится встречаться с сомнениями: так ли я вижу и понимаю? А это затрудняет выбор эмоционального фокуса в сессии.

Бывает, что на эмоционально заряженной ситуации в сессии связь прерывается или становится неустойчивой. Тут возникает любопытный момент. Обычно, если мы хотим работать и настроены на хорошую связь, то все так и происходит. В то же время, местами возникают различного рода помехи, которые могут быть в том числе отыгрыванием или реакцией переноса со стороны пациента, либо своего рода индикатором контрпереносных реакций терапевта. И речь не о паранормальных явлениях, а о том, как мы готовимся к сессии. Осознаем ли мы то, что происходит в терапевтическом процессе и с нами в том числе, что может мешать нормальной связи или не осознаем. Поскольку возможно, что по какой-то бессознательной причине мы не хотим видеть данного пациента или работать в этот день вообще.

Я думаю, что вы тоже сталкивались с ситуацией, когда во время сессии скайп просит его обновить и прерывается связь. Или компьютер начинает перезагружаться, или интернет отваливается по непонятным причинам. И снова вопрос: что за этим стоит и как обходиться с этим моментом? 
Когда пациент опаздывает или пропускает сессию, как правило, он ее полностью оплачивает. Должен ли он оплачивать, если произошли неполадки с техникой? У меня нет готового ответа на этот вопрос. При проблемах со скайпом я обычно пытаюсь связаться с пациентом какими-то альтернативными способами. Например, по телефону или в мессенджере. И в то же время, я чувствую себя растерянной. Я понимаю, что время идет, а связи нет и непонятно, кто за это несет ответственность. Это ситуация, в которой может возникнуть чувство вины. И хорошо, если мы его у себя заметим и проанализируем сами или с помощью супервизора.

Как написал кто-то из коллег вчера в чате: «Технические сбои - это прекрасная возможность еще раз встретиться и понаблюдать за своим бессознательным».

Если в отношениях с пациентом у нас хороший терапевтический альянс, то решить подобного рода вопросы довольно легко. Если же отношения напряженные, что случается на определенных этапах работы, или альянс еще некрепок, то такие ситуации вызывают дополнительные сложности и увеличивают паранойяльный компонент, который приводит к фантазиям, что что-то не ладится в терапевтических отношениях. Остается только надеяться, что со временем технологии станут лучше, количество технических проблем станет меньше, и работать тогда нам станет чуть полегче.

Когда мы работаем в кабинете, то готовимся к началу приема и соответственно выглядим, даже если рабочее место находится у нас дома. При онлайн варианте, когда пациент физически не находится в одном с нами пространстве, вполне может наступить некое расслабление по поводу тех частей нашего тела или пространства вокруг нас, которые обычно не видны на экране. И здесь нужно быть особенно внимательным и помнить о своем внешнем виде. Лично я несколько раз была невольным свидетелем того, как забывшись, мои пациенты поднимались, и оказывалось, что они сидели в рубахе и без штанов. 
То же самое касается и обстановки, в которой мы работаем. Приходится заранее продумывать, чтобы в объектив камеры не попали детали, которые не предназначены для глаз пациента - какие-то личные вещи, фотографии, отражение в зеркалах. Начинает иметь значение тот фон, который находится у нас за спиной. Необходимо задумываться об освещении, которое может быть неподходящим для онлайн-работы, в силу того, что монитор стоит так, как стоит. Независимо от времени суток, лично мне приходится включать дополнительный свет во время встреч с пациентами, поскольку у меня в кабинете за спиной находится окно, на фоне которого в скайпе виден лишь контур моего лица. Хотя при очных встречах это было не нужно. Я также прошу своих пациентов организовать для работы подходящее освещение, чтобы я могла их видеть.

Здесь добавляются и вступают в игру еще несколько факторов - это расстояние до экрана и наш возраст. Я думаю, что вы согласитесь со мной, что любому из нас хочется выглядеть хорошо (особенно прекрасной половине). И обычно наши пациенты не видят нас так близко. Я уже не говорю о том, что изображение на экране можно увеличивать и рассматривать малейшие детали. Лично я, когда писала доклад и подумала об этом, отследила беспокойство: а что, если кто-то из них действительно так делает, а я об этом даже не задумывалась раньше?

Хотя есть и другая сложность. Мы видим себя на своем экране в маленьком окошке и это существенно отличается от того, как нас видят наши пациенты. Лицо терапевта во весь экран может затруднять некоторым из них зрительный контакт, когда мы работаем лицом к лицу. А терапевту приходится постоянно помнить, особенно в эмоциональные моменты, когда важна мимика, что камера может искажать изображение в зависимости от того, как она расположена по отношению к лицу пациента. Также существуют оптические феномены, связанные с использованием линзы, когда на экране меняется 
левая и правая сторона. И тогда может возникать путаница и недоумение, а куда же и на что смотрит наш визави?

Я думаю, что стоит оговаривать эти технические моменты с пациентом в самом начале и пояснять, почему необходимо сделать именно так. Поправить или добавить освещение, отрегулировать расположение камеры и компьютера, поменять позу и т.д. Если заблаговременно позаботиться об обустройстве условий для работы, то снижается необходимость постоянно держать в своей голове все эти дополнительные детали, что, в свою очередь способствует уменьшению напряжения.

Когда мы работаем онлайн, то можем наблюдать ту часть жизни наших пациентов, которая при работе в кабинете нам недоступна. Ведь в кабинет пациент приносит только то, что он хочет, чтобы мы видели. В скайпе нам становится доступна какая-то часть их приватной жизни. Мы видим обстановку, в которой они живут. Иногда они хотят показать нам что-то важное для них в их доме, в их обжитом пространстве. Одна из моих пациенток даже провела для меня нечто типа экскурсии по всему уголкам своей квартиры, отмечая, какие из мест ей нравятся больше всего, а что она хотела бы изменить и улучшить. И тогда возникает ряд вопросов: кто я для нее? Я все еще ее терапевт или уже стала кем-то большим? Какая роль отведена мне в ее жизни? Что она таким образом мне хочет сказать? Что за этап наступает или уже наступил в наших с ней отношениях?

Как я, так и мои коллеги обратили внимание на то, что некоторые пациенты при переходе в онлайн формат работы начали легче говорить о вещах, которые были ранее загружены у них стыдом и практически недоступны обсуждению. Темы обозначались во время очных сессий, но погрузиться и проработать их было нереально. Возможно, что при дистанционной работе сопротивление уменьшается, когда дело касается стыда. И тогда возникает вопрос: эти изменения позитивны или негативны? 
Похоже, что при онлайн-терапии тревога снижается, что создает иллюзию близости. В скайпе пациентам часто легче говорить о тяжелых вещах и переживаниях. Возможно, что дистанционный формат терапии работает на защиту от стыда и тревоги, которая связана с близостью. Я думаю, что это не хуже и не лучше - просто онлайн-терапия действует и работает иначе. Это достаточно хороший инструмент, в чем я убедилась лично на себе. И в то же время, необходимо помнить, что он не всегда бывает уместен. И им нужно уметь (или научиться) пользоваться.

Когда мы встречаемся с глубокими проблемами личности и пациент начинает сразу же говорить о тяжелых событиях и переживаниях, я думаю, что не стоит применять раскрывающую терапию, особенно на начальных этапах. И это то ограничение, которое лично я учитываю при работе онлайн. В то же время дистанционная работа достаточно хороша в случае необходимости использования суппортивной терапии.

Виртуальное пространство позволяет легко отреагировать деструктивное поведение. Нажав кнопку, пациент прерывает общение и выходит из скайпа мгновенно, в отличие от ухода из нашего кабинета, который занимает некоторое время. Ведь обычно при прощании мы говорим уходящему пациенту несколько фраз. Я не раз с удивлением слышала, как эти фразы мне возвращали с комментариями, что именно они оказали большое влияние на то, что произошло впоследствии в терапии. Пациенты помнили не то, что происходило во время сессии, а то, что они услышали уже за пределами кабинета. Похоже, что наши слова при прощании являются в том числе тем самым «мостиком», который позволяет нашим визави остаться в кабинете, когда сессия уже закончена, и укрепляют связь. Увы, эта задача невыполнима при дистанционной работе.

Кроме всего прочего, время от времени в сети появляются сообщения о вскрытых переписках, взломанных сайтах и 
похищенных данных. И тогда неминуемо возникает вопрос о конфиденциальности - одном из основных и необходимых условий проведения психотерапии и анализа. Сможем ли мы гарантировать безопасность и неразглашение того, что происходит на сессии нашим пациентам? А если нет, то что? Как это отразится на наших пациентах и нашей практике?

Использование онлайн-терапии поставило перед нами много вопросов как профессионального, так и технического толка, на которые мы до сих пор все еще ищем ответы. Работа в скайпе привнесла в нашу профессию дополнительные задачи, которые необходимо решать. В нашем профессиональном сообществе до сих пор ведутся дискуссии на тему: должна ли быть разница в оплате за онлайн и очные встречи. Необходимо ли сочетать сессии в скайпе и вживую или придерживаться только одного вида работы с пациентом. Как решать вопросы с оплатой, если пациент живет в другой стране и это неминуемо вызывает сложности в данном аспекте работы.

Терапия онлайн - это работа, такая же, как и прием в кабинете. В то же время критерии ее размыты и временами совершенно непонятны. Научные данные противоречивы. Кто-то говорит о затруднениях, а кто-то - о достижениях. И окончательный ответ по поводу эффективности терапии онлайн на сегодняшний день отсутствует.

Ясно только одно. Мир изменился. И нам необходимо адаптироваться и найти для себя и наших пациентов наиболее подходящие способы для того, чтобы наша работа была достаточно эффективной.

\section{Литература:}

1. Buzsáki, G., \& Moser, E. I. (2013). Memory, navigation and theta rhythm in the hippocampal-entorhinal system. Nature neuroscience, 16(2), 130-138.

2. Gilman, N. V. (2015). Analysis for science librarians of the 2014 nobel prize in physiology or medicine: The life and work of John O'Keefe, Edvard Moser, and May-Britt Moser. Science \& Technology Libraries, 34(1), 1-18. 
DOI

\section{Валерий Дорожкин}

Доктор психологических наук, профессор кафедры психологии Института подготовки кадров государственной службы занятости Украины (Киев),

преподаватель Института последипломного образования

КНУ им. Т.Г. Шевченка, сертифицированный лидер балинтовских групп, член Дивизиона «Психоаналитическая психология и психотерапия»

ГС «Национальная психологическая ассоциация»

https://orcid.org/0000-0001-7755-1343

\section{ПОДРАМНИК И ПОЛОТНО ПСИХОАНАЛИТИЧЕСКОЙ РАБОТЫ ОНЛАЙН}

Когда я думаю, чем отличается онлайн психотерапевтическая работа от оффлайн, то самое главное отличие для меня в том, что появляется третий участник процесса. И этот участник проявляет себя не только в качестве Субъекта, но и Господина.

Он может позволять или не позволять что-то делать, он режет тела терапевта и клиента, оставляет от них только куски: в основном голову и плечи, но еще руки или фрагменты туловища.

Этот третий Субъект может прерваться и прервать сессию. И это не зависит от желания или нежелания двух других участников терапевтического процесса: аналитика и клиента. Третий Субъект создает специфические условия, выступает таким вместилищем, которое обладает целым рядом новых свойств.

Так, он в состоянии соединять несоединимое.

Например, вполне способен законнектить комнату и салон машины, залу в заснеженном Киеве и солнечный пляж в СанДиего, полдень долготы нашего часового пояса и сумерки в Австралии или Сингапуре; или, наоборот, сумрачный вечер в Киеве, когда мы пьем чай, кутаем ноги в плед и утро в ЛосАнжелесе, где солнечные блики пляшут в стакане воды. 
Топос третьего Субъекта особенный. Временной параметр здесь доминирует над пространственным. Нам нужно всего 5 секунд, чтобы со всем своим кабинетом переместиться к клиенту в любую точку Земного шара, и у нас есть 50 минут или час, чтобы с ним пообщаться.

Но, самое главное, мы зависим от этого Субъекта. Мы как терапевтическая пара или группа - платим ему деньги (за $\mathrm{Wi}-\mathrm{Fi}$, интернет или платные сервисы). И мы, я уже имею ввиду, нас - психотерапевтов, делимся с этим третьим субъектом властью, влиянием, разделяем с ним конфиденциальность, надеемся на его надежность в сохранении рамки сеттинга (на которую он, безусловно, также влияет), перекладываем на него ответственность в случае отдельных нарушений этой рамки и обвиняем, когда этот третий неожиданно начинает перезагружаться, или «пропадает связь».

У этого третьего Субъекта много имен.

Мы говорим Skype, Zoom, Telegram, Messenger, Signal, WhatsApp, Viber или WeChat. Есть и другие названия. Огромное количество именований, и все они ненастоящие. А настоящее его имя нельзя произносить. Потому что это имя раскрывает суть Господина - Большого другого в лакановском смысле этого понятия.

Так вот: суть его в том, что этот третий не просто выступает в отдельной позиции по отношению к нам - участникам процесса, но именно он выделяет места для наших позиций в своем поле. И потому его пространство является не только топосом, но, в некотором смысле, лоном. А почему лоном? А потому что, только лоно способно исторгать.

Мы говорим.

«Я сейчас в Skype». Безусловно, не я, но мое внимание, умения, контрпереносные реакции, чувства, ментализация, эмпатия, рефлексия и, в некотором смысле, даже часть моего тела. «Я уже зашел в Skype». 
«А меня только что выкинуло из Skype».

«Попробуйте выйти и зайти в Messenger снова».

«Сейчас открою вам Zoom-кабинет».

«Создайте, пожалуйста, еще одну комнату».

«Связь разорвало, и меня выбросило».

Во всех этих фразах речь идет о вместилище, которое то принимает нас и удерживает, а то принудительно исторгает. Наша традиционная реальность не создает нам такой опыт в повседневности. Но один раз он у нас уже был.

Иногда кажется, что возможности очередного коммуникатора - это и наши возможности, и их можно присвоить. Но это не совсем так. Достаточно вспомнить тот стресс и фрустрацию, которые мы испытываем, когда нас «выкидывает» из соединения. И мы сразу в этом убедимся.

Мы говорим:

«Меня Skyре не пускает».

«Telegram не позволяет мне».

«WhatsApp не дает».

И, в тоже время, мы помним слова М.Хайдеггера о том, что язык - это дом Бытия.

Я хорошо понимаю, в связи с чем ряд терапевтов не хотят работать онлайн. Ведь онлайн не только приходиться делиться властью, но и становиться зависимым. Зависимым от третьего, который еще и проявлен в отношении нас своей родительской функцией: пускает или не пускает; позволяет или не позволяет; дает или не дает.

Да и встреча с родительской функцией происходит не на нашей территории, и даже не на нейтральной полосе. Мы находимся в топосе третьего Субъекта. И играем по его правилам.

Таким правилам, где время важнее пространства, где соединены кабинет терапевта и территория клиента. Где наша власть утрачивает свою силу, без его гарантий, и где присутствует 
третий, который самим своим наличием обеспечивает возможность нашей терапевтической коммуникации. И хоть клиент попадает в наше пространство, но и мы оказываемся у него в гостях, в том мире и условиях, где клиент обитает. И мы уже не можем игнорировать реальную среду клиентского мира. И в этом тоже состоит отличие онлайн психотерапии.

Онлайн анализ - это специфическая игра. В этой игре мы всегда под надзором. Даже тогда, когда мы про это забываем или не чувствуем.

Раньше мы говорили:

«У стен есть уши». Еще перед этим: «У стен есть глаза».

А есть ли уши и глаза у онлайн-кабинета? Вопрос риторический.

Я не имею намерения индуцировать паранойю, но я говорю про надзор со стороны Большого Другого. Про его присутствие в качестве третьего, когда мы, хоть и остаемся для него анонимными, но становимся содержанием Big Data.

И я хорошо понимаю, в связи с чем ряд терапевтов не хотят работать онлайн. Им претит делиться властью с новым Господином нашего времени; и они не соглашаются быть на фоне или в присутствии третьего - того, кого не приглашали, но без которого невозможен процесс онлайн-терапии.

И если Messenger - это, в переводе с английского, «посланник» или «вестник», то самим именем он подает нам сигнал, что слово терапевта дано на его территории, а, следовательно, гарантии этого слова ограничены его волей. Или того, кто стоит за ним.

Наконец, вернусь к названию сообщения, к подрамнику. Подрамник - это то, что скрыто, но именно на него натянут холст. Может казаться, что в онлайн-анализе каркасом выступают все Субъекты. Но, с бОльшей вероятностью, каркасом является только один из них, а другие - терапевт и клиент лишь игроки на предоставляемом в аренду игровом поле. 
И, что самое поразительное, терапевт и клиент играют на этом поле не только друг с другом, но, в другое время, с целым рядом иных людей - друзей, родственников, знакомых, которые удалены от нас, и для общения с которыми также необходимы Skype, Zoom, Telegram, Messenger, Signal, WhatsApp, Viber или WeChat. А это означает, что пространство третьего Субъекта перенагружено ассоциациями из других сфер отношений.

И в заключении скажу, что для меня онлайн психотерапия более экзистенциальна. Экзистенциальна потому, что она обостряет вопрошание о самой реальности онлайн отношений. И хотя я помню, что коммуникация в терапии во многом задана переизданием раннего и повторением, но теперь сама возможность душевной близости подвешивается в качестве вопроса. И этот вопрос с новой силой ставит под сомнение понятие реальности. 
DOI

\section{Ольга Павловская}

Клинический психолог, сертифицированный психоаналитик, тренинговый аналитик ЕКПП, супервизор УАП, переводчик, преподаватель клинического психоанализа не-невротических пациентов, член Дивизиона “Психоаналитическая психология и психотерапия" Национальной психологической ассоциации Украины. https://orcid.org/0000-0002-9805-9400

\section{ОСОБЕННОСТИ ДИНАМИКИ ПРИСУТСТВИЯ И ОТСУТСТВИЯ ПРИ ПСИХОАНАЛИТИЧЕСКОЙ РАБОТЕ ОНЛАЙН}

В психоанализе понятия присутствие/отсутствие возращает нас к работе Фрейда “По сторону принципа удовольствия”, в которой в игре ребенка в присутствие/отсутствие (игра FortDa) Фрейд (1920) обнаружил аспекты зарождения процесса символизации: переход от действия к слову, проживание утраты и избывание аффекта от травмы потери объекта, и как результат, возможность трансформации реальности [11].

G. Kohon (2020) подчеркивает, что: «в аналитической ситуации для аналитика доступ к динамике присутствия/ отсутствия возможен благодаря работе негатива». Работа негатива емкое и многозначное психоаналитическое понятие, я бы хотела в своем докладе сконцентрироваться на узком, можно сказать, классическом фрейдовском значении негатива: данет; отсутствовать-присутствовать; видимый-невидимый; явный-сокрытый [9].

Я постараюсь в своих размышлениях о динамике присутствия/отсутствия проложить три маршрута, которые будут в докладе пересекаться:

- присутствие-отсутствие тел аналитика и анализанта на сеансе - речь о работе онлайн; 
- присутствие-отсутствие психического материала (ассоциации, сны, переносные чувства) с точки зрения слушания аналитика;

- особенности динамики присутствие-отсутствие при работе с не-невротическими пациентами.

Работа онлайн, уже ставшая нашей реальностью, актуализирует различные фантазии и переживания, которые могут стать распознаваемы аналитиком в связи с изменением в условиях работы, условиях сеттинга. Отношения аналитика и анализанта изначально многоуровневые, несомненно, что психоанализ отводит первостепенное место речи, но при работе онлайн можно попытаться понять как меняется вид диалога, совершает ли анализант движение вовне к Другому, дает ли аналитику возможность совершить движение внутрь. При работе онлайн аналитик и анализант используют главный канал для творения и общения - голос. Так как при работе онлайн отсутствуют тела, то именно голос, обеспечивает главное присутствие.

Отсутствие тела порождает парадоксальную ситуацию избыточного присутствия голоса. Французский психоаналитик Г. Розолато (1974), большой любитель оперы, написал работу «Голос: между телом и языком», касающуюся роли голоса в формировании телесного Я - его роли как «акустического зеркала», находящегося на полпути между телом и языком. Он рассматривал материнский голос как звуковую оболочку Я, начиная с утробы матери, обволакивающую Я ребенка [4]. Акустическое зеркало является частью сонорного телесного зеркала, описанного Д. Анзье (1994) как нечто функционирующее между матерью и ребенком, одновременно объединяя и разъединяя их. Голос задействует одновременно мысль и тело [6].

Одна из функций голоса, наряду с другими частичными объектами влечений: взглядом, мышцами руки и т.д. - дотянуться до Другого. То есть, с помощью использования голоса 
как вспомогательного объекта, расположенного в недрах тела можно достичь Другого, дотянуться до объектов вне себя и своего тела [7]. Такое движение указывает на переход влечения в объект и на возможность поддержания значимой инвестиции объектов [9].

Британский публицист и культуролог S. Connor (2004) подчеркивает: «для младенцев голос - это первое схватывание, способ извлекать и переносить объекты желания, когда другого пути для этого просто не существует; ребенок в кроватке передает сообщения в мир с помощью голоса. Ребенок, который научился координировать взгляд и руку для захвата и переноса предметов, видимо помнит, что голос может достигать большего, чем кулак или пальцы» [1].

Автор идентифицирует голос в основном как расширение способов дотянуться до другого, как способ притягивать то, до чего физически невозможно дотянуться. Он сравнивает голос с телефонным проводом, который тянется и возвращается назад, как язык лягушки. Он отмечает, что в латинских языках коннотация слова «языки»: удлинение. Мы действительно в речи поддерживаем это, говоря: «Оставайся на связи», «Я потерял нить разговора». Можно сравнить издание звуков (пение, плач, крик, напряженное кряканье, вздыхание, покашливание и т.д.) - с забрасыванием петли лассо, удочки рыболова в сторону Другого [1].

Важно, что все эти стремления выйти за пределы тела должны быть распознаны и поддержаны Другим. Тогда ребенок получит опыт трансформации реальности. Альтернативой стремления достичь Другого с помощью вспомогательных объектов становится отказ от связи с Другим.

Мой клинический опыт онлайн работы с анализанткой с врожденной патологией слуха, убеждает меня в важности поддерживать анализантку в ее способности дотягиваться до Другого. Врожденная патология слуха, изменила нарциссическое 
инвестирование ею собственного тела и его потенциальных возможностей, что повлияло на ее фантазийную жизнь, в которой привилигированным объектом стал взгляд, избыточность которого вызывает у нее параноидную тревогу.

M. Dos Santos (2017), анализируя связь музыки и психоанализа, указала на параллели между психоанализом и шаманизмом, подчеркивая, что сексуализация, пронизывающая ритуалы; дуализм влечения к жизни и смерти, символическая игра, переходность процессов; агрессия и деструкция - роднят эти практики. Психоанализ находится в динамическом поле, постоянно находящимся в движении, связанном с человеческой природой: это игра на границе прошлого-будущего, внутреннего-внешнего, присутствия-отсутствия [5].

Клинические описания.

Хотела бы привести два примера из клинической практики, когда внешнее событие: переход в онлайн вызвало различные эффекты.

\section{Первый случай: мужчина, 38 лет}

Всем своим внешним видом, двигательной активностью, скоростью мышления анализант демонстрирует некое избыточное присутствие в своем теле, которое он с помощью движений пытается изжить. У него большое количество видов занятий: бизнес, спорт, танцы, быт. Отдыха он почти не знает, заполняя себя бесконечными мыслями. Становится очевидным, что в его истории объектами посредниками между ним и Другим стали анальный объект, и его заменители деньги, манипулируя которыми, он практически гарантировано дотягивается до Другого. Особым смыслом наделены движения рук и заменители этого телесного органа, позволяющие ему осуществлять захват и удерживание в коммуникации с другими. Но и кастрационная тревога у него касается физического страха сломать руку, и, метафорически, «опустить руки» в смысле сдаться. Можно сказать, что в его психической реальности эти 
объекты и их метанимические заменители являются привилегированными объектами, задающими вектор психического инвестирования. Своего отца анализант описывает как жестокого и импульсивного, а мать непоследовательной и достаточно беспомощной женщиной. Когда аналитик предложила анализанту продолжить работу онлайн в связи с локдауном, анализант отказался, говоря, что он будет ждать очных встреч. После окончания локдауна, он продолжил работу.

\section{Второй случай, молодой парень, 27 лет}

Единственный сын, неуверенной в себе, депрессивной матери, которую оставил муж и нарциссического захватывающего всеобщее внимание отца. Внешний вид анализанта производит парадоксальное впечатление: присутствует заметная робость движений, смущение во взгляде, что производит впечатление общей телесной вялости, но при этом у анализанта тренированное тело. Его запрос очень поверхностен, касается желания, чтобы у него было то, что есть у других. Он обнаруживает слабый интерес к своей внутренней жизни, и в реальности много скучает, не знает как достичь целей и бывает буквально парализован ситуациями выбора. Такая позиция в переносе периодически сменяется поисками с его стороны особого места в терапии. Из личной истории стало понятно, что перед его рождением у матери были две неудачные беременности.

В ответ на предложение психоаналитика во время локдауна перейти к онлайн встречам, он соглашается, но после нескольких встреч отказывается и прерывает работу.

Коротко, хотела бы провести различия между этими двумя случаями. В обоих случаях мы сталкиваемся в неудачей инвестирования Я нарциссическим либидо.

В первом случае, анализант смог психически и телесно инвестировать свой нарциссический образ, миметическая функция которого позволяет ему учитывать Другого. Проводя различия между собой и другими, он настаивает на своих 
локальных признаках, отличающих его от образа родителей. Неудачу он потерпел на этапе попытки выразить себя, и в рамках совместного переходного пространства представить другим свой образ: страх кастрации, исходящий от слишком грозного отца, заставляет его выходить за пределы тела в поисках удовольствий, а значит двигаться от ауэтоэротического удовольствия к внешним объектам реальности, но при этом, при разрушении совместного переходного пространства он испытывает тревогу, однако, способен восстанавливать его, тем самым удерживая связь с Другим. На мой взгляд, это возможно, благодаря его способности нарциссически инвестировать объекты, тем самым расширяя возможности для движения либидо. Предположу, что онлайн встречи с психоаналитиком на текущем этапе работы столкнули бы его с затруднением дотягиваться до Другого с помощью его привилегированных объектов и их заменителей: анальный объект и руки. Но при этом избыточное присутствие объектов влечений голос и взгляд, обеспечивающие главное присутствие при работе онлайн, столкнули бы его с избытком возбуждения и отсутствием психических инструментов изживания и трансформации этого возбуждения. Поэтому, прерывание дало ему возможность избежать слишком возбуждающей ситуации, при этом сохранив инвестирование и процесса, и аналитика.

Во втором случае, анализант потерпел неудачу в построении нарциссического образа, он буквально является оттиском, отпечатком образов своих родителей, плохо разделяя себя и их, его тревоги сосредоточены в страхе потери нарциссического объекта - который он достаточно слабо инвестирует. В этом случае преобладает отказ от связи с Другим. Анализант не столько защищается от избыточного вторжения Другого, как сталкивается с пустотой утраты в случае работы онлайн, так как это пространство для него становится радикально иным, неузнаваемым, чуждым. Поэтому, при изменении режима работы 
он быстро теряет интерес, возвращая свое нарциссическое либидо на ранее занятые позиции в виде родительских образов.

\section{Гипотезы}

Как мы могли бы распознать, узнать, расслышать влияние этого события - перехода в онлайн - на ассоциативные движения на сеансе, на характер инвестирования анализантом сессии? Ответ: через то, какой психический материал отсутствует или присутствует на сеансе или какое движение вовне или внутрь является первостепенным.

Рассмотрим ситуацию при работе онлайн, когда анализант жалуется на кого-то в жизни или на аналитика, жалоба может быть и на усталость и т.д. Являются ли эти жалобы жалобой на покинутость, скорбью, видом погребального ритуала как в случае истерической жалобы, прикрывающей в конце концов разочарование в матере-аналитике? В жизни ребенок разворачивает причитания, жалобы, плач, нытье тогда, когда в семейной системе есть запрет на выражение страдания от покинутости. Мы должны задуматься не является ли такая ситуация ситуацией зеркального переноса при котором анализант как эхо матери вторит страданию аналитика, который свое страдание и утрату не признает. Возвращаясь к динамике присутствия - отсутствия: в описанном случае анализант присутствует на сеансе как эхо аналитика, но отсутствует как субъект своего собственного желания, он не может иначе появиться и вынужден быть эхом матери. Должен быть кто-то, кто это страдание - быть эхом другого - прекратит, иначе анализант оказывается на сеансе в ситуации человека, который звонит сам себе. [5]

Предположу, что работа онлайн может проявить подобную связь между анализантом и аналитиком, благодаря избыточному присутствию голоса как главного канала общения. Метафорически, эта ситуация указывает на трудность анализанта дотянуться до Другого, на трудность выйти за пределы своего тела и Я, и тем самым, остановив страдание, трансформировать реальность. 
Восприимчивость к смене режима работы более свойственна не-невротическим анализантам, ведь их трудности связаны и с интрапсихическим измерением и с интерсубъективным. Невроз - это конфликт в интрапсихическом измерении. Не-невротики же сражаются сразу на двух фронтах: и с импульсами влечений, и с импульсами, исходящими от Другого. Как говорил Винникотт (1971), «психотическая мать, не то же самое, что достаточно хорошая мать» [8]. Это проявляется в переносе. Поэтому, любое избыточное присутствие (например, голоса) в аналитической ситуации будет влиять на характер инвестирования сессии и фигуры аналитика. Речь о таких видах инвестирования как нарциссическое и объектное.

Нарциссическое инвестирование всегда проходит по двум осям: инвестируется Я и инвестируется - не Я. У неневротиков развитие нарциссизма потерпело неудачу, но нарциссизм является защитной конструкцией, именно формирование нарциссического образа дает возможность отказаться от деструктивности. Примером неудачи формирования нарциссизма являются психосоматические пациенты, их внутренняя деструктивность против своего тела говорит о том, что «раненый нарциссизм» не стал бастионом сопротивления деструктивности [2].

На мой взгляд, при онлайн работе с не-невротическими пациентами:

1. важно обратить внимание на то, какой способ инвестирования образа себя выбирает анализант в ответ на отсутствие тела аналитика и соответственно избыточное присутствие голоса:

- инвестирование Я (нарциссическое либидо захватывает Я);

- инвестирование не-Я (нарциссическое либидо захватывает не-Я);

- отказ от нарциссического инвестирования объектов (отказ от нарциссического захвата - тогда открывается дорога к деструктивности) 
Напомню, что против избыточного присутствия голоса аналитика может развернуться работа негатива.

2. важно исследовать вместе с анализантом его способность трансформировать реальность.

G. Kohon (2017) пишет, что «согласование между Я - не Я, между тем, кто ты есть и его отрицанием лежит в сердцевине субъективности. Я хочу быть подобен самому себе и распознавать, где есть не Я. Стадия зеркала предлагает возможности для полной идентификации, открывая доступ к первичному нарциссизму. Одновременно рождается двойной субъект и Я и не-Я, формируется измерение подобный мне и не подобный. У нас, действительно, нет истинных границ между Я- не Я, есть лишь смутная переходная зона и есть спектр идентификаций, определяющий различные позиции, которые захватываются нашим нарциссическим либидо» [2].

В аналитической ситуации психоаналитик и является переходным объектом для анализанта, психоаналитик объект с помощью которого, он трансформирует реальность. Винникотт (1971) писал о переходном пространстве как пространстве перехода от аутоэротизма к внешней реальности [8].

Важно, что утрачивая совместное переходное пространство или, если оно подвергается значительным изменениям (речь о работе онлайн) - субъект, чтобы удержаться, выходит за пределы этого пространства, пытаясь вводить новые объекты, (они все нарциссически инвестированы) с помощью которых он может трансформировать реальность. Следовательно, можно сделать вывод, что в работе с не-невротическими субъектами, эффект при переходе в онлайн может проявиться в усилении нарциссического инвестирования внешних объектов, как подобных, так и не подобных, можно сказать, что в переходном аналитическом пространстве случается землетрясение и восстановление разрушенного. Это возможно в случае, если голос как основной канал общения в работе онлайн стал объектом 
с помощью которого возможно достичь Другого. Если с помощью голоса не удалось достичь Другого и удержаться, то переход в онлайн приводит к утрате и так слабого нарциссического захвата аналитика и прерыванию анализа. Через отсутствие, через выпадение из реальности происходит превращение влечения из пассивной формы в активную на уровне действия бросания, но влечение не инвестирует нарциссическим либидо образ самого себя. Это частный случай работы негатива.

После ужасов Первой и Второй мировых войн, после столкновения с избыточным присутствием в жизни зла, деструктивности и крушения смыслов, когда напряжение голоса более уже не приводило к изменению реальности, а превратилось в «акустическое зеркало», которое дублировало и множило ужасы, культура как переходное пространство столкнулась с катастрофой. В этот период появляется постмодернисткое художественное искусство, увлекающееся эстетикой небытия: создание форм пустоты, разрезов, превращения в ничто, тотальной деструкцией. Творческие люди работают над превращением образа бытия в образ небытия. Например, художники трансформируют абстрактную картину в объект с нарушенной поверхностью: холст режут, поджигают, перфорируют. Поверхность картины представляет из себя в этих случаях поле для насилия, разрушения [10].

G. Kohon исследуя связь между искусством и психоанализом подчеркивает, что эстетика - это чувственная восприимчивость. В этом смысле и в культуре, и в искусстве существует эстетика бытия и присутствия и эстетика небытия и отсутствия. Эстетика небытия включает в себя не только создание форм пустоты, но и создание форм и образов вторжения, для этого задействуются элементы окружающей среды [3].

Например, художник, после войны создает работы, оборачивая холст пропитанными кровью бинтами. То есть, акт творения связывается с деструктивным действием над поверхностью холста [12]. 
Есть переживания и впечатления, которые невозможно ухватить и выразить с помощью создания художественных образов. У. Бион, участвующий в сражениях Первой мировой войны, изучал формы выражающие действительность и исследовал механизмы ее выражения. Его идеи об а -и В элементах близки постмодернисткому дискурсу:

а-элементы - это чувственные впечатления и эмоциональные переживания, в которые преобразовались зрительные, слуховые, обонятельные или другие образы в психической сфере. Эти элементы задействуются при возникновении мыслей сновидения, при бессознательном размышлении в состоянии бодрствовании, в воспоминаниях;

В-элементы - это нетрансформированные чувственные впечатления и эмоциональные переживания. Они не годятся для размышления, сновидения, запоминания. Это «непереваренные» элементы, несимволизируемые переживания, сырой материал в психике, непригодный для психической переработки. [8]

Возвращаясь к не-невротическим субъектам, мы говорим о провале функции воображения. И это вопрос нарциссизма, себя следует вообразить и представить Другому, и, если захват Другого удался, то мы имеем дело с эстетикой бытия. Возможность создавать образы преобразовывает реальность в культуру, открывая дорогу переходу от аутоэротизма к внешней реальности.

Воображение обладает двумя способностями, которые использует искусство:

- изображать (воплощать в образы) - миметический, подражательный аспект искусства;

- выражать (воздействовать образами) - выразительный аспект искусства [10].

\section{Выводы}

Не-невротический субъект может столкнуться с субъективным провалом на этапе воображения своего нарциссического образа, и на этапе обнаружения выразительной силы своего образа. 
Если провал касается первого этапа, то переход работы в режим онлайн может повторить травму, так как для создания образа себя необходимо присутствие реального тела, вызывающего аффекты.

Если на втором этапе, то перевод аналитической работы в онлайн режим может прервать работу на время, но она может быть возобновлена, так как у субъекта присутствует способность удерживать и восстанавливать совместное переходное пространство за счет нарциссического инвестирования других внешних объектов.

\section{Литература:}

1. Connor, S. (2004). The strains of the voice. In Emotions in the Human Voice, Volume 3: Culture and Perception. Plural Publishing.

2. Kohon, G. (2017). Some thoughts on the negative in the works of Eduardo Chillida. In The greening of the psychoanalysis, Edited by R. Perelberg and G.Kohon, Karnac Books.

3. Kohon, G. (2015). Reflections on the aesthetic experience: Psychoanalysis and the uncanny. Routledge.

4. Rosolato, G. (1974). La voix: entre corps et langage. Revue Française de psychanalyse, 38, 75-94.

5. Dos Santos, M. (2017). Musique, mémoire et émotion: les lamentations, un objet de la psychanalyse et de l'art-thérapie? Cahiers d'ethnomusicologie. Issue 30, p. 91-106.

6. Анзьё, Д. (2011). Я-кожа. Ижевск: Ergo.

7. Анзье, Д. (2015). Мышление: от Я-кожи к Я-мыслящему, пер. с фр., под ред. С. Сироткиной, М. Мельниковой. Ижевск: ERGO.

8. Бион, У. (2008). Научение через опыт переживания. Москва. Когито-Центр.

8. Винникотт, Д. (2008). Игра и реальность. Москва: Институт гуманитарных исследований.

9. Грин, А. (2020). Работа негатива. Киев: изд. Ростислава Бурлаки.

10. Саенко, Н, Вальковский, А. (2011). Небытие и пустота в артпрактиках постмодернизма. Электронный ресурс artandyou.ru

11. Фрейд, 3. (2007). По ту сторону принципа удовольствия. В книге Психика: структура и функционирование. Пер. А. Боковиков. Москва, Академический Проект.

12. Искусство и техника: как работают образы? (2020). Электронный ресурс www. monocler.ru 
DOI

\section{Юлия Салий}

Психоаналитик ЕКПП, супервизор Одесского психоаналитического общества,

Руководитель Одесского психоаналитического института, член Дивизиона "Психоаналитическая психология и психотерапия" Национальной психологической ассоциации Украины https://orcid.org/0000-0003-0679-1248

\section{НАРЦИССИЧЕСКАЯ УЯЗВИМОСТЬ И ТЕРАПИЯ ОНЛАЙН}

Многолетний опыт пребывания в психоаналитической среде заставляет с грустью заметить, что, несмотря на отчаянные попытки мыслителей, начиная с Хайнца Кохута, развести понятия нормального и патологического (деструктивного, злокачественного) нарциссизма, даже у многих практикующих психоаналитиков представление о нарциссизме чаще соответствуют нарциссическому расстройству личности, чем другим клиническим синдромам, получившим обобщенное определение «нарциссически травмированная личность».

Растиражированное, как научной, так и не очень литературой, представление о надутом, высокомерном существе, лишенном эмпатии, завистливом, паразитирующем и эксплуатирующем других людей, отчаянно голодном по признанию и одновременно неспособном ни к какой любви стало причиной стигматизации и определенного страха определения «нарциссический» и пациентами, и, что намного хуже, психотерапевтами.

Вместе с тем, если нарцисс ядовитый, назовем его так, чрезвычайно редко появляется в кабинете терапевта, зато часто уходит по своей недоброй традиции избегать всего, что фрустрирует его защитное нарциссическое величие, пациентов с нарциссической уязвимостью, намного лучше настроенных на изменения, способных к благодарности и поэтому заслуживающих 
особого разговора о «скользких местах» психотерапии нарциссически травмированной личности довольно много, а сегодняшняя реальность плохо способствует стабилизации и много требует маневренности и поиска новых решений в терапии, как офлайн, так и онлайн.

Если вспомнить о том, что, по сути, весть пограничный уровень развития личности в той или иной мере демонстрирует признаки патологического нарциссизма как защиты хрупкого Я от чувства одиночества и никчемности, то становится понятно, что сегодняшняя ситуация пандемии, карантина, неопределенности, угрозы существованию и тревоги провоцирует общую регрессию психической структуры и усиление патологических защит.

В этом случае среди проблем психодиагностики и психотерапии на первый план выдвигается разговор о такой патологической защитной структуре, как ложное Я, и не менее патологической защите - диссоциации.

Парадоксальным образом, большая часть носителей тяжелых личностных расстройств в силу регрессии могут производить куда более стабильное впечатление в состоянии стресса и депривации, чем можно было бы ожидать. Псевдоневротизм ложного Я создает обманчивое впечатление, и, помноженный на театральность и склонность диссоциировать, - опасную ловушку для психотерапевта. Я бесконечно благодарна своей супервизантке за сообщение «Я работала с пациенткой как с невротиком до тех пор, пока она не начала приносить сновидения».

В случае терапии он-лайн очевидная депривация всех каналов восприятия, особо - телесная, порождает дополнительную реактуализацию травматической сепарации, что также усиливает патологические защиты и замутняет и без того неясную картину.

K сожалению, я сталкивалась с последствиями молчаливого сговора «примерного» ребенка и не в меру оптимистичного психотерапевта. Ничего хорошего из этого не выходит. 
Но, к счастью, этот опыт позволяет сделать определенные выводы и предвосхитить будущие ошибки.

Это важно, в первую очередь, потому, что работа с невротической и нарциссической структурой личности изначально предполагают принципиально разные стратегии взаимодействия.

Для меня определяющей является идея Хайнца Кохута, изложенная им в работе «Восстановление Самости»:

«Некоторые из наиболее стойких сопротивлений... возникают в ответ на то, что стадия понимания - стадия эмпатического эха аналитика или слияния с пациентом - была пропущена. В некоторых случаях анализа - хотя отнюдь не во всех аналитик даже не будет осознавать, что пациенту, чей объект самости в детстве травматическим образом разрушил его ожидания в этой области, потребуется длительный период «одного только» понимания, прежде чем можно будет с пользой приступить ко второму этапу - интерпретации, динамическим и генетическим объяснениям, даваемым аналитиком» («Восстановление самости»).

Добавлю также, что в моем понимании представление Кохута об «эмпатическом эхе аналитика» имеет много общего с представлением Уилфреда Биона о «контейнировании».

Моя личная терапевтическая судьба необратимо убедила меня в том, что, если пациент достаточно невротичен, избыточное слушание ему никак не повредит, если же он нарциссически травмирован, поспешные интерпретации навредят почти гарантированно. В плохом случае - это обрыв терапии, когда исправлять допущенные ошибки будет уже не с кем. Как супервизор, я часто притормаживаю и охолаживаю супервизантов, алкающих интерпретаций в порядке выполнения священного терапевтического долга. Наш главный долг - не навредить.

Если скорость терапии оценивать количеством интерпретаций, тогда терапия нарциссически травмированных людей - 
очень медленная терапия. В терапии он-лайн скорость падает почти до нуля.

Исходя из этого понимания, полагаю, будет полезным определить некоторые «маркеры», позволяющие предположить нарциссическую уязвимость при любых усыпляющих бдительность маневрах ложного Я.

Если говорить о первом и общем впечатлении, то, на мой взгляд, всегда следует обратить внимание на некоторую отстраненность или дистантность пациента. По наблюдению Хайнца Кохута, у нарциссически травмированных людей зачастую нарушен теплообмен, что является телесным выражением переживания депривации. Это может проявляться в не по погоде теплой одежде или непосредственном сообщении, что пациент «всегда мерзнет». Речь коррелирует с бессознательным, в силу чего странность нарциссически уязвимой личности зачастую и получает у окружающих определение «отмороженный» или грубее - «отморозок».

Алекситимия, закономерное следствие фрустрированной потребности в контейнировании, выдает себя тем, что повествование принимает характер «экшена», то есть описывает события как последовательность действий: «А он сказал... а она сказала... а я вскочил и выбежал, хлопнув дверью...». В этом случае эмпатическое эхо звучит более или менее как «Полагаю, Вы почувствовали страшную обиду, когда ваша девушка в споре встала на сторону вашего друга...». Если не удается вклиниться, что естественно, если учесть, что на пограничном уровне пиковые аффекты занимают намного больше места, чем у невротиков, я просто дожидаюсь окончания истории и «возвращаю ее пациенту, но уже как эмоциональночувственную картину произошедшего.

Для первоначального впечатления безусловно полезным является определение Мелани Кляйн тревог и забот параноидно-шизоидной и депрессивной позиций: тревога преследования 
и озабоченность собственной целостностью, с одной стороны, депрессивная тревога и озабоченность собственной разрушительностью - с другой. Соответственно, от пациента, пребывающего на параноидно-шизоидной позиции, при любом позиционировании невротических ценностей, мы будет слышать сообщения о каком-нибудь ущербе или разрушительном воздействии (физическом или психическом) со стороны другого или окружающих. В этом случае следует учесть наличие или отсутствие актуальной причины для общей регрессии (потерю работы, отношений и т.д.). Кляйн говорит о том, что депрессивная позиция никогда не достигается индивидом вполне, и в состоянии особого напряжения любой человек может вернуться на параноидно-шизоидную, что очень наблюдаемо в ситуации пандемии и карантина. Однако выраженность подобных переживаний, при любых подробностях, остается хорошим маркером пограничного уровня развития личности.

Из внешних признаков, которые бросаются в глаза еще до всякой картины жизни пациента, достаточно надежными маркерами пограничного уровня являются экзотический (в любом смысле) внешний вид и, особо, обширный пирсинг и татуировки. Последние, с учетом склонности пограничной личности к постоянным самоповреждающим действиям и измененного переживания физической боли, являются эстетизированным эквивалентом самоповреждения.

Кроме ложного Я, первобытных аффектов и тревоги преследования, нарциссическую структуру личности отличает также так называемый оральный гнев, то есть склонность реагировать агрессией на фрустрацию. Это может выглядеть как некоторая раздражительность или язвительность. Кернберг определяет раздражение как потенциал злобы.

Поскольку представление о нарциссической уязвимости связано, главным образом, с двумя переживаниями - состоянием брошенности (одиночества) и чувством никчемности 
(ненужности, малоценности), в истории пациента следует обратить особое внимание на: телесные недуги, лишения, травмы, ущерб, угрозу существованию, оперативные вмешательства (особенно на ранних этапах развития); утрату родителей; родительское отвержение пассивное или активное; использование родителем ребенка как «нарциссического расширения»; ротацию ролей в детско-родительских отношениях; массированные травмы отвержения и унижения (травля, буллинг, бойкот или другие формы игнорирования); длительное пребывание в культуре или субкультуре, ценностные ориентиры которой существенно отличаются от усвоенных в процессе развития.

«Я появляется как телесное» (Фрейд). На ранних этапах развития ребенок взаимодействует не столько с реальной матерью, сколько с материнским имаго, выстроенном проекциями собственных влечений (Кляйн). Если физическое неблагополучие обрекает ребенка на страдания, в этот момент он переживает «плохую мать», независимо от реальной заботы биологической матери. Преждевременное появление на свет становится фрустрирующим уже в силу незрелости организма. Обычные воздух, вода и свет раздражают, а ситуация кормления из удовольствия превращается в мучение. Материнское контейнирование осложняется невозможностью устранить физическую боль.

С другой стороны, агрессивные средовые влияния также отражаются на переживании телесного Я. Следует обратить особое внимание на сообщение о холоде (в роддоме или дома), точно так же, как на аналогичные сообщения на протяжении всего развития. По моему опыту, важное значение имеет климат, в котором человек родился и рос, или невнимание окружающих к тому, достаточно ли тепло ребенок одет. Нарушение теплообмена может выражаться и в очевидной нечувствительности к холоду. 
Ограниченные возможности и соматические заболевания, особенно сопровождающиеся физическими страданиями, неминуемо отражаются на характере. Боль физическая всегда и психическая - удар по первичному нарциссизму с его фантазиями бессмертия, неуязвимости и всемогущества. В этом случае мы говорим о соматопсихических искажениях.

Люди, потерявшие родителей, осознанно или бессознательно связывают уход родителя с собственной «плохостью». Иногда смерть родителей наносит самооценке не настолько сильный ущерб, как уход из семьи с последующим пренебрежением оставленным ребенком. Тем не менее, необходимо понимать, что представление о смерти как о небытии, плохо доступно человеческому воображению, уж подавно, воображению ребенка. Эвфемистические формулировки, наподобие «ушел в лучший мир», только усугубляют дело. Родители - это и есть мир ребенка, то есть лучший мир - это лучший по отношению к миру семьи, соответственно последний оказывается плохим или, по меньшей мере, недостаточно хорошим.

Наиболее труднодоступной для осознания является агрессия по отношению к умершим родителям, тем более, что ее подавление подпитывается культурой, а неприемлемость, да и нелогичность винить умерших за то, что они умерли, способствует меланхолическому оборачиванию упреков на себя (Фрейд, «Печаль и меланхолия»). Кроме чрезмерного чувства вины, проблем выражения агрессии, общего чувства ненадежности и нестабильности бытия, эти пациенты демонстрируют также неумение (неспособность) жаловаться, плакать, обвинять и часто обесценивание любых личных проблем, если они меньше, чем смерть.

Травматичность развода, безусловно, зависит от способности ушедшего родителя нести дальнейшую ответственность за оставленного ребенка и участвовать в его судьбе. То, что именно безответственность во всех отношениях и послужила 
причиной развода, понимает уже взрослый человек, пришедший на терапию. Точно так же, как взрослый человек может вполне понимать, что алкоголизм, наркомания, тяжелые личностные расстройства очень плохо лечатся, особенно, если больной больным себя не считает и лечиться не собирается. Это никак не отменяет страданий ребенка, жалобы которого было некому выслушать. И здесь же мы зачастую обнаруживаем ротацию ролей - ребенок был вынужден поддерживать и утешать оставшегося родителя.

Люди, которых родители отвергали пассивно (то есть старались любить ребенка, но не любили) или активно (родители делегировали напрямую малоценность - «Я рожала детей для того, чтобы было кому мыть полы», никчемность, уродство от экстремальных примеров я воздержусь, зная, что любой практикующий аналитик может подбросить свои) демонстрируют особую готовность к чувству отвержения. В трагических случаях создается впечатление, что ребенка рожали, чтобы было, над кем издеваться, что также может выливаться в выраженные мазохистские тенденции как способа адаптации к патологической среде развития.

Здесь я хочу вернуться к разговору о терапевтической позиции.

Как-то за столом одна моя подруга, тоже психотерапевт, спросила меня: «Что ты делаешь, если пациент задерживает оплату?». Я ей ответила: «Запоминаю». Этот ответ я дала бы на очень многие вопросы, возникающие в связи с психотерапией, особенно на начальных ее этапах.

В психоанализе существует представление об интерпретациях неправильных и несвоевременных. По этому поводу я мрачно шучу, что несвоевременные интерпретации существуют только в разговоре с супервизором. Для пациента несвоевременная интерпретация ничем не отличается от неправильной. 
Я объясню это на примере следующей группы нарциссически травмированных людей - тех, которые были нарциссическим расширением своих родителей.

Психоаналитическое представление о нарциссическом расширении также связано с понятием эмпатии (особое место оно занимает в Психологии Самости Х.Кохута) или точнее отсутствием таковой со стороны родителей в направлении ребенка. Это ситуация, когда ребенок является вместилищем родительских желаний, целей, амбиций и т.п. По отношению к чувствам и желаниям самого ребенка родитель демонстрирует равнодушие, игнорирование или нетерпимость разной степени выраженности. По моему опыту, именно такое отношение порождает сновидения, когда сновидец кричит, но понимает, что его не слышат (как вариант - не видят, смотрят сквозь) или еще возможно - пытается закричать, но вместо крика выходит какой-то слабый звук (по выражению одной пациентки «как тянущаяся пленка»).

Чувство несуществования, свойственное многим нарциссически травмированным людям, - производное от их несуществования ребенка в глазах родителя как «центра самостоятельного чувства- и волеизъявления» (выражение Х. Кохута).

Такая травма, помимо прочего, плохо сознается как травма, поскольку нарциссический родитель зачастую уделял ребенку много времени, внимания и сил. И понять, что одновременно тебя полностью игнорировали - затруднительно. Одно из определений нарциссизма - травма тем, чего не было любви, уважения, эмпатии.

Депрессия и агрессия за несуществование копится годами, как я уже сказала, плохо поддается осознанию, но пребывает в состоянии аффективной готовности.

В этой ситуации преждевременная интерпретация превращается в очередное навязывание со стороны родительской фигуры чего-то, чего я сам не думаю, не чувствую и не хочу. 
Хорошо будет, если реакцией последует ярость. Хуже, если довербальная депрессия. Еще хуже, если на авансцену привычно выйдет ложное Я. Ну, и край - ложное Я вежливо прощается, уже в дверях или смской сообщает о делах безотложной важности, мешающих в данный момент продолжить анализ, обещает написать при малейшей возможности, благодарит за проделанную работу и исчезает навсегда, ибо с детства сыто по горло людьми, благодаря которым оно и отросло.

Эмпатическое эхо (или контейнирование) наоборот позволяют постепенно материализоваться пациенту не в плане тела, но в плане чувств. Важно только, чтобы ваше понимание соответствовало истинному положению вещей. Кривое зеркало ничуть не лучше преждевременной интерпретации.

Все эти усилия я прилагаю лишь для того, чтобы вернуть человеку его самого. Сколько на это уходит? Годы. Нет, конечно, я не имею в виду, что работа с нарциссически травмированными людьми начисто лишена интерпретаций, работы с сопротивлением, работы с переносом и других бесценных наработок психоанализа. Но в моей практике они занимают несоизмеримо меньшее место, чем это принято в академической традиции.

Справедливости ради нужно сказать, что и в этом случае обрывов не избежать. Но обрыв обрыву рознь. Тот же Кохут призывает больше доверять пациенту в его желании уйти, потому что такой уход может быть интуитивным пониманием, что сейчас он не выдержит дальнейшего погружения.

Иногда люди также уходят, потому что хотят сохранить идеализированный объект. Как показывает опыт, они возвращаются спустя месяцы или годы, и ты никогда не знаешь, вернутся ли вообще. Но, как врач скорой помощи, я всегда на связи.

Я отлично знаю, что перенос сессии может быть выражением сопротивления и, тем не менее, переношу их по просьбе 
пациента, если есть такая возможность. Для меня единственный ориентир - могу ли я найти другое время без ущерба для собственной личности, проявить терпение без мазохизма. Что характерно, в случае отказа, люди с выраженной фрустрационной готовностью демонстрируют устойчивость и доверие, построенные на опыте честного отношения к ним.

Так же я отношусь к «внеурочным» сессиям или к сессиям с очевидными помехами для общения. В моей практике был случай, когда за одну сессию связь оборвалась никак не меньше двух десятков раз (пациент был далеко в отъезде), но мы соединялись снова и снова, и снова, и снова. Нечего и думать, что в таких условиях можно услышать или сказать что-нибудь ценное. Ценной является готовность удержать.

Я делюсь своим опытом и своим личным терапевтическим стилем. В надежде, что мои наработки соединятся с какимито вашими личными наблюдениями и сомнениями. Но также понимаю, что попираю известные догмы, и любой из вас волен не согласиться и даже осудить меня.

Но мой опыт - это тоже опыт. И в моем опыте мои личные пациенты ни разу так и не злоупотребили моим вольным обращением как с аналитической нейтральностью, так и аналитическим сеттингом.

\section{Литература:}

1. Кляйн, М. (2001). Заметки о некоторых шизоидных механизмах. Кляйн М. и др. Развитие в психоанализе. М.: Академический Проект.

2. Кохут, Х. (2002). Восстановление самости.

3. Фрейд, 3. (2017). Я и Оно (сборник). Litres.

4. Фрейд, 3. (1984). Печаль и меланхолия. Интерес к психоанализу: Сборник/Пер. с нем, 228-247. 
DOI

\section{Елена Медведева}

Ph.D., клинический психолог,

Сертифицированный психоаналитик УАП-ЕКПП, практик и преподаватель психоанализа, лектор Международного института глубинной психологии https://orcid.org/0000-0003-2808-7622

\section{АВАТАР НА КУШЕТКЕ И СОПРОТИВЛЕНИЕ АНАЛИТИКА}

Марк Цукерберг дал Фейсбуку фундаментальное определение: “Это зеркало того, что существует в реальной жизни». Изменился ли субъект в виртуальном измерении, где отслеживается каждый шаг, где сети затягивают в свою пучину и воруют все свободное время, где существует настоящий рай для авантюристов и извращенцев, где любой пост может стать эпитафией? В связи с пандемией психоанализ вынужден был перейти в онлайн, но вызвал тревогу у психоаналитиков. В современном дискурсе, где виртуальное становится неотъемлемой частью жизни субъекта, что-то должно произойти и в психоаналитическом мире. Что мы можем предложить анализантам, преодолевая собственную тревогу и сопротивление?

*Аватар, кроме значения в индуизме как инкарнации божества, в современности означает персонаж некоей виртуальной реальности, игры, представляющий некоего действительно существующего человека или же маленькое изображение, представляющее определенного человека, пользователя витруальной реальности.

*Психоаналитик - это не только тот, кто слушает особым образом, интерпретирует, но и тот, кто ведёт человека в направлении столкновения с тем, что невозможно помыслить и представить. В этой логике аналитик - партнер, на которого 
будут направлены желания и ожидания определенного человека - субъекта речи, который высказывает, спотыкаясь в своем высказывании, оговариваясь, о субъективной истине.

«Психоанализ - это всё что угодно, но только не следование архаическим догматам», - предупреждает французский аналитик Жак Лакан. А итальянский психоаналитик Сержио Бенвенуто парирует: «Психоанализ - не физика, для которой невозможно выйти за пределы скорости света. Аргументы психоаналитиков, которые отрицают Скайп или другие коммуникационные мессенджеры, те же, что и учителей: нужно живое присутствие аналитика для аналитических отношений». «Святые слова, - говорит сеньор Бенвенутто, - но сказаны они в том мире, где нет давно ничего святого, в котором все течет, все изменяется».

Поразмыслим над этим.

Вопрос о виртуальном в психоанализе, понятно, стал особо острым после того, как мир столкнулся с пандемией и внезапно стал иным. До этого мы так же консультировали онлайн иностранных или иногородних анализантов, в том количестве и с теми подходами, которые для нас были приемлемыми, и соответствовали нашему желанию как желанию психоаналитиков.

Но в связи с локдаунами на аватарках психоаналитиков в мессенджерах повсеместно появились надписи «Консультирую онлайн» - таким образом специалисты вписались в критическую ситуацию. И получить помощь онлайн захотели многие в силу вынужденного ограничения передвижения, страха заболеть и прочих тревог, которые поднялись из-за непонимания и ужаса, связанного с распространением вируса.

Некоторые психоаналитические сообщества, особо тяготеющие к ортодоксальности, подняли бучу: так нельзя, нарушаются психоаналитические правила, невозможно услышать перенос, сопротивление, есть много странных особенностей в виде места, откуда выходит на связь человек, где он может 
уединиться - автомобиль или даже туалет. (Что, впрочем, тоже терапевтично для анализанта - обнаружить отсутствие места в доме и понимания близких.) Плюс, как мы знаем, важна психоаналитическая рамка кабинета, присутствие тела аналитика и анализанта, в конце концов. Ну вопрос этики. Другие же психоаналитические сообщества поддержали тех коллег, которые отозвались на изменения, задумались о поиске новых подходов, включились в переосмысление новых реалий, обозначили пути исследования этих перемен.

В любом случае возникает вопрос: почему это нас, психоаналитиков, так возбудило?

Начнем с того, что, конечно, интернет стал властителем мира. А веб-сайты - это настоящие видеоархивы жизни человечества. Социальные сети стали плацдармами воен, но и предупреждением их, опасностью и безопасностью: известно, что теракты, к примеру, и организовывались в соцсетях, и предупреждались службами безопасности там же.

Однако, ни одна социальная сеть не стала необычной, они типичны. Фейсбук стал продуктом подросткового самодельного Фейсмаш. Твиттер появился в результате поспешного отхода от неудачного сервера подкастов, который планировали для рейв-сцены Сан-Франциско, а Гугл начался с идеи двух стэнфордских молодых до разумных, которые хотели написать хорошую диссертацию. Да и Ютуб, появившийся в 2004 году благодаря пари Джастина Тимберлейка, который пообещал в прямом эфире раздеть Джанет Джексон, стал источником информации, как вы понимаете, случайно: никакая из компаний, участвовавших в трансляции Суперкубка 2004 не хотели скандала, видео обнаженной груди Джексон поторопились стереть, хотя его увидели миллионы зрителей прямого эфира, но оно осталась все же в записях, и его просто надо было положить в одном месте, доступном для поиска и обмена. Что, собственно, и было сделано. 
«Ты прекрасно выглядишь и я тебя люблю» - с такой фразы, очевидно, не начинают знакомства в Тиндер. Но она пригодилась для перечня типичных фраз, которые специалист по искусственному интеллекту Джанель Шейн научила читать компьютер. После этого искусственный интеллект, мозг, нейронная сеть выучила эти фразы и создала свою. Нейронные сети - новый тип компьютерных сетей, который вместо программирования опирается на формальную логику: если а =да, делай в, если а = нет, делай с. Нейронные сети напоминают живой мозг. Тут миллионы искусственных нейронов, которые устанавливают синапсы с тысячами других. Каждый имеет свою степень интенсивности и синаптические связи. Они функционируют путем узнавания систем, отслеживают ошибки в информационных колоссальных объемах, их тренируют с помощью процесса глубинного обучения. Сначала было дело под контролем человека. Сегодня уже без. Нескончаемый поток контента, создаваемого в интернете ежедневно, дает бесконечные данные для обучения этих все более умных машин. И они уже сами могут отбирать и присваивать информацию, пользоваться нею, создавать свой образ.

Более того, машины вторгаются и в поле речи, там где работают психоаналитики. Один из известных стартапов синтеза языка Lyrebird еще в 2017 году шокировал мир тем, что опубликовал запись убедительного и абсолютно фейкового разговора Барака Обамы, Хиллари Клинтон и Дональда Трампа. Другая компания презентовала инструменты редактирования, показав, что изменять или добавлять новые биты языка к файлу можно также, как и к изображению.

Нейронные сети могут синтезировать то, что мы читаем и слышим, что присваиваем от других, то, что видим. Например, мир облетела трехмерная фотореалистичная модель лица известного боксера Мухаммеда Али. Это гиперреалистичное лицо, готовое к помещению в виртуальный мир, и машины 
способны переписать историю того, что делал и что говорил Мухаммед Али, когда был жив. И возникает вопрос: где разница между хорошим и плохим искусственным интеллектом, опасным и безопасным, и какой из них будет побеждать? От этого зависят не только судьбы политики, войн, выборов, демократии, цивилизации и объективной реальности. Машинный интеллект будет вести битву с другими машинными интеллектами, а посредине окажемся мы, как часть конфликта, который мы начали, но на динамику развертывания которого вряд ли уже сможем повлиять.

Нет ни одного исторического примера, аналога быстроте и тотальности, с какими платформы соцсетей завоевывают планету. Идею телеграфа внедряли на протяжении двух поколений, а Интернет появился в правительственных лабораториях США на протяжении нескольких десятилетий. Изумились творцы социальных сетей, когда их платформы получили тысячи, миллионы, миллиарды пользователей, они даже не представляли, как их системы можно использовать. Они просто хотели заработать денег. Все онлайн платформы - это предприятия для бизнеса. Но никто из их основателей и не мечтал о такой популярности. Это произошло само собой. Сегодня социальные сети, месенждеры очень влиятельные, легкодоступные и гибкие. В каждой идет битва не столько актуальных вопросов, сколько за будущее. Исследователи Брукинг и Сингер в работе «Война лайков» говорят, что это будущее похоже на научную фантастику, однако выглядит удивительно реалистично.

Окей, Гугл!

Люди все же уникальны в своей способности учиться и эволюционировать, изменять структуру окружения. Хотя Интернет породил драматические новые силы, эти изменения еще далеки от неизведанного и незнаного. Нашу тревогу может снять понимание, что современное информационное про- 
странство все же стабильно, Интернет остается в предсказуемом будущем одним из главных способов коммуникации, он будет масштабироваться, но информационная экосистема не изменится, она достигла точки зрелости. Интернет, конечно, поле битвы. А человек все же борется за то, что действительно имеет для него значение: признание, внимание и вовлеченность. Интернет изменяет способ нашего восприятия информации. Сфабрикованное событие, сфабрикованная жизнь напоказ может иметь силу, так как люди это верят. Это битва за манипуляцию, которая одновременно делает все прозрачным, но и легко затененным. А мы все - часть этой битвы. Нас окружает информационная борьба и очевидная, и невидимая, которая стремится изменить наше восприятие мира. Мы лайкаем и расшариваем, и нет тут нейтральной территории.

Самое важное, в этом эволюционном процессе нет ничего экстраординарного. И его можно помыслить с помощью известной притчи, наистарейшей в истории человечества, которая берет начало из индуистских и буддистских текстов, написанных почти четыре тысячелетия назад. Это притча о слепых и слоне. Группа незрячих ощупывают слона и представляют много разных объектов: змею, дерево, стену - и начинают драться из-за несогласия. Индуистская Ригведа подытоживает рассказ так: «Реальность одна, хоть мудрец говорит о ней по-разному». Когда есть сомнения, нужно искать иную мысль, другую, третью, четвертую.

Кто такой Аватар? - человек со своей истиной и представлением о себе для другого. Но чем он отличается от того, кто появляется в нашем кабинете? Знаем ли мы нашего анализанта, правду его или правду о нем. Нет. У нас есть его речь и его субъективная истина. И она может появиться как оффлайн, так и онлайн. Понятие «субъект» Лакан постоянно перерабатывал, но всегда в сопряжении с бессознательным, как эффектом языка. Такой себе Вайфай бессознательного. Субъект 
Лакана изначально обозначен как пребывающий в отношениях с большим Другим, который представлен или другим субъектом, или местом, в котором загодя сформирована, сформулирована речь. Эти отношения поддерживает регистр символического, где субъект бессознательного проявляется на уровне акта высказывания - в образованиях бессознательного, таких как симптомы, сновидения, ошибочные действия и остроты, то есть там, где речь идёт о сингулярных проявлениях сексуированного в своей сущности желания. Регистр символического опирается на исконный сбой человеческой внеприродной (психо)сексуальности. Регистр символического задаёт режим уникального, непредсказуемого интерсубъективного взаимодействия, и повторения в смысле производства новизны.

Я думаю, что одни психоаналитики несколько растерялись перед этим новым виртуальным, может быть, даже возмутились тем, что все идет не по правилам, принятым когда-то, но стали изучать, осмыслять: кто же теперь их анализант, каков он, как его услышать, и что может изменить в отношениях аналитик-анализант. Другие стали отрицать неизбежность прогресса и утверждать, что человека нужно вернуть назад, куда, правда, неясно, потому что присутствие якобы третьего - монитора, то есть некоей машины, которая якобы тоже оказалась «очеловеченной», а так же виртуального пространства, не кабинета, не позволяет развиться анализу, мешает слушать и слышать.

Я хотела бы здесь напомнить о том, что третий все же в аналитическом акте - речь, высказывание, а не экран. Организация психоаналитического процесса онлайн - это теперь не только место, в которое говорит анализант, это и особенное место, с которого говорит анализант. Это виртуальная кушетка, но речь звучит. Анализант так же ассоциирует, ошибается и проговаривается. Вопрос - преодоления сопротивления самого психоаналитика. Я бы хотела напомнить о довольно важных постулатах, оставленных нам классиками психоанализа. 
Фрейд пишет статью «Сопротивления психоанализу» в сентябре 1924 года. Обратим внимание на ее название. Речь здесь идет не о «сопротивлении психоанализу», а о сопротивлениях во множественном числе. С тех далеких пор некоторые сопротивления, похоже, ослабли, другие, напротив, усилились. Более того, появились новые причины для сопротивления. Кроме того, сопротивления эти во многом были и остаются феноменом не только «внешним», но и «внутренним». Можно сказать, что психоанализ подвергается атаке не только и не столько извне, сколько изнутри. Можно представить три разных фронта сопротивлений. Во-первых, сопротивление, конечно же, сначала было обнаружено Фрейдом как феномен клинический, как линия фантазматического фронта в психоаналитическом кабинете и именно превращение сопротивления из препятствия анализу в средство анализа стало одним из оснований рождения психоанализа.

Во-вторых, можно говорить о сопротивлениях психоанализу со стороны внешней - медицины, средств массовой информации, того же интернета, социальных сетей. В-третьих, о сопротивлениях внутренних, исходящих от самих психоаналитиков. Это сопротивление связано с вопросом о пределах психоанализа, о границах, которые никому так и не удалось провести, и это не случайно.

Внутреннее сопротивление психоанализу - сопротивление психоанализу от имени психоанализа. Фрейд оставил открытую систему, и, если психоанализ пересобирается каждый раз заново в зависимости от сингулярного случая, всегда уже остается место для других истолкований, всегда уже сохраняется неанализируемый остаток. Отношение к новому Фрейд начинаетс отношения к новому младенца, суеверного, крестьянина: «Когда грудной ребенок, находясь на руках у няни, с криком отворачивается от незнакомого лица, когда набожный человек начинает новый день молитвой или благословляет 
плод, который он впервые вкушает в этом году, когда крестьянин отказывается купить косу, на которой нет одобренной его родителями фабричной марки, то различие всех этих ситуаций очевидно, и было бы, по-видимому, правильно искать отдельный мотив для каждого из них». Весьма своеобразно Фрейд приводит три примера не для того, чтобы указать на сходство неодинаковых, на первый взгляд ситуаций, но чтобы заключить об их различиях. Для наших рассуждений этот момент принципиальнейший: психоанализ работает с сингулярностями. После неожиданного различающего хода Фрейд все же обращается к аналогии и обнаруживает кое-что общее для всех трех случаев, а именно неудовольствие, причиняемое «теми требованиями, которые предъявляет к душевной жизни новое, та психическая затрата, которой оно требует, та повышенная неуверенность, которую оно приносит с собой и которая может доходить до ожидания, исполненного страха» .

В «Автопортрете» Фрейд, различая свой подход от теорий Юнга и Адлера, говорит о своем стремлении пройти между бессистемностью и жесткой системой, т. е. по сути дела пишет о желании создать открытую систему, в которой «концепты соотносятся с обстоятельствами, а не с сущностью». Открытость фрейдовской системы настоятельно подчеркивает и Лакан: «Мысль Фрейда более чем какая-либо открыта пересмотру», а Фуко вообще называет Фрейда одним из основателей дискурсивности, установившем «некую бесконечную возможность дискурсов».

Новое нарушает принцип удовольствия, преступает установленный им режим экономии, выводит из равновесия. От этих примеров Фрейд постепенно переходит к к психоанализу, но сначала к науке и к ее должному бесстрашию: «В научной области не должно быть места такой боязни нового. В ее вечном несовершенстве $и$ неполноте науке предназначено связывать свое развитие с новыми открытиями и новыми понятиями. 
Чтобы не быть введенной в заблуждение, она поступает правильно, вооружившись скептицизмом, не принимая ничего нового, не подвергшегося строгой проверке». Но скептицизм оборачивается своей другой стороной: «Он резко ополчается против нового, в то время как почтительно относится и щадит то, что уже известно и заслужило его доверие, и он довольствуется тем, что отбрасывает новое еще прежде, чем исследует его. Но тогда он предстает перед нами как продолжение примитивной реакции на новое, как личина для сохранения ее». Априорное отрицание нового сближает научный консерватизм с повседневной реакцией ребенка, набожного и крестьянина. И психоанализу, где, казалось бы, «не должно быть места такой боязни нового", оказывается свойственна неофобия.

Сопротивление, повторю - покров неофобии, отмеченной нарушением экономики принципа удовольствия. Новое же лишь отверстие для прорыва старого. Новое может вызывать сопротивление не только как что-то новое, но как хорошо забытое старое. Иначе говоря, новое может вызывать страх как хорошо известное неизвестное, как возвращающееся вытесненное, как до боли знакомое нераспознаваемое.

«Сопротивления психоанализу» указывают на, по меньшей мере, три комплекса, три мыслительные сферы: сексуальности, культуры и нарциссизма. Иначе говоря, все обращается вокруг того, что делает человека человеком. Все вращается вокруг трех травматических зон. Сопротивление вызывают сами механизмы субъективации. Субъект рождается в сопротивлении. Субъект рождается в культуру в сопротивлении культуре, в реорганизации либидо, в социализации нарциссизма.Смысл психоанализа учреждается в субъективности его истины. Истина не предшествует субъекту. Она конституируется по мере конституирования самого субъекта. В то же время следует отметить, что изменились отношения не только науки с «новым», но и психоанализа с «новым». Сопротивление вообще 
оказывается приписанным с этой точки зрения воображаемому порядку и берет в нем свое начало. Объясняется это, исходя из того, что Лакан называет новой линией раздела в психике, появляющейся в «По ту сторону принципа удовольствия»: она проходит не между сознательным и бессознательным, а между стремящимся к самоповторению вытесненным и собственным я. Последнее и оказывается источником сопротивления. Сопротивление субъекта - это именно сопротивление анализу, сопротивление в анализе, сопротивление, вызываемое аналитиком. В конечном счете, согласно формуле Лакана, «нет иного сопротивления анализу, кроме сопротивления самого аналитика». Аналитик сам может оказаться в капкане сопротивления.

Психоанализ, конечно же, существует в культуре, на ее полях, на ее пределах и занимает маргинальную позицию в отношении господствующей культуры, которая позволяет ему культуру испытывать. Как часть культуры психоанализ не может испытывать ее извне, но может стремиться занимать предельно внешнюю позицию внутри. Здесь содержится парадокс не только места: оказываясь на полях культуры, психоанализ не требует отмены культурных запретов, не требует удовлетворения желаний. И он не за «раскрепощение наших общественно вредных влечений». Мишель Фуко в «Словах и вещах» пишет: «Фактически психоанализ ближе всего подходит к осуществлению той критической функции, которая, как мы уже видели, внутренне присуща всем гуманитарным наукам. Задаваясь целью заставить бессознательное говорить сквозь сознание, психоанализ устремляется в сторону той основополагающей области, в которой разыгрываются отношения представления и конечного человеческого бытия».

Психоанализ поддерживает свое существование, пока не забывает о критической функции, пока не принимается адаптировать человека к репрессивной культуре, пока не обслуживает систему. Лакановская мысль такова: аналитик образовывается 
в качестве такового, когда желание анализировать становится больше желания проявлять личностные и чувственные реакции. До тех пор, пока для специалиста больший интерес, вопрос или проблему представляет сфера воображаемого, пока он остаётся захвачен собственными «нарциссическими миражами», говорить о психоанализе не приходится.

Психоанализ - это этика. В первую очередь это этика дискурсивной позиции, которая не позволяет судить другого и принимать за него решения. Мы работаем, пока не исчез мыслящий, желающий субъект. Он, возможно, сегодня находится в опасности стать придатком айфона или смартфона, но мы можем ему предложить пространство, время и место, чтобы оставаться субъектом нуждающимся и повторяющимся, страдающим и желающим. Субъект - подчиненный, подданный культуре, языку. Субъект психоанализа как субъект культуры это субъект исторический, меняющийся в зависимости от господствующей веры в те или иные положения религии, науки, идеологии. Субъект - совсем не «единичное природное существо», а подданный постоянно меняющейся культуры. Фрейд не раз писал о том, что его детище, психоанализ, не имеет определенного места в культуре. Но искусство психоанализа нацелено на изменение судьбы человека в культуре.

Пандемия вируса из тела перешла в социальные сети и стала рассадником дугого вируса, фейкового, тревожащего еще сильнее. Также пандемия показала, что мир точно не будет прежним. Вынужденная эвакуация в виртуальный мир вынуждает нас изменить свои привычки, правила, но и вызывает сопротивление, которые, как считает Сержио Бенвенутто, вполне может быть аргументировано аналитичками и интеллектуалами. Но так уже было: появился телевизор - вредно, компьютер еще вреднее. Но тем не менее он стал источником и способом работы, учебы, досуга. Но как понятно, что худшие способы использования нового объекта вызывают дискредитацию самого 
этого объекта. То же относится и к месенджерам. Скайп не может быть психоаналитическим, - твердят многие специалисты, и находят аргументы. Да, теоретически мы можем назвать нюансы, особенности и некие невозможности работы с определенными психическими структурами. Но эта эволюция (или революция?) все равно состоялась и будет продолжаться, и, скорее всего теория тоже адаптируется к новым реалиям. Фрейд раньше тоже утверждал, что психоанализ невозможен для детей, взрослых после 50 лет, психотиков и первертов, не говоря уже о группанализе. Но его последователи открывали новые возможности.

Уильфред Бион считал, что мы можем говорить о совместном опыте анализанта и аналитика, и предположил использование внутренних психических процессов аналитика как возможность для понимания бессознательных процессов пациента. Но при этом, если аналитик вмешивает себя в это пространство, это будет ошибкой, по мысли Биона. Терапевтическая ситуация развивается в контексте отношений между аналитиком и анализантом, и, в связи с этим можно предполагать, что если есть перенос, то неизбежны и ответы аналитика, которые артикулируются в феномене контрпереноса или же сопротивлении. То есть, это реакции, которые могут отражать и собственные проблемы, и конфликты аналитика, которые внедряются в аналитические отношения. Жак Лакан пишет, что преградой на пути установления в анализе интерсубъективной истины оказывается образ. Перенос в этом случае замораживает диалектику субъекта, погружая его в воображаемые отношения. Будучи воображаемым, перенос образов оказывает сопротивление истине. Субъект преодолевает это сопротивление, когда ему удается спроецировать свое прошлое в диалектику символических отношений. Перенос - метафора любви. Любящий субъект любит, поскольку у любимого есть неизвестный объект, которого нет у него. Лю- 
бовь - всегда знак перемены дискурса. Динамика переноса динамика любви. Любовь и ненависть - две центральные составляющие символического и воображаемого переноса. Воображаемые отношения с другими воздействуют на психотическую позицию в рамках переноса. На семинарских занятиях 1960/61 годов перенос у Лакана претерпевает буквальное перемещение. Он теперь исходит не от анализируемого, а от желания аналитика, занимающего вакантное место желания Другого. Аналитик занимает ключевую позицию в провоцировании символического переноса, поскольку воплощает функцию знающего. Контрперенос - не какой-то отдельный феномен, но неотъемлемая составляющая переноса. Аналитик неизбежно вовлечен в перенос. 19 марта 1974 года Лакан делает радикальное заявление: в психоанализе существует только один перенос - перенос аналитика.

Осмысляя эти феномены, все же нам стоит пересмореть свое сопротивление новому и этому образу некоего «другого", который вторгается в процесс (или изменяет его, по-особому раскрывает?). Думаю, наша позиция в отношении анализа онлайн все же может обращена не только к реалиям времени как таковым, но и возможностью предоставить анализантам время, место, пространство, безопасное и продуктивное, отличное от того виртуального, в котором бывает страшно, одиноко, где пост может стать эпитафией, где развязываются войны, ведется слежка за каждым словом и действием... 
DOI

\section{Мария Евграшина}

Сертифицированный психоаналитик ЕКПП, практик и преподаватель психоанализа супружеских пар (Берлин, Германия), член Дивизиона "Психоаналитическая психология и психотерапия" Национальной психологической ассоциации Украины https://orcid.org/0000-0003-3490-9039

\section{ТЕЛЕСНОЕ СОПРИСУТСТВИЕ: АСПЕКТЫ РАБОТЫ В РЕАЛЬНОМ И ВИРТУАЛЬНОМ ПРОСТРАНСТВЕ}

«Тело создается разумом» Ф. Шиллер

Когда мы находимся в одном физическом пространстве с нашими анализантами, мы присутствуем друг для друга в телесном воплощении, и это не нуждается в уточнении. Что же происходит, когда само пространство претерпевает метаморфозы?

\section{Метаморфозы психоаналитического пространства}

\section{от кушетки к Скайпу}

В книге Харольда Стерна (Harold Stern, 1978) «Кушетка. Eе значение и использование в психотерапии» говорится: «Блестящее зеркальце на лбу доктора говорит о том, что это врач «ухо-горло-нос», черный резиновый молоточек говорит о невропатологе, скальпель - о хирурге, а психоаналитика узнают по кушетке в его кабинете».

Какова же роль кушетки в психоаналитическом пространстве? Для психоаналитика это символическое напоминание, которое отмечает его уникальный опыт, проводя границу между психоанализом и другими видами психотерапии. Конечно же, ее роль в процессе работы сложно переоценить. 
Складывается впечатление, что кушетка репрезентует сам психоанализ. Фильмы, книги, карикатуры - психоаналитик в них всегда угадывается по наличию кушетки. Первое в технике психоанализа, с чем сталкивался каждый будущий аналитик, это кушетка, которая навсегда останется частью собственного анализа.

Несомненно, кушетка - эмблематический объект психоанализа. Но, в то же время, не она определяет психоанализ. Например, психоаналитическая работа лицом друг к другу, где пациент сидит в кресле, также может хорошо продвигаться. Иными словами, использование кушетки должно сохраняться, пока оно вносит вклад в специфику излечения пациента, но не является его обязательным условием.

Приведу клинический пример. Ко мне обратилась женщина 30 лет с жалобами на непринятие себя и своего образа тела. «Мое тело - как плохо сидящая одежда», - часто повторяла она. Брошенная матерью в раннем возрасте, она знала ее лишь по фотографиям, от которых при этом была отрезана нижняя половина: возможно, мать тоже испытывала неприязнь к некоторым частям своего тела. Работа продолжалась в течение 3 лет на кушетке. В положении лежа анализантка все время крутилась, переворачивалась то на бок, то на живот, изредка задерживаясь на спине. Долгое время невозможно было подступиться к символизации этого телесного отреагирования. Каждая сессия начиналась с того, что она быстро пробегала к кушетке, не встречаясь со мной взглядом, и точно также поспешно удалялась в конце. Как не существовала она для своей матери, так пыталась не существовать и для своего аналитика, и лишь движения на кушетке «говорили», что она жива. Представить себя взгляду другого было для нее непосильной задачей, и только когда, спустя какое-то время, мы перешли к работе лицом к лицу, процесс присвоения себе своего тела посредством взгляда другого смогла продвинуться. 
Этим клиническим примером хотелось проиллюстрировать важность понимания применения того или иного инструмента в своей работе. Мы не делаем это без достаточных оснований: будь то переход от кушетки к работе лицом к лицу, или когда перемещаемся в Скайп.

Поэтому, когда на арену выходит «телеанализ» или «онлайн-психоанализ», мы сталкиваемся с ревизией метода. В чем она состоит? Что мы наблюдаем при переходе в Скайп?

Когда я говорю о Скайпе, я имею в виду не только его, но и все доступные сегодня средства связи: Zoom, WhatsApp, Viber и т.п. Несмотря на то, что на сегодняшний день достаточно много литературы по теме работы в онлайн-режиме, интенсивность жизни и появление новых технологий вносит все новые и новые коррективы. Еще 7-8 лет назад работа по Скайпу предполагала компьютер или ноутбук. В этом случае лица на экране сопоставимы с оригинальной величиной. Сегодня это уже не так. У наших анализантов есть телефоны, и мы не можем контролировать, через какое устройство они выходят на связь. Лицо психоаналитика без его ведома может быть уменьшено до размера руки или, наоборот, транслироваться на огромном экране, где окажется в несколько раз больше своего реального размера.

Следующий важный вопрос - что является местом встречи? Можно ли назвать им Скайп? И да, и нет. Мы встречаемся посредством Скайпа, но кто к кому приходит на самом деле: анализант в наше пространство, или мы в его? Устанавливает ли Скайп границу? Анализанты появляются на нашем экране в пижамах, с чаем и едой, они могут находиться в постели, попасть в пробку и пытаться звонить нам на ходу из машины, пойти в кафе и общаться оттуда, или даже выйти из дома в парк - почему бы не пообщаться с аналитиком на природе? Безусловно, это все важные моменты для исследования в процессе терапии, но одно можно сказать точно: это не то же 
самое, что работа в кабинете. Одна моя анализантка, перейдя от работы через экран компьютера к телефону, пояснила это следующим образом: «Мне нравится знать, что вы всегда со мной - в кармане».

Я не случайно начала свой доклад с кушетки, так как Скайп тут как кушетка, разговоры о целесообразности применения которых не угаснут, вероятно, никогда.

Мой первый опыт работы по Скайпу случился 7 лет назад. Когда возникла такая необходимость, появились вопросы: будет ли это психоанализом? Сохранится ли работа? Как ее лучше проводить? С этим анализантом мы начали работу в кабинете, он лежал на кушетке. Через некоторое время ему пришлось по работе переехать в другой город, и мы приняли решение продолжить работу по Скайпу без видеотрансляции. Нашей формой связи оставался только голос. В такой конфигурации процесса ухо аналитика становится очень чувствительным к любым вибрациям голоса анализанта, резонируя с ним. Происходящее было совершенно непохоже на привычный вариант взаимодействия. Казалось, это форма бестелесного присутствия. Закономерно возникли вопросы: так ли на самом деле? Не утрачиваем ли мы что-то в таком формате работы? Что именно меняется? И все-таки - какую роль в этом процессе играет телесность?

Начнем с того, что меняется формат совместного присутствия.

\section{Теле-соприсутствие:}

теле(сное) или теле(коммуникационное)?

На сегодняшний день можно условно выделить такие формы сеттинга при онлайн-работе:

- Очные встречи в первой части терапии с работой лицом к лицу, далее - онлайн-терапия с видеосвязью;

- Очные встречи в первой части терапии с работой на кушетке, далее - онлайн-терапия без видеосвязи; 
- Только онлайн-терапия с видеосвязью без очных встреч;

- Онлайн-терапия и эпизодические очные встречи;

- Очные встречи и эпизодическая онлайн-терапия;

- Онлайн-терапия, когда экран стоит у изголовья дивана, на котором лежит анализант: аналитик видит анализанта, а анализант аналитика - нет.

У каждой формы есть свои достоинства и недостатки, свои особенности и свои подводные камни. Дальнейшие рассуждения ведутся для форм сеттинга, где работа ведется в онлайн-формате продолжительное время и очные встречи не нарушают ее ход.

Что же подразумевается под «соприсутствием»?

Соприсутствие здесь определяется как форма совместного пребывания людей, в которой они становятся друг для друга доступными, достижимыми и взаимодействующими. Другими словами, это состояние, при котором имеют место мгновенные двусторонние человеческие взаимодействия. Под «мгновенными» подразумевается взаимодействие в реальном или близком к реальному времени (а не как, например, обмен сообщениями в переписке).

Профессор социологии Темпльского университета Shanyang Zhao в 2003 году написал статью «О таксономии соприсутствия», выделив разные формы соприсутствия и задавшись вопросами: где и как присутствует другой:

\begin{tabular}{|c|c|c|}
\hline $\begin{array}{c}\text { Где находится другой? } \\
\text { Как присутствует } \\
\text { другой? }\end{array}$ & $\begin{array}{c}\text { Другой находится } \\
\text { физической близости }\end{array}$ & $\begin{array}{c}\text { Аругой находится } \\
\text { в электронной } \\
\text { близости }\end{array}$ \\
\hline $\begin{array}{c}\text { Другой присутствует } \\
\text { лично }\end{array}$ & $\begin{array}{c}\text { Телесное } \\
\text { соприсутствие } \\
\text { (лицом к лицу) }\end{array}$ & $\begin{array}{c}\text { Телесное } \\
\text { телесоприсутствие } \\
\text { (лицом к устройству) }\end{array}$ \\
\hline $\begin{array}{c}\text { Другой присутствует } \\
\text { посредством симуляции }\end{array}$ & $\begin{array}{c}\text { Виртульное } \\
\text { соприсутствие } \\
\text { (физическая симуляция) }\end{array}$ & $\begin{array}{c}\text { Виртуальное } \\
\text { телесоприсутствие } \\
\text { (цифровая симулячия) }\end{array}$ \\
\hline
\end{tabular}


В этой таксономии наш интерес представляет первая строка, хотя вторая уже не за горами.

Телесное соприсутствие - древнейшая форма совместного присутствия людей, которая нам хорошо знакома. В категориях работы в кабинете можно сформулировать, что аналитик и анализант находятся в телесном соприсутствии, находясь в физической близости в пределах досягаемости органов восприятия друг друга.

Телесное теле-соприсутствие или телесное дистанционное соприсутствие (bodily telecopresence) - когда психоаналитик и анализант находятся в такой форме человеческого совместного нахождения, в которой оба человека присутствуют лично на своих локальных сторонах, но по отношению друг к другу они расположены в электронной близости, а не в физической. Несмотря на то, что они находятся вне пределов восприятия чувств друг друга, они находятся в непосредственной близости друг от друга через сеть электронных коммуникаций.

Чувство соприсутствия - это субъективный опыт индивидуального пребывания вместе с другими людьми. Физическое присутствие в одном пространстве, несомненно, порождает самое яркое чувство соприсутствия. Однако сегодня средства телекоммуникации позволяют людям видеть и слышать друг друга так, как если бы они телесно присутствовали друг для друга. Сильнейшее опосредованное чувство соприсутствия иногда определяют как «перцептивную иллюзию отсутствия посредничества» (Lombard and Ditton, 1997).

\section{Участие телесных процессов \\ в психоаналитическом процессе}

Дистанционному психоанализу часто вменяют отсутствие так называемой межтелесности. Этот аргумент правдоподобен только на первый взгляд. Приравнивание физического присутствия и межтелесного функционирования в классическом аналитическом сеттинге заставляет насторожиться. 
Область психоаналитических исследований телесных процессов переноса, контейнирования, трансформации телесного напряжения в ревери и т. д. не исчерпана, и в контексте работы онлайн находится в самом начале. Невозможно ни утверждать, что все эти процессы автоматически выполняются в физическом пространстве (что определенно не так), ни отрицать, что они полностью отсутствуют при дистанционной работе. Также невозможно однозначно сказать, что подходы, хорошо работающие в обычных условиях, в онлайн-терапии обречены на провал. Вероятно, психоанализу следует дать время на изучение этих аспектов в контексте традиционного и дистанционного психоанализа.

Тем не менее, уже сейчас мы можем сказать, что физическое присутствие аналитика никоим образом не гарантирует сонастройки терапевтической диады на уровне телесных процессов. И наоборот, телеанализ не лишен телесности. И аналитик, и анализант физически вовлечены в терапевтический процесс, но среда взаимодействия другая. Скайп, Zoom, телефон или любой другой носитель не преобразует речь анализанта в цифровые знаки, а передает все элементы того, что разыгрывается на терапевтической сцене: голос, интонации, жесты, выражение лица, и на самом деле всю ту особую атмосферу, которая создается между аналитиком и анализантом. Звук голоса аналитика сам по себе вызывает отклик в теле анализанта и, наоборот, когда аналитик не может видеть телесный ответ анализанта, он пользуется другими наблюдениями, такими как запинания, слезы, улавливание дыхания и изменения тона, которые показывают гораздо больше, чем слова сами по себе. В дополнение к речи, мыслям и свободным ассоциациям анализант также может объединить свои телесные ощущения, психосоматические симптомы и состояния напряжения в ассоциативную цепочку. Со своей стороны аналитик, слушая речь, опирается не только на семантику (смена 
вокального звучания может указывать, например, на регрессивное отклонение, или на определенные эмоциональные контуры), но также может обрабатывать свои собственные физические реакции, резонансы и, собственно, контрперенос.

Можно сказать, что Скайп, «подобно кушетке, изменяет параметры невербальной среды: он де-акцентирует или устраняет некоторые из них, в то время как подчеркивает другие” (Leffert, 2003). Согласно тому, на чем настаивал Фрейд, аналитик «должен превратить свое собственное бессознательное в рецептивный орган в направлении бессознательного пациента» (Freud, 1912). И это «формула» остается неизменной для психоаналитической работы в любом формате.

Слова отлично передаются по Скайпу или телефону. Если бы психоанализ был терапией «только на словах», проблем бы не возникало. Таким образом, проблему и частичное решение следует искать в области, выходящей за рамки вербального, т.е. в довербальном. Но что такое «довербальное»? Довербальное определяется как событие «до», «еще не», «не полностью», которое достигает своей кульминации в слове. А слово, как нам известно из концепции довербального, является венцом терапевтического процесса, и все, что происходит раньше, каким-то образом является другим - таким, которое едва ли можно исследовать: это просто «до».

Но что это за «до»? Куда мы попадаем за границами языка? Есть ли в подобной бессловесности слова?

Тем не менее, в этой области существует хорошо структурированный порядок: взаимодействие матери и ребенка как окружающая среда, которая сначала не отделена от ребенка; позже постепенно появляется сепарация между «не-Я» и «я»; и далее - восприятие матери как части внешнего мира. (Д. Винникотт «Игра и реальность»). Прелингвистический ребенок способен распознавать эту окружающую среду, выражать свои эмоции и взаимодействовать в соответствии со сво- 
ими желаниями до того, как овладеет языком. Формирующаяся система выражения и распознавания символов оттачивается всю жизнь, и, помимо языка, образует важную систему коммуникации и регулирования отношений. В дополнение к этому само тело и телесные процессы являются отдельной системой памяти, где хранится представление о связи телесных иннерваций с эмоциональными импульсами.

Концепция ментализации Питера Фонаги (P. Fonagy, 2001) является актуальной версией обнадеживающего убеждения, что все системы изменяются в результате работы речи. Нейробиологическая точка зрения (J. Bauer, 2019) вторит этой идее: «Лингвистические послания от одного человека к другому воздействуют на нейробиологические структуры и могут вызвать биологические изменения в другом человеке». Таким образом, можно сказать, что аналитическая работа позволяет работать всем системам анализанта.

В своей одноименной статье Sebastian Leikert (2019) задается вопросом «Сколько тела переносится через Интернет?». Отвечая на этот вопрос, он предлагает в дополнение к вербальной и визуальной системам репрезентации также обратить внимание на третью систему - само тело. Leikert утверждает, что в телеанализе чувственные элементы передаются через звуки голоса и вызывают у аналитика телесный резонанс. Таким образом, настаивает он, хотя телеанализ и не способствует межтелесному взаимодействию, но этот недостаток можно компенсировать, если обращать внимание на телесные ощущения и вводить их в речь.

Хочется еще раз подчеркнуть - то, что не произошло «фактически», а только было передано лингвистически, имеет огромное значение. Речь производит такой же эффект, как и фактическое событие. И хотя мы не находимся в одном физическом пространстве, мы находимся в соприсутствии, где разворачивается психоаналитическая работа. 


\section{Проиллюстрирую это клинической зарисовкой.}

Мужчина 35 лет обратился с жалобами на навязчивые мысли, которые преследовали его почти всю жизнь. Работа на кушетке происходила в течение 4 лет. После моего переезда в Берлин мы продолжили работу по Скайпу, которая продлилась еще полтора года. Переход из кабинета в Скайп вызвал много сопротивления и агрессии. Так же в тот период он начал жаловаться на боли в животе, которые носили спонтанный характер и отчетливо проявлялись только на наших сессиях. Когда я попросила его описать, где эта боль локализована и на что похожа, он сказал, что боль находится в районе пупка и напоминает «тугой узел». Разворачивая эти ассоциации, анализант вспомнил, как в 16 лет ему удалили кисту урахуса, которая, как оказалось, возникла у него после отъезда из дома, когда на телесном уровне пришлось «отрезать пуповину от матери". Здесь довербальный опыт связанности с матерью смог стать облаченным в слова. Развязывание «тугого узла» происходило посредством интенсивной работы над телесными ощущениями и дифференциации соматических следов из истории, но поворотным пунктом стало описание этого «тугого узла», когда появилась связь между точной локализацией в теле и спонтанной визуализацией инкапсулированного образа телесного ощущения. Далее последовала работа по «развязыванию узла", когда паттерн дисфункциональной иннервации интегрировался в целостность самого тела, что ознаменовало приближение к процессу окончании терапии.

\section{Выводы}

Подводя свои размышления к концу, хочется отметить, что речь несет в себе не только значение слов или смысл сказанного, в ней также присутствует довербальное - как минимум в звучании. Нам не обязательно идти на концерт классической музыки, чтобы почувствовать эмоциональные вибрации души; запись концерта - будь то на пластинке или даже в 
цифровом виде - также вызывает эмоциональный резонанс. Вряд ли мы можем сказать, что, воспринимая только на слух, мы теряем способность чувствовать. Аналогично при работе через Скайп включаются те же телесные ощущения, как и при работе в кабинете. И, как в случае последней клинической виньетки, это лучшая альтернатива прекращению работы. Ориентация на аналитические идеалы, безусловно, важна, но забота о благополучии анализантов должна играть решающую роль.

Не стоит рассматривать это как призыв к онлайн-терапии вряд ли Скайп когда-либо станет символом психоанализа. Онлайн-терапия, телеанализ, несомненно, являются вторым вариантом, и его следует использовать только в том случае, когда другого способа взаимодействия с анализантом действительно нет - а 2020-2021 годы показали нам, что этот «второй вариант» может надолго стать единственно возможным.

Несомненно, психоаналитическая онлайн-работа усложняет взаимодействие, особенно в физическом плане, требуя большей концентрации на смысловом и кинетическом резонансах. Но как раз в силу того, что здесь перед нами стоит более сложная задача, важно иметь концепции, которые помогут справиться с телесными аспектами такой работы. Чем больше мы об этом размышляем, тем сильнее это может обогатить нашу кабинетную практику как в работе на кушетке, так и лицом к лицу. Внимательность к телесным процессам анализанта не привязана к конкретным условиям.

Завершу тем, что предпочтение в психоаналитической работе всегда остается за кабинетом и кушеткой, но в то же время хочется призвать к реализму относительно отклонений от классического сеттинга, которые становятся неизбежными в сегодняшней реальности. Теории техники онлайн-психоанализа еще предстоит наполнение, особенно в отношении телесных аспектов. Однако мы уже имеем опыт, когда психоанализ расширился за счет детского и группового анализа, что только 
обогатило его. Так почему бы не посмотреть на возможности онлайн-психоанализа творчески, не отходя от его сути?

\section{Литература:}

1. Винникотт, Д. (2002). Игра и реальность. М.: Институт общегуманитарных исследований, 288.

2. Стерн, Х. (2002). Кушетка: ее значение и использование в психотерапии. СПб.: Вост.-Европ. ин-т психоанализа, 188-206.

3. Freud, S. (1912). Recommendations to physicians practising psycho-analysis. London.

4. Scharff, J. S. (2013). Technology-assisted psychoanalysis. Journal of the American Psychoanalytic Association, 61(3), 491-510.

5. Bauer, J. (2019). Wie wir werden, wer wir sind: Die Entstehung des menschlichen Selbst durch Resonanz. Karl Blessing Verlag.

6. Fonagy, P. G., Jurist, G., \& Target, E. M. (2002). Affect Regulation, Mentalization, and the Development of the Self ed. New York, NY: Other Press. 203-251.

7. Leffert, M. (2003). Analysis and psychotherapy by telephone: Twenty years of clinical experience. Journal of the American Psychoanalytic Association, 51(1), 101-130.

8. Leikert, S. (2021). Wie viel Body überträgt sich via Internet?. Psychoanalyse im Widerspruch, 31(1), 27-47.

9. Lombard, M., \& Ditton, T. (1997). At the heart of it all: The concept of presence. Journal of computer-mediated communication, 3(2), JCMC321.

10. Zhao, S. (2003). Toward a taxonomy of copresence. Presence, 12(5), 445455. 
DOI

\section{Ярослава Бутенко-Гачковская}

Психоаналитический психолог, клинический психолог, консультант бизнеса, глава Ассоциации психоанализа в бизнесе в Украине, Директор и основатель Института Субъекта "Institute de Sujet" (Киев)

https://orcid.org/0000-0003-3869-2826

\section{ТЕЛЕФОН, СКАЙП И ИЗБЕГАНИЕ ВСТРЕЧ В ПСИХОАНАЛИЗЕ КАРЬЕРНЫХ КРИЗИСОВ}

«Всякий невроз имеет в себе фиксацию, но не всякая фиксация приводит к неврозу, совпадает с ним или встает на его пути»

3. ФрейӘ

Данный доклад представляет собой собрание некоторых размышлений и наблюдений по поводу карьерных кризисов. Размышления эти касаются определенных точек «бифуркации", которые анализанты встречают на своем жизненном пути. Эти точки можно трактовать как «кризисы», которые с одной стороны наносят психические травмы человеку, с другой стороны - могут стать трамплином для изменения дальнейшего жизненного пути, а могут образовать «запруды», выбраться из которых помогает работа с психоаналитиком. При этом в связи с пандемией и локдауном возникает вопрос целесообразности работы аналитика с анализантами виртуально через современные технологии связи. И встает вопрос - возможно ли выбраться из психической «запруды» виртуально?

В этом докладе мы сфокусируемся на исследовании означающих «карьера», «работа», «труд», «успех», «кризис» и остальных связанных с данным направлением размышлений, а также на теории травмы 3.Фрейда и вопросе регрессии в работах разных психоаналитиков, в том числе и К.Г. Юнга. 
Исследуя означающее «карьера», мы находим в словарях определение от происхождения (итал. carriera - бег, жизненный путь, поприще, от лат. carrus - телега, повозка) - до современного означающего как успешного продвижения в области служебной, социальной, научной и другой деятельности; Малый энциклопедический словарь 1907 даёт такое определение карьере: «Карьера (слово французского происхождения) быстрый успех на службе и другом поприще». В Толковом словаре живого великорусского языка Владимира Даля это слово означает «Поприще - ср. (nonupamb) вообще место, простор, пространство, на коем подвизаются (действуют, подвигствуют; арена, сцена, ипподром, приспособленное место для бега, скачек, для ристалищ, игр, борьбы и пр.».

Слово "работа" связано с общеславянским корнем *orbъ. Изначально этот корень имел значение - «слабый», «беспомощный». От него произошли русские слова ребёнок, раб и работа (напрямую с ним связано и немецкое arbeit - работа). Работой наши предки называли тяжёлую, подневольную деятельность, рабство. Впрочем, неодобрительно к работе относились не только славяне. Основой же для французского travail, испанского trabajo, португальского trabaiho - современных слов, обозначающих работу, - стало латинское слово tripalium (три палки). Им в Средние века в Европе называли распространенную пытку орудием с тремя кольями.

При этом в индоевропейском праязыке было слово werg, которое обозначало действие, занятие. Но сохранилось оно в английском, где work и сейчас значит работа, и в немецком, где слова arbeit и werk - синонимы.

Слово труд - это общеславянское производное от латинской основы trudo - «принуждаю», «заставляю». В древнерусском языке слово труд кроме работы, рвения и старания обозначало также страдание и скорбь. 
Идеальным вариантом стало бы производное от латинского слова labor, laboris - «напряжение, усилие, труд». Слово «лаборатория» относится к этой же группе.

Я думаю, мы можем полагать, что карьера представляется успехом в продвижении на поприще (месте) работы, поприще, занимаемом месте, которое может рассматриваться как место в том числе беспомощности, пытки, принуждения, страдания, напряжения усилий.

Само же слово «усnех» происходит от гл. успеть, спеть, и словенск. spẹh (род. п. spẹha, spehû) «поспешность, процветание Связано со спеть («становиться спелым»). Ср. лат. spēs, -е̄̄̄, мн. spērēs «ожидание, надежда», spērāre «надеяться, ожидать».

Мы можем предположить, что успех в карьере связан со спелостью на определенном поприще, месте и связанными с ней надеждами на получение и пользование плодами, исходами, результатами.

Карьерный же кризис связан с переворотом, переломом этого состояния. Слово «кризис» происходит от др.-греч. крібıц «решение, исход», родств. крі́v $\omega$ «различаю, сужу». В ряде европейских языков слово заимств. через лат. crisis. Кри́зис (др. -греч. крі́бı - решение; поворотный пункт) - переворот, пора переходного состояния, перелом, состояние, при котором существующие средства достижения целей становятся неадекватными, в результате чего возникают непредсказуемые ситуации. Кризис проявляет скрытые конфликты и диспропорции. В изначально медицинском определении понятия «кризис» определялось состояние пациента, выход из которого ведёт либо к его смерти, либо к возрождению.

Как психоаналитики, мы можем предположить, что кризис наступает тогда, когда субъект не в состоянии получать разрядку напряжения уже доступными и апробированными способами. 
Не следует забывать и о травматических событиях. Напряжение и отсутствие удовольствия, которое приносит карьерная деятельность, в некоторых случаях становятся невыносимыми, и субъект обращается за помощью к психотерапевту, психоаналитику.

Мои наблюдения показывают, что карьерные кризисы часто связаны с ситуациями, похожими на те, которые Фрейд описал в подходе к конфликту влечений в работах «Три очерка по теории сексуальности» (1905) и «Влечения и их судьбы» (1905), где психосексуальное развитие объясняется на языке изменений в биологическом и психическом функционировании индивидуума. Опыт человека на каждом этапе оставляет свой отпечаток в виде установок, черт личности и ценностей, приобретённых в соответствующей фазе. Также кризисы напоминают процессы, подобные тем, которые в политэкономической области описал В.И. Ленин в работе «Маевка революционного пролетариата» (1913), как составляющие революционной ситуации: «Верхи не могут управлять по-старому невозможность господствующего класса сохранять в неизменном виде своё господство. Низы не хотят жить постарому - резкое обострение выше обычной нужды и бедствий угнетённых классов и их желание изменений своей жизни в лучшую сторону».

Возвращаясь к психоанализу вспомним, что в попытках передать свои клинические интуиции о патогенезе травматического невроза, Фрейд прибегал то к метафоре постоянного воспаления, вызываемого присутствием инородного тела в организме, то к метафоре постоянной боли от внутренней грыжи. Обе метафоры справедливы: памятный след появляется в психике извне (как инородное тело), но сформировавшейся цепочке психических представлений-влечений необходимо (как и грыже внутреннего органа) найти место внутри; но не внутри организма, а внутри психического аппарата для этого следа. 
Так что, когда пациент с травматическим неврозом заявляет, что “Это невозможно себе представить, и что Я об Этом не могу рассказать словами”, то отчасти так Это и есть. Сбой изобразимости (нехватка психических ассоциаций) затрудняет разрядку квантов либидо, которыми заряжен каждый след воспоминаний, в том числе травматичных. Субъективно кванты либидо переживаются как аффективные заряды; в случае травмы, - в случае избытка несвязанных с представлениями, свободных квантов - этот избыток переживается как аффект тревоги, вторично запускающий целую гамму других болезненных аффектов (от беспомощности до вины).

В этом докладе я приведу примеры двух психоаналитических виньеток карьерных кризисов и виртуального подхода к работе с ними. Как наталкивают меня мои размышления - оба примера связаны с проблемой психической травмы и попыткой овладеть объектом, установить над ним контроль. Хотя, ясное дело - реперных точек для поворотных моментов на карьерном поприще очень много. И задача психоаналитика в анализе карьерных кризисов состоит в том, чтобы сделать то, что невозможно помыслить - изобразимым, используя тот запас означающих, который есть в распоряжении психоаналитического альянса.

Сам Фрейд приходил к мысли о существовании влечения к овладению, об изначальном стремлении к овладению самим собой, усматривая его основу "в попытках ребенка владеть (Herr werden) свочм телом".

Опираясь на эти мысли Фрейда, я прокомментирую несколько психоаналитических виньеток из моей психоаналитической практики. Конечно, я изменила имена и некоторые детали истории клиентов.

Виньетка №1.

Лейла, 43 года. Обратилась с жалобами на низкую удовлетворенность жизнью. По ее словам, жизнь после 40 лет это «кошмар», она ищет ответ на вопрос «Когда ей станет лег- 
че». Лейла материально содержит почти весь свой род: мужа, ребенка, родителей. Жалуется, что «все на ней».

Сеансы психоаналитического консультирования 1 раз в неделю уже 4 года. Первый год работы сеансы происходили с частотой 2 раза в неделю, но по ее просьбе уменьшили (она не успевает, по ее словам, осмыслить предыдущие встречи).

Привлекательная, статная женщина, любит носить платья, по ее словам. Ко мне же на сеансы приходит обычно в брюках. Замужем. Есть дети. Она директор в крупном бизнесе.

У Лейлы с детства очень привязанные отношения с матерью. Она постоянно думает о ней, звонит ей почти каждый день. Мать она описывает как властную и требующую, а отца как безвольного и зависимого. Многие годы Лейла каждый день звонила матери с докладом как прошел ее день, выслушивая материнские советы и назидания по любому поводу. Отец не принимал активного участия в жизни Лейлы, часто занимал дистантную или сочувствующую позицию по отношению к единственной дочери. С началом психоаналитических консультаций Лейла смогла занять комфортную для себя дистанцию в отношениях с матерью и звонить ей около одного раза в неделю, не особо волнуясь о том, что та ей скажет в качестве недовольства в ответ.

До последних лет Лейла была увлечена своей работой. Ей очень нравится общение с людьми и директорская должность. Когда я общаюсь с ней, то чувствую душевную теплоту и одновременное отчаяние какой-то неизбежно надвигающейся катастрофы или конца света на работе и в семейной жизни.

С 19 лет карьерные успехи Лейлы шли вверх, но в ее опыте было несколько случаев, когда работодатель увольнял Лейлу по причине того, что, по его словам, «она не справляется с рабочими обязанностям». Лейла тяжело переживала такие увольнения без выплаты ей заработной платы и отпускных, но она боялась подавать в суд жалобу или претензию на работодателя, несмотря на то, что считала задолженность по кон- 
тракту с ней весьма существенной и значимой для себя суммой. Работодатель для Лейлы является слишком влиятельной и всемогущей фигурой, с которой не стоит спорить. С матерью она также никогда не спорила. Соглашалась.

Сейчас Лейле также очень сложно находить способы гармоничного делового общения с настоящим работодателеммужчиной. По ее словам, он орет на нее, критикует при других членах коллектива, обвиняет в низкой сообразительности. Лейла теряется в разговоре с ним, иногда плачет.

Она была очень рада тому, что начался локдаун, ее компания перешла на дистанционную работу, ей не нужно было посещать нервный офис. Наши сессии в связи с локдауном стали происходить по телефону.

Первые месяцы карантина мы воспринимали телефон, как вполне приемлемый способ общения. Но со временем из нашего с Лейлой аналитического телефонного общения стала уходить какая-то «живая жизнь» и мне постепенно стало даже скучно так общаться. Наши разговоры были какие-то искусственные, вынужденные. Лейла говорила о том, что ей лучше работать вживую, но со временем стала переносить и отменять сессии, брать длительные перерывы между сессиями.

Лейла говорит, что у нее нет близких друзей, ее отношения сводятся к деловым контактам. Говорит, что психоаналитик - это единственный человек, с которым у нее близкие отношения. Но, похоже, даже этих отношений она начала избегать. В какой-то момент я поймала себя на мысли, что выслушивать по телефону ее жалобы по поводу тупика в жизни мне становится очень тяжело. Она мечтает уволиться из крупной компании и начать свой бизнес. Но не предпринимает к этому действующих шагов. Сомневается, что ее муж сможет содержать семью.

Ей не нравится ее тело, ее широкие бедра, она считает себя толстой (при этом имеет средний вес), отчаянно хочет похудеть, при этом очень часто и много ест. В ее речи звучат противоречия: «я хочу выстроить свой бизнес и послать это 
все» и «я хочу остаться спокойно здесь работать, так как уже поняла, чего ждать от этого работодателя», а также ее личной жизни: «я хочу развестись», «когда все это закончится?», «ненавижу эти ляжки», «сколько можно жрать?», «еда - единственное удовольствие, которое у меня есть», «я хочу сидеть дома и готовить, заботиться о детях», «я хочу, чтобы мужчина обо мне заботился, а я сидела дома с детьми», «мне нужен муж, который обо мне заботится».

Кризисный момент отсутствия контакта с работодателем Лейлы совпал с кризисным моментом переживания изменений ее телесности. Лейле сложно принять процессы постепенного увядания ее тела (она привыкла быть привлекательной, худощавой женщиной), как и сложно принять факт того, что ей нужно подчиняться руководителю, который гораздо моложе ее. До этого времени руководили Лейлой старшие мужчины.

По ее мнению, она достигла потолка карьерного продвижения в ее области на сегодняшний день. Называет его «тупик». Лейла чувствует непроходимый тупик и выносит смертный приговор для себя в этих областях - карьере и любви «будет только хуже». Она паникует, плачет. Говорит, что ей «очень тяжело». Иногда ее отчаяние в связи со столкновениями с этими «тупиками» принимает форму беспричинного гнева, истерик, скандалов с мужем, детьми.

Лейле сложно, по ее словам, «стареть», терять место «объекта нежности и заботы» в отношениях с мужчинами и место «гуру» в общении с сотрудниками. Сойти с этого места и занять другое она сопротивляется - видит тупик и унижение в бытии в иной ипостаси. Лейла говорит, что по требованию матери, с ранних лет должна быть элитой общества, отличницей, медалисткой - а стала отбросом общества. Это состояние тянется уже больше года. Лейла обратилась за медикаментозной помощью к психиатру. Выполняет его назначения.

Работа с Лейлой продолжается. После многочисленных переносов «виртуальных встреч» по телефону, она согласи- 
лась на встречу в личном формате, после моего предложения. В нашей работе появилась жизнь, живой интерес.

\section{Виньетка №2}

Майкл, 44 года. Женат около 12 лет, двое сыновей. Специалист в области информационных технологий. Обратился по поводу кризиса в жизни и карьере, а также беспокойства по поводу общения в виртуальных профессиональных социальных сетях, где получил, как он говорит, гомосексуальные угрозы, как показалось, от одного из членов виртуального сообщества. Мы встречались с периодичностью раз в неделю. Локдаун не остановил наше общение - мы перешли в телефонный режим.

Жалобы Майкла были связаны с потерей жизненных ориентиров, неудачами на местах работы, откуда ему пришлось увольняться или его увольняли. Как он говорит, «меня выживали младшие наглые коллеги и женщины», «они меня байкотировали и мне пришлось уволиться». На момент обращения Майкл уже год находился без работы. Жена посоветовала ему поработать с психологом и он обратился ко мне, так как знал меня лично по работе.

Майкл - активный участник виртуальных IT форумов. Как он говорит, он - уважаемый «член сообщества». Но в последнее время избегает посещений виртуальных дискуссий, так как на форуме некто пригрозил «трахнуть в жопу» по причине несогласия с его профессиональным мнением в IT платформе. Майкл очень растерялся, даже испугался этой угрозы, говорил об этом случае на сессии: «Представляешь! Что я ему сделал, что он со мной так?». Теперь он избегает чатов и онлайн-дискуссий.

В детстве наиболее яркими воспоминаниями Майкла были его братья и их хулиганские компании. Сейчас Майкл много рассказывает о своем сексуальном интересе ко многим девушкам. Все, что ему нужно, по его словам - это секс и покой. Семейные обязанности его тяготят, дети и жена раздражают. Он специально организует себе выезды в провинциальные 
города Украины, так как «проститутки там дешевле и послушнее в разы, чем в Киеве».

Сейчас Майкл нашел новую работу в области IT на руководящем уровне в крупной компании. После этого он сообщил мне, что собирается «закончить свою работу с психологом» и посвятить освободившееся время и деньги работе с массажисткой. Такая «работа» над собой его будет устраивать больше.

За время нашей работы Майкл свою (или жены?) задачу решил - он нашел новую высокооплачиваемую работу после года поисков.

Подводя итоги по поводу виртуального подхода к психоанализу карьерных кризисов, хочется отметить, что в моих идеях во время работы с клиентами появлялись и такие соображения, которые свидетельствовали о углублении психоаналитического взгляда сопровождения феноменов кризисов. Особенно в контексте работы с беспомощностью, «опускания рук», растерянностью, бегством, отчаянием и остальных признаков регрессии, которые демонстрировали и озвучивали анализанты.

К. Г. Юнг поставил вопрос о признании телеологического значения регрессии. Он считал, что возврат к инфантильному, беспомощному уровню - это не только регрессия, но и возможность нахождения нового жизненного плана.

То есть регрессия, по существу, есть также основное условие для творческого акта. ческой литературе проблема регрессии обсуждается с точки зрения причин ее возникновения, этапов развития, глубины проявления, объекта и субъекта цели, результатов работы, целесообразности сдерживания или активизации в процессе аналитической терапии.

Наряду с негативным значением регрессии, ведущей к симптомообразованию, рассматриваются и ее позитивные значения в качестве побуждения к восстановлению нарушенного равновесия, промежуточного состояния к осуществлению адаптивной переориентации. Такое состояние может быть 
достигнуто в аналитическом процессе путем символизации того «о чем невозможно было подумать».

В центре внимания аналитиков оказывается также регрессия как механизм защиты Я, «плохая» регрессия как состояние дезинтеграции и «хорошая» регрессия как прогрессивный процесс, необходимый для жизнедеятельности человека.

Ведь не даром говорят, что утопающему нужно достичь дна, чтобы от него оттолкнуться и пойти вверх к воздуху. Но для этого нужно «плавцу» успокоиться и иметь возможность опираться на себя и свою уверенность в собственных силах, узнать которые возможно в полной картине в зеркале, который с большим интересом к личности анализанта, поднимает психоанализ. И виртуальность в выражении этого интереса -скорее помеха. Ведь сколько бы различных экранов, проводов связи в мире технологий сейчас не существовало бы, люди до сих пор не отказались от стеклянно - оловянного зеркала, которое было изобретено в 1279 году. Поэтому классический сеттинг психоанализа является не технологическим атавизмом, а экологичной средой жизни аналитического общения людей.

\section{Литература:}

1. Фрейд 3. Введение в психоанализ / пер. с нем. Г. В. Барышниковой. Москва: АСТ, 2019. - 544 с.

2. Фрейд 3. По ту сторону принципа удовольствия. - Харьков: Фолио, 2013. -288 c.

3. Фрейд 3. Влечения и неврозы. - Москва: Академический проект, 2007. - 233 с.

4. Фрейд 3. Исследования истерии - Москва, 2005

https: / /avidreaders.ru/book/issledovaniya-isterii.html

5. Фрейд 3. Торможение, симптом и страх (1926)

6. Юнг К. Тавистокские лекции. - Астер-Х, 2015. - 122 с.

7. Ленин В.И Полное собрание сочинений. Том 23. Ева Дейл «Работа с травмой в психоаналитичеком подход https://www.hse.ru/ma/therapy/ news/454362676.html

8. Жан Лапланш, Ж-Б. Понталис "Словарь по психоанализу" https://consense.com.ua/ru/lib/showbook/psychoanalysis_vocabulary

9. Толковый словарь Даля онлайн http://slovardalja.net 


\section{ПРИКЛАДНІ ЗАСТОСУВАННЯ ПСИХОАНАЛІЗУ \\ В ЕПОХУ ВІРТУАЛЬНОГО}


УДК 159.942.5:[616.98:578.834-036.21]:159.9.072

DOI

\section{Маріанна Ткалич}

доктор психологічних наук, професор кафедри психології Інституту підготовки кадрів Державної служби зайнятості України (м. Київ, Україна), психоаналітичний психотерапевт за методом символдрама, член Дивізіону “Психоаналітична психологія і психотерапія" Національної психологічної асоціації України https://orcid.org/0000-0003-4101-9659

\section{ДИНАМІКА ПСИХОЕМОЦІЙНИХ СТАНІВ УКРАЇНЦІВ ПІД ЧАС ПАНДЕМIÏ COVID-19: МОЖЛИВОСТІ ТА ОБМЕЖЕННЯ ОНЛАЙН ДОСЛІДЖЕНЬ}

У березні 2020 року ми вперше зіткнулися з пандемією таких масштабів, спричиненою Covid-19. Серед глобальних заходів подолання пандемії, які суттєво вплинули на організацію та здійснення психологічної допомоги, проведення психологічних досліджень, став режим соціальної самоізоляції та соціальної дистанції, які унеможливили на деякий час очну роботу та можливість взаємодіяти з респондентами face-to-face. Пішов деякий час на те, щоб адаптуватися для цих змін: психотерапевтам та психологам перейти в онлайн, перевести на онлайн платформи навчання, створити нові можливості для проведення психологічних досліджень - так само онлайн - на спеціалізованих платформах або у різних месенджерах.

В чому проблема цього переходу? В першу чергу, це стосується проблематики досліджень - не всі теми та проблеми можуть бути досліджені онлайн, це особливо стосується психологічної травми, насильства, втрати, досліджень глибинних 
проблем. По-друге, це методика дослідження - ті психологічні методи, які зазвичай використовуються, особливо проективні методи, глибинне інтерв'ю - мало придатні для онлайн платформ або месенджерів. Методики довелося адаптувати в тому числі під Вайбер або Телеграм. Це знижує валідність та надійність даних, але іншим варіантом було - не проводити їх певний час взагалі. Як показав досвід - адаптація методик та тематики досліджень стала більш вдалим вибором, оскільки пандемія затягнулася і сподівання впоратися з нею за пів року не виправдали себе. Третьою важливою проблемою стала репрезентативність вибірки досліджень. Тепер у дослідженнях брали участь ті, хто мав доступ до інтернету та мав смартфони таким чином певну категорію ми не могли «дістати»: бідні, ті, хто живуть у віддалених районах, літні люди (старше 65-70 років) які просто «випадали» з вибірки. I вони випадають не лише із досліджень, а й з можливості отримувати якісну та кваліфіковану психологічну допомогу.

Частину цих проблем нам вдалося подолати, репрезентативність вибірки намагалися максимально зберегти - і це при наявності серйозних потужностей збору даних, які забезпечила Соціологічна група Рейтинг у одному з психологічних досліджень на великих вибірках - вивченні психоемоційних станів українців під час пандемії та їі динаміки [1]. Метод збору даних: інтернет опитування методом Computer-Assisted Self Interviewing (CASI) здійснено на основі випадкової вибірки мобільних телефонних номерів. Метод дослідження: опитувальник емоційного самопочуття, призначений для вивчення емоційного стану, складається із 5 шкал: депресія, тривога, паніка, розлади сну, втома (A. Aluoja et al., 1999) [3]. Загальна кількість опитаних у 4 хвилях впродовж 2020 року - 6800 осіб. Вибірка репрезентативна за статтю, віком, рівнем доходів, місцем проживання. Окремо аналізувалися відмінності за віком, гендером, зайнятістю, локусом контролю та сімейними взаєминами. 
Результати опитування у всіх хвилях зафіксували наявність в респондентів ознак депресії, тривожності, паніки, втоми і розладів сну. Порівнюючи результати опитування в останній хвилі з попередніми хвилями помітно незначне зростання депресії та падіння тривожності. Рівні паніки, втоми та розладів сну залишилися на тому ж рівні. Остання хвиля відбувалася як раз у карантин.

Підвищення рівня депресії ймовірно пов'язане із фізичними обмеженнями (малорухливість, менша активність) та відсутністю достатньої кількості зовнішніх подразників: нових вражень, подій, інтенсивності взаємодії з іншими. Життя на карантині - це часто «день бабака», - монотонна одноманітність, яка призводить до зниження настрою, млявості. До того ж депресія міцно пов'язана із втомою (чим вищий рівень втоми, тим вищий - депресії) та розладами сну (так само). Виявлена тривожність $€$ ситуативною (виникає внаслідок дії незвичних стресових факторів середовища), на відміну від особистісної, яка $\epsilon$ константною психологічною властивістю індивідів. Падіння такої тривожності вірогідно пов'язане із адаптацією до нових умов, зниженням відчуття невизначеності. Карантин перестав бути незнайомим явищем, а саме такі явища змушують людину тривожитися. Рівень паніки в цілому від початку карантину залишався на дуже помірних рівнях, а зараз її зростання видається вже малоймовірним, оскільки цей стан виникає у відповідь на реальну або вдавану серйозну загрозу, пов'язана із сильними негативними переживаннями щодо незвичної ситуації. До того ж паніка у психологічно здорової людини - це короткочасний стан - від декількох хвилин до декількох днів, які вже минули від початку карантину.

Аналіз результатів за віком показав у динаміці помітне зростання розладів сну у представників середніх вікових груп (30-49 років) та втоми у респондентів передпенсійного віку (50-59 років). Попри це серед останніх фіксується зниження рівня тривоги. Така ж тенденція $\epsilon$ і серед найстарших. 
За гендерним розподілом, жінки надалі демонструють вищий рівень усіх емоційних показників, аніж чоловіки і це $\epsilon$ традиційним показником для жіночої вибірки [2]. У динаміці за цей час жінок помітне зниження рівня тривоги, - вони краще адаптувалися та призвичаїлися до змін. У чоловіків фіксується зростання показників депресії та розладу сну, які міцно пов'язані між собою.

Зайнятість. Серед тих, хто має роботу помітні нижчі показники розладів сну та депресії, аніж у тих, хто не працює хоча б віддалено. Робота допомагає урізноманітнити життя на карантині, частково зберегти активність, спілкування та взаємодію, відволіктися від негативних думок та мати більш усталений розпорядок дня. Ті, хто мають можливість ходити на роботу, зберегли більшу частину свого звичайного життя та робочої взаємодії, ніж ті, хто працює віддалено.

Локус контролю досліджувався 2 окремими питаннями, не визначався за допомогою методики. В такому форматі, з'ясовано, що ставлення до життєвих обставин та контролю за ними має значний вплив на формування психоемоційного стану. Інтернали, які беруть відповідальність за успіхи та невдачі, події у житті на себе, почуваються значно краще - в них нижчий рівень за всіма показниками, а особливо - за рівнем депресії. В екстерналів, які відповідальність за своє життя віддають зовнішнім факторам, навпаки - рівні психоемоційної напруги достатньо високі.

Атмосфера у сім'ї $\epsilon$ важливим фактором впливу на психоемоційний стан опитуваних. Серед тих, хто характеризував сімейні відносини як спокійні, рівень негативних емоцій та станів значно нижчий, ніж у інших. Сім'я у цьому випадку виступає ресурсом підтримки у ситуації карантину і допомагає знизити напругу та стрес. Психоемоційний стан тих, хто вважає, що його взаємовідносини у сім'ї мають різний характер, схожий до тих, хто не має взагалі відносин. Винятком $\epsilon$ рівень 
тривоги, який у сімейних $\epsilon$ вищим. Серед тих, хто не перебуває у відносинах, тривожність на такому ж рівні, як у в тих, хто вважає свої відносини спокійними. Серед тих, хто перебуває у напружених стосунках, рівень негативних психоемоційних станів дуже високий. У їхньому випадку сім'я навпаки $\epsilon$ додатковим подразником та стресором, не створює підтримки, відчуття захищеності. До того ж на карантині, мало можливостей проводити менше часу в родині із напруженими стосунками - перебування всіх разом тривалий час $\epsilon$ додатковим фактором погіршення і без того конфліктної атмосфери. Можна припустити, що саме ця група у пост-карантинні часи $\epsilon$ групою ризику щодо зростання кількості розлучень.

Отже, сьогодні ми маємо можливість здійснювати психологічні дослідження в онлайн форматі, це вже майже не викликає подиву та супротиву. Аналіз результатів дослідження психоемоційних станів показав не лише рівні паніки чи депресії або розладів сну. Він так само показав, що в онлайн форматі $\epsilon$ можливість отримувати надійні дані (це підтверджено у 4 хвилях), в яких багато матеріалу для аналізу та інтерпретацій, побудові гіпотез та розробці стратегій психологічної допомоги. Перспективним вбачається все ж таки подальша розбудова спеціалізованих онлайн платформ, а не використання телефонів та месенджерів, що підвищить надійність даних, хоч і обмежить репрезентативність вибірки.

\section{Література:}

1. Емоції і поведінка українців: спеціальний проект. Режим доступу:

http://ratinggroup.ua/research/ukraine/emocii_i_povedenie_ukraincev_na_ karantine_specialnyy_proekt.html

2. Ткалич М.Г. (2016). Гендерна психологія: навч. посіб. - К.: Академвидав, 2016. - 256 c.

3. Aluoja, A., Shlik, J., Vasar, V., Luuk, K., Leinsalu, M. (1999). Development and psychometric properties of Emotional State Questionnaire, a self-report questionnaire for depression and anxiety. Nordic Journal of Psychiatry, 53, 6, 443-449. 
УДК 159.923.2:004.5

DOI

\section{Ельвіра Македонська}

Психолог, здобувач Ph.D. з психології, член Європейської Асоціації Психологів-Сексологів (ЕАПС) та Дивізіону “Психоаналітична психологія і психотерапія” Національної психологічної асоціації України

https://orcid.org/0000-0001-8864-8167

\section{ФЕНОМЕН РОЗВИТКУ ВПЕВНЕНОСТІ У СОБІ В ОНЛАЙН СЕРЕДОВИЩІ}

Феномен впевненості вже більше половини століття знаходиться в центрі уваги вітчизняних і зарубіжних психологів. Незважаючи на значне число робіт, присвячених вивченню впевненості, слід зазначити, що на сьогоднішній момент відсутня єдність поглядів в розумінні й тлумаченні цього психологічного явища. Окрім цього, з огляду на високий рівень використання Інтернету серед дітей, молоді, дорослих у XXI ст., видається актуальним вивчення феномену розвитку впевненості у собі в онлайн середовищі та його впливу на фізичний, емоційний, психічний та психологічний стан.

На жаль, дослідження, що вивчають наслідки використання Інтернету серед людей загалом перебувають у зародковому стані. Більшість досліджень, що пов'язують Інтернет із самооцінками, зосереджувались на його впливі на особисте життя та добробут. Первинні дослідження користувачів Інтернету виявили, що використання Інтернету було у зворотному відношенні до соціальних контактів, причому його використання асоціювалося здебільшого з посиленою соціальною ізоляцією і навіть депресією. По факту досліджень, які б більш чітко розкривали феномен розвитку впевненості у собі в онлайн середовищі, зокрема його динамічність, гнучкість та сценарії впливу факторів поки що недостатньо. 
Метою дослідження $\epsilon$ поглиблення розуміння впевненості у собі, визначення характерних особливостей (тригерів) розвитку впевненості у собі в онлайн середовищі.

Досліджуваному у статті питанню присвячували свої праці такі науковці, як Фрейд 3. [6], Лейбин В.М. [1], Пепен Ш. [3], Семенович А. [5], Куттер П, Мюллер Т. [4], Мішечкіна М. [2], Гамбургер Ю., Вайнапель Г. [7], Шрау Г., Деннісон Р. [8] та ін. Фрейд 3. [6], Лейбин В. [1], Пепен Ш. [3], Семенович А. [5] розглядають нові підходи щодо розуміння впевненості в собі через філософію, психоаналіз, нейропсихологію. Мішечкіна М. [2] досить вдало розкрила складові впевненості у собі. АмічайГамбургер Ю., Вайнапель Г. [7], Шрау Г., Деннісон Р. [8] вивчали взаємодію в Інтернеті осіб із точки зору типу особистості: інтроверсія / екстраверсія, надаючи оцінку метакогнітивної обізнаності людини та моделюючи напрямок розвитку впевненості у собі в онлайн середовищі (висхідний / низхідний).

Сучасні люди живуть в світі Інтернету і цифрових технологій: оформляючи сторінки і спілкуючись в блогах, соціальних мережах, обмінюючись інформацією через сервіси миттєвих повідомлень і електронні енциклопедії, беручи участь в мережевих іграх, здійснюючи миттєві покупки тощо.

Інтернет-комунікація, віртуальна реальність, віртуальна особистість, віртуальний авторитет, кіберпростір, мережева (Інтернет-психіка), NET-мислення та NET-впевненість - це далеко не вся термінологія, яка пов'язана із поняттям онлайн («на лінії»). Всі зазначені якості віртуальної особистості представляються нам взаємопов'язаними і похідними від нової форми соціальної взаємодії - глобальної віртуальної інформаційної взаємодії.

Визначення характерних особливостей (тригерів) розвитку впевненості у собі в онлайн середовищі потребує розгляду самого концепту «впевненості» 3 точки зору психологічних наук без прив'язки до онлайн чи офлайн. 
У науковій доктрині феномен впевненості розглядається з різних позицій, а саме як психологічного стану і як особистісної характеристики. У психологічній науці такий поділ засновано на двох дослідних напрямках: 1) дослідження впевненості як стану, частіше позначається як «впевненість індивіда в правильності своїх суджень»; 2) дослідження впевненості в собі як особистісної характеристики.

Спираючись на вчення Фрейда, можна виділити три підходи, через які метапсихологія описує психічні процеси. Так, економічний аспект дає можливість вивчати процес розвитку впевненості у собі через категорію «енергії; динамічний аспект дозволяє розглядає психічні процеси, які пов'язані із впевненістю у собі як результат взаємодії «первинних потягів»; топографічний аспект дозволяє співвідносити впевненість у собі із суміжними поняттями, за допомогою яких можна описати психічний апарат людини (Его, Супер-Его або «Я», «Над- Я» і т.і.) (Фрейд 3., 2010) [6]. Із позиції стику психології і нейронауки, розуміння процесу розвитку впевненості у собі можливе через призму структури і функціонування головного мозку у поєднанні з вивченням психічних процесів людини. Окрім цього, знадобитися можуть знання в галузі філософії, нейробіології, психіатрії та інформатики. Як таємницю віри в себе з точки зору філософії впевненості у собі подають деякі науковці (Пепен Ш., 2019) [3] .У свою чергу, досягнення сучасної нейропсихології визнані як шлях до підвищення якості життя людини, адже винайдені «нові» механізми розвитку впевненості в собі, що автоматично вносить вклад в стратегію, тактику екологічного управління впевненістю в собі (Семенович А., 2010) [6].

Впевненість в собі - це психологічна риса, яка пронизує різні когнітивні області. Ця риса вміщує у собі широкий конструкт впевненості, адже іiі можна поширити на переконання про правдивість пророцтв подій, які можуть або не можуть 
відбутися в майбутньому. Можна простежити взаємозв'язок між фактором впевненості в собі і Я-концепцією, зафіксованих за допомогою нашої власної інтерпретації обізнаності (MAl, Schraw \& Dennison, 1994) [8].

Впевненість в собі - теж навик. Він входить в комплекс навичок асертивності. Саме асертивність дозволяє знаходити баланс між пасивним і агресивним стилем спілкування. Провокуючи порівняння з іншими можуть виникати сумніви в самооцінці, що може привести до проблем з психічним здоров'ям, такими як тривога і депресія. Відштовхуючись від цієї парадигми, Інтернет $\epsilon$ ні чим іншим як розширенням повсякденного спілкування людей, здатне демонструвати «цифрову» поведінку і розвивати навик впевненості в собі.

Впевненість в собі - це не статична, а динамічна міра. Наша впевненість у виконанні ролей і завдань, в аналізі різних ситуацій може збільшуватися і зменшуватися, і в деякі моменти людина може відчувати себе більш впевнено, ніж в інші. Низька впевненість може бути результатом багатьох факторів, в тому числі: страху перед невідомим, будь-якої критики, придушеним почуттям власної гідності, поганого, нестачі знань і попередніх невдач тощо.

Складовими впевненості служать наступні компоненти: особистісний (представлений «високим рівнем самооцінки» $\mathrm{i}$ «самоповаги» особистості), когнітивний (відображає силу переконаності людини у власній ефективності), емоційний (характеризує «сміливість» людини в соціальних контактах) і поведінковий (забезпечує зовнішню реалізацію поведінкового репертуару впевненості в собі) (Мішечкіна М. $€$., 2004) [2].

Риси особистості - це змінні, які координують людські дії $\mathrm{i}$ досвід за допомогою динамічної психологічної організації, i вони становлять головний дискримінант для визначення поведінкових патернів в мережі (Amichai-Hamburger, 2002) [7]. 
На нашу думку, впевненість можна трактувати як комплексну характеристику особистості, що представляє собою усвідомлення людиною самоефективності, прагнення до самодостатності, емоційну зрілість і впевнений поведінковий репертуар. Таке розуміння впевненості розширює можливості в плані вивчення реальності і їі формування. Адже впевненість дозволяє людині як «бути собою», так і «здаватися собою».

Досить часто розуміння впевненості у літературі розкривається через призму понять самовпевненість, самоповага, самоефективність, тим самим визначаючи специфічні характеристики даного феномену. Багато психологів схильні вважати, що концепція впевненості в собі пов'язана з більш широким уявленням про загальні здібності людини. Впевненість в собі веде до успішного досвіду, а успішний досвід - до підвищення самооцінки. Із цим не можна не погодитися, якщо детальніше зануритися у зміст кожного поняття.

Самовпевненість - це надвпевненість (когнітивне упередження) у своїй здатності досягти мети, інколи із нелінійними реакціями («ефект вибуху»), незважаючи на всі об'єктивні труднощі й проблеми на шляху досягнення цілі. Деяким особам надвпевненість в собі також приносить відчуття щастя. У таких випадках людина отримує більше енергії і натхнення, долаючи ментально будь-який «ефект складності».

Самоповага - це оцінка власної цінності, яка виражається у ставленні людей до себе, яка служить «термометром» суспільного визнання. Людей з високим рівнем самоповаги характеризує специфічне ставлення до картини світу, адже самоаналіз буквально пронизує їх увесь час із нав'язливим компонентом самооцінки. Існує золота середина, коли особа визнаєте той факт, що $є$ цінною людиною. У той же час, перебільшення власних достоїнств, здібностей та навичок, видається оточуючим людям егоїстичним і зарозумілим. Самоповага - це ті самі «точки опори», які протистоять натиску чужих очікувань. 
Самоефективність - це віра в свою здатність досягти успіху в конкретній ситуації на «піку» потенціалу. Йдеться про віру людини в свої здібності щодо конкретного завдання або набору задач. Самоефективність працює на цілі, стратегію, тактику людини. Це також пов'язано з успішністю, спираючись на впевненість в собі і впливаючи на самооцінку. Самоефективність працює по принципу сумарного ефекту синергії тіла, душі, розуму.

Коли люди відчувають невпевненість в собі і низьку самооцінку, у них може розвинутися те, що часто називають синдромом самозванця. Хоча це офіційно не зареєстровано як емоційне захворювання, психологи визнають вплив, який він справляє на людину, i те, як воно також може бути пов'язано з тривогою і депресією.

Виходячи з викладеного впевненість можна трактувати як комплексну характеристику особистості, що представляє собою усвідомлення людиною самоефективності, прагнення до самодостатності, емоційну зрілість і впевнений поведінковий репертуар. Таке розуміння впевненості розширює можливості в плані реальності іï вивчення і формування. Адже впевненість дозволяє людині не тільки продуктивно вирішувати поставлені перед нею завдання, а й відчувати багатогранність буття, переживати радість творення і подолання.

Розвиток впевненості у собі в онлайн середовищі доцільно розглядати через призму причинно-наслідкових зв'язків. Представлені дослідження засновані на різних концептуальних моделях. В якійсь мірі вони відносять особистість в Інтернеті як до незалежної змінної, іноді як до залежної змінної. Крім того, деякі дослідження описують взаємодію між особистісними і ситуативними аспектами. Тож, особистість в онлайн середовищі може перебувати як фактор впливу (на інших) та як елемент впливу (з боку інших). 3 цього слідує, що особистість в Інтернет може бути як: 1) незалежною, так і 2) залежною змінною. 
Безліч питань психологічних досліджень поведінки особистості в мережі найкраще впорядкувати, розглядаючи передбачувані причинно-наслідкові зв'язки і наслідки.

Особистість як незалежна змінна впливає на поведінку в Інтернеті: особистість впливає на поведінку людей в Інтернеті, тим самим відбувається безпосередній вплив на розвиток впевненості. Наприклад, риси особистості можуть впливати на вибір онлайн-контенту, інтенсивність використання певних онлайн-сервісів або можуть привести до спільної переваги онлайн-спілкування в порівнянні з особистим спілкуванням.

3 іншого боку, зміни розвитку впевненості у собі регулюють силу впливу особистості на онлайн-поведінку: в порівнянні з першою точкою зору, адже на вплив особистості на ії онлайн-поведінку також впливають модеруючі змінні. Ці змінні визначають, наскільки інтенсивно особистість виражається в Інтернеті. Фактори модерації можуть включати різні онлайнсервіси, рівні анонімності, рівні близькості або інші аспекти, які розрізняються в межах онлайн-середовища. Цей підхід враховує, що на поведінку впливають не тільки аспекти особистості, але також ситуативні і контекстні умови. Саме тут доцільно говорити про ситуаційний вплив Інтернет-середовища. Екстравертні люди в онлайн середовищі будуть проявляти себе більш активно, ніж інтравертні [7], [8].

На особистість як залежну змінну впливають незалежні змінні: якості онлайн-середовища призводять до зміни особистості, ступеня впевненості у собі. Цей підхід передбачає, що в порівнянні з офлайновою особистістю люди в онлайн середовищі систематично змінюються. Звичайно, зміна особистості також призводить до зміни поведінки та впевненості в прямому слідстві. Тож, ця точка зору відноситься і до особистості як до залежної змінної, і до особистості як посередника між аспектами онлайн-середовища і онлайн-поведінкою. Анонімність 
в мережі змушує людей ставати більш екстравертними (i, отже, вони також ведуть себе більш екстраверт нота впевнено).

Особистість як модераторська змінна регулює силу впливу незалежних змінних на поведінку в мережі. Ця точка зору передбачає вплив певних характеристик онлайн-середовища на поведінку. Особистість регулює ці відносини. Це означає, що вплив не поширюється на всіх людей однаково. Вплив варіюється в залежності від їх особистісних структур, зокрема надуманого віртуального авторитету.

Процеси взаємодії особистості, онлайн-середовища і поведінки теж потребують ретельного вивчення. Цей підхід, в деякому роді, об'єднує всі вищезгадані точки зору. Він вказує на те, що різні точки зору не виключають одна одну, але, взяті окремо, розглядають тільки одну частину дуже складної системи взаємодій. Поняття взаємодії має на увазі, що змінні впливають одна на одну (особистість може впливати на поведінку в Інтернеті і навпаки), а також включає в себе ефекти стримування. Емпірично цей підхід, звичайно, важче за все реалізувати і його важко знайти в недавній дослідницькій літературі. Поки немає теоретичних моделей, які б досить точно відображали складну взаємодію між різними особистісними характеристиками користувачів Інтернету, конкретними характеристиками онлайн-середовища і онлайн-поведінкою в контексті феномену «впевненість». Адже, як відомо, екстравертні люди більш соціально залучені, тому екстраверсія ще більше зростає. 3 іншого боку, інтроверти соціально виключені, тому i екстраверсія зменшується [7].

Причини невпевненості клінічні психологи, психоаналітики, гештальт-психологи, соціальні психологи в собі пояснюються різними фахівцями по-різному: невпевненість в собі передається у спадок - клінічні психологи, несвідомого витісненого конфлікту - психоаналітики, навішування ярлика через призму оточення соціальні психологи, опору спонтанності - гештальт-психологи. 
Без сумніву в інформаційному просторі спостерігається розподілена свідомість віртуальної особистості, адже можливим видається одночасне заняття різних віртуально просторових і особистісних позицій, що обумовлено базовим ступенем впевненості у собі. Крайнім вираженням цього ефекту $\epsilon$ «розщеплення» віртуальної особистості, «розщеплення» іiі свідомості і мислення, «розщеплення» іï впевненості у собі. Перебуваючи в онлайн середовищі людина здатна як підвищити ступінь впевненості у собі (або закріпити), так і занизити ступінь впевненості у собі (або зруйнувати).

Взаємозв'язок між використанням Інтернету (Інтернетсерфінгом), соціальною підтримкою та власним «Я» вказує на ефекти фонових характеристик, яких набуває феномен впевненості у собі. Принаймні, це передбачає, що різні форми спілкування можуть мати різний вплив на формування впевненості у собі в онлайн середовищі. NET-мислення та NETвпевненість тут відіграються чи не визначальну роль.

Висновки. За результатами виконаного дослідження можна стверджувати, що:

- наша особистість $\epsilon$ джерелом наших емоцій, пізнання i поведінки. Ї̈̈ структуру порівнюють зі структурою величезного айсберга, в якому під поверхнею чимала кількість незвіданого. Впевненість як стан розуму базується на законах звичної людської поведінки, фізичному та метафізичному законах;

- в контексті онлайн середовища концепт впевненості у собі набуває особливого змісту та характеристик. Інтернеттехнології актуалізують інтрапсихічні смисли і переводять їх в міжособистісний контекст. Визначення смислів в Інтернетспілкуванні - один із способів розвитку особистості, формування їі впевненості у собі.

- складовими впевненості служать наступні компоненти: особистісний, когнітивний, емоційний. Впевненість у собі - це не статична, а динамічна міра, входить в комплекс навичок 
асертивності; невпевненість у собі - здебільшого ярлик для події незвіданого.

- особистість в онлайн середовищі може перебувати як фактор впливу (на інших) та як елемент впливу (з боку інших). Особистість в Інтернет може бути як незалежною, так і залежною змінною. Результатом розвитку впевненості у собі можуть бути: підвищення ступеня впевненості у собі (або закріплення) чи заниження ступеня впевненості у собі (або руйнація).

Перспективами подальших досліджень у цьому напрямі $\epsilon$ дослідження кореляцій онлайн-середовища, онлайн-поведінки та типу особистості (інтроверсія / екстраверсія) в контексті феномену розвитку впевненості у собі.

\section{Література:}

1. Лейбин В.М. Психоанализ // Новая философская энциклопедия / Ин-т философии РАН; Нац. обществ.-науч. фонд. 2-е изд., испр. и допол. М.: Мысль, 2010.

2. Мішечкіна М. Є. Історичний та психолого-педагогічний аспекти поняття впевненості в собі / М. Є. Мішечкіна // Зб. наук. пр. Бердян. держ. пед. ун-ту. Пед. науки. 2004. № 1. С. 114-123.

3. Пепен Ш. Філософія впевненості в собі / Шарль Пепен ; [пер. з фр. В. Барської]. Харків : Vivat, 2019. 189 с.

4. Психоанализ. Введение в психологию бессознательных процессов. Куттер П, Мюллер Т. М.: Когито-Центр, 2011. 384 с.

5. Семенович А. В.. В лабиринтах развивающегося мозга: шифры и коды нейропсихологии / А. В. Семенович. М. : Генезис, 2010. 424,

6. Фрейд 3. По ту сторону принципа удовольствия // Очерки по психологии. Минск: Попурри, 2010. 480 с.

7. Amichai-Hamburger, Y., Wainapel, G., \& Fox, S. (2002). On the Internet no one knows I'm an introvert: Extroversion, neuroticism, and Internet interaction. CyberPsychology \& Behavior, 5(2), 125-128. https: / /doi.org/10.1089/109493102753770507

8. Schraw, G., \& Dennison, R. S. (1994). Assessing metacognitive awareness. Contemporary Educational Psychology, 19(4), 460-475.

https://doi.org/10.1006/ceps.1994.1033 
DOI

\section{Ірина Франкова}

Лікар-психолог, к. мед. н., асистент кафедри медичної психології, психосоматичної медицини та психотерапії НмУ імені О.О. Богомольця, груповий аналітик (АППУ, ЕFPP), ко-тренер секції групової психоаналітичної

психотерапії Асоціації психоаналітиків та психотерапевтів України https://orcid.org/0000-0001-9371-6849

\section{ПСИХОСОМАТИЧНИЙ СИМПТОМ У ПРИЗМІ ГРУПОВОГО АНАЛІЗУ}

Групова психотерапія $\epsilon$ центральним компонентом стандартного стаціонарного лікування психосоматичних та найрозповсюдженіших психічних захворювань (афективні, тривожні, постстресові, невротичні розлади).

Основна ідея застосування групового підходу в лікуванні полягає в тому, що типові міжособистісні конфлікти пацієнтів, які спричинили порушення ментального стану, виникатимуть щодо групи, у комунікації з окремими пацієнтами та ведучими групи. Ці міжособистісні та групові конфлікти, що виникають у групі, можуть бути використані як з діагностичною, так і терапевтичною метою. Пацієнти можуть використовувати групу як навчальну ситуацію для практики нових міжособистісних форм поведінки.

Саме в психосоматичному стаціонарі на групі нерідко можна почути наступний діалог між пацієнтом та ведучим групи:

- В мене пече в ділянці сонячного сплетіння, клубок у горлі, болить голова, як ніби, хтось здавлює ії обручем. Каже пацієнт.

- А що ви відчуваєте? Можливо, вам здалось, що хтось проявив до вас агресію? Чи ви ображені? - Питає груповий терапевт.

- Я не знаю. Я не розумію. Я зовсім не ображаюся, чому ви так вирішили? 


\section{Алекситимія}

Саме таким чином пацієнт описує конфлікт у своїх стосунках, і через такий спосіб психосоматичним пацієнтам часто приписують іпохондричність, так ніби вони зациклені на тілесних відчуттях. Насправді це не так. Коли пацієнт скаржиться, ми спостерігаємо тілесні компоненти емоцій, що виникли у відповідь на конфлікт (ком в горлі, біль), але пацієнт їх не усвідомлює, тому й не може вербалізувати.

3 нейробіологічної точки зору складність з вербалізацією виникає через недостатність нейронних зв'язків між (1) лімбічною системою, (2) асоціативною корою головного мозку (відповідає за сприйняття і зберігання інформації з різних аналізаторів, в тому числі від тіла), і (3) скроневими та лобними відділами кори головного мозку, що відповідають за сприйняття i артикуляцію мови. Описане явище лежить в основі сучасного розуміння такого феномена, як алекситимія та в нейронауці має назву недостатнього нейронного пруннінга (Sander, 2013). Алекситимія тісно зв“язана із психосоматичною медициною та появою психосоматичних симптомів, сучасні дослідники виділяють чіткі критерії для даного феномену (Fava et al., 2017).

Тож, щоб підтвердити наявність алекситимії потрібна присутність трьох і більше з наступних 6 характеристик:

1. Нездатність/складність підібрати слова для опису емоцій;

2. Тенденція описувати деталі замість почуттів (наприклад, обставини, що оточують, а не почуття);

3. Відсутність багатої фантазії, внутрішнього життя;

4. Зміст думок пов'язаний більшою мірою з зовнішніми подіями, ніж з фантазією або емоціями;

5. Незнання загальних соматичних реакцій, які супроводжують переживання різних почуттів;

6. Раптові, часто недоречні, агресивні спалахи.

Якщо людина погано розуміє власні емоційні реакції, не дивно, що емоції інших людей для неї теж $є$ недоступними для 
розуміння. Тож алекситимія робить взаємостосунки досить складними.

\section{Невербальна комунікація}

Значний внесок у розуміння особливостей формування міжособистісних стосунків i ïх значення для розвитку психосоматичних розладів роблять сучасні дослідники теорії прив'язаності такі як Беатріс Біб. Вона займається спостереженням за немовлятами за допомогою мікроаналізу (Beebe et al,, 2010). Доктор Біб вивчає якість невербальної комунікації між матір'ю і дитям віком 4 місяці за допомогою посекундного детального аналізу відеозаписів одночасно з обличчя матері та дитя під час їх взаємодії. За допомогою даного спостереження виявлено, що якість невербальної комунікації в 4 місяці визначає стиль прив'язаності дитини у віці 1 року, а також:

- соціальний і когнітивний розвиток дитини;

- здатність переносити та регулювати стрес;

- здатність до емпатії;

- здатність формувати любовні відносини та можливість вступати в близькі стосунки.

\section{Матір Сім'я Соціум}

Рис. 1. Динаміка формування стосунків від народження

Тож природа контакту дитини з грудьми матері, з матір'ю, а пізніше з сім'єю предиспонує спосіб і характер побудови стосунків із соціумом (Рис.1). Тож з алекситимічність пов'язана з низьким рівнем налаштованості, емпатії та сприйнятливості з боку опікунів. 


\section{Стиль прив'язаності та психосоматика}

Відомо, що у дорослих розподіл стилів прив'язаності виявлених за допомогою інтерв'ю розробленого Мері Мейн (Adult Attachment Interview, M. Main) виглядає наступним чином:

- Надійно безпечний стиль прив'язаності - (50-65\%);

- Уникаючий стиль прив'язаності - (20-30\%);

- Амбівалентний (тривожний) стиль прив'язаності - (15-20\%);

- „Не розв’язана травма“ - (19\%).

Чи цей розподіл справедливий і для пацієнтів психосоматичного стаціонару? Виявляється ні. У вибірці психіатричних пацієнтів ( $\mathrm{n}=439)$ превалював стиль прив'язаності “нерозв'язана травма” (40\%) (Van ljzendoorn, 1995). Серед пацієнтів 3 депресією превалював амбівалентний стиль прихильності (50\%) (Dozier, 2008). Варто пам'ятати, що активується та чи інша система прив'язаності й в ситуації хвороби, а не тільки небезпеки чи сепарації.

Тож в психотерапевтичній групі психосоматичного стаціонару ми частіше за все стикаємося з пацієнтами з ознаками надмірної залежності та сепараційної тривоги, вони часто суперечливі в зображенні минулих прив'язаностей, їм бракує об'єктивності (амбівалентний стиль). А пацієнти з «не розв'язаною травмою“ внаслідок травматичного досвіду часто мають зловживання або обривають зв'язок (довгі паузи, беземоційність, жорстокість).

Для дорослих людей підтримувати контакт з афективним життям групи може виявитися настільки ж важким завданням, як і для немовляти встановлення контакту з материнськими грудями. 3 моменту появи на світ людина існує і розвивається тільки в тісній взаємодії із собі подібними, (сім'я, соціум). Поза цим оточення саме фізичне виживання індивіда більш ніж сумнівно, а психічне становлення його як людини просто неможливо. 


\section{Комунікація і терапевтичний процес}

Комунікація в групі - процес фундаментальний. Комунікація це усі процеси, які протікають між людьми в групі (свідомі та несвідомі, навмисні і ненавмисні, зрозумілі і незрозумілі). Будь то вербальні, невербальні послання або скарги на симптоми. Психосоматичний симптом - це спроба висловити конфлікт (як наведено у прикладі на початку даного тексту) і одночасно бажання приховати його, це так зване компромісне утворення. Коли проблема усвідомлена вона може бути комунікована (почута) і зрозуміла за допомогою проговорення. В групаналітичному підході нам звично говорити про так звану “групову матрицю” - гіпотетичну мережу комунікативних зв'язків і відносин між членами групи. Річ у тому, що учасники групи формують перенесення не тільки на ведучого групи, але й один на одного, а також до групи як до єдиного цілого. У відношенні один до одного, щодо психотерапевта і групи учасники також розвивають специфічні способи поведінки. Мета в групової психотерапії з позиції групаналітичної теорії полягає у впливі на зв'язаність, комунікацію і взаємодію між учасниками.

\section{Ефективність групової терапії}

Групова терапія ефективна як амбулаторний метод лікування при різних психологічних розладах, коли пацієнти отримують лише групове лікування (Burlingame, MacKenzie, \& Strauss, 2004), так і для стаціонарних пацієнтів (Kösters, M., Burlingame, G. M., Nachtigall, C., \& Strauss, В. (2006). Дослідження Kordy, H., Von Rad, M., \& Senf, W. (1990) показує, що 90\% пацієнтів приписують частину покращення свого стану досвіду перебування в терапевтичній групі та розглядають іï як центральний по важливості досвід лікування в стаціонарі.

В більшості емпіричних досліджень групової психотерапії для виміру ефективності науковці зосереджувались на змінних про відносини у групі, а саме: 
> когезія (згуртованість), що включає відносну прив'язаність членів групи один до одного, до ведучого, а також до групи в цілому

> груповий клімат

$>$ терапевтичний альянс

$>$ емпатія

> відчуття себе учасником групи

Рівень когезії становить особливий клінічний інтерес для дослідників, оскільки міжособистісні проблеми типових психосоматичних пацієнтів часто стосуються проблем з регулюванням близькості та відстані у відносинах (Burlingame, G. M., McClendon, D. T., \& Yang, C. (2018). Хоча при більш детальному вивченні літератури можна знайти суперечливі дані щодо ефекту та значення когезії на поліпшення стану пацієнтів в процесі лікування (Рис. 2).

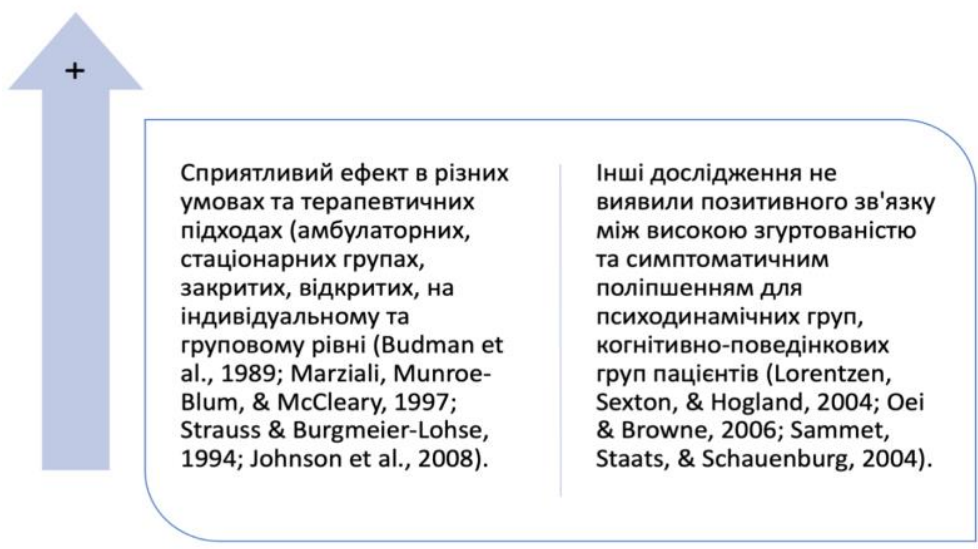

Рис. 2. Ефект когезії на лікування 
Вивченням даної дилеми та ефекту індивідуальної когезії й інтерперсонального стилю (приналежність чи домінування) на результат психодинамічно-орієнтованої групової терапії у рамках стаціонарного лікування займається німецький психосоматолог Геннінг Шауенбург (Dinger, U., \& Schauenburg, H., 2010). В дослідження під його керівництвом увійшли 327 пацієнтів (226 жінок, 101 чоловік), які проходили лікування мультимодальною стаціонарною груповою психотерапією в університетській клініці Гьоттінген, Німеччина. У пацієнтів превалювали діагнози: афективні розлади (61,5\%), тривожні $(24,2 \%)$, розлади харчової поведінки $(18,7 \%)$, соматоформні розлади $(15,3 \%)$, розлад адаптації $(8,0 \%)$, обсесивно-компульсивний розлад $(4,6 \%)$. Результати показали, що вищий рівень згуртованості (когезії), а також збільшення ступеня згуртованість 3 часом були пов'язані з поліпшенням симптомів у психічній сфері. 3 літератури також відомо, що пацієнти з високим рівнем дистресу відчувають нижчий рівень згуртованості, а низька згуртованість, в свою чергу, $\epsilon$ предиктором поганої відвідуваності групової терапії (Ogrodniczuk, Piper, Joyce, 2006).

Важливою знахідкою стало те, що пацієнти, які повідомляли про міжособистісні проблеми до лікування, а саме занадто доброзичливе ставлення до оточення, мали покращення загального стану під час стаціонарної групової терапії, коли їх особистий досвід згуртованості зменшувався (тобто дистанція стосовно інших учасників збільшувалась). А пацієнти з міжособистісними проблемами, пов'язаними з низькою приналежністю (наприклад, ворожість або холодність), повідомляли про значне зменшення симптомів, коли їхнє почуття згуртованості зросло. Це трактувалось як зростання компетенцій, комплементарних провідній проблемі пацієнтів.

Група має стати таким простором, в якому можливі менталізація та рефлексія (Fonagy, 2013) щодо наступних тез:

- Бачення себе та інших як думаючих і відчуваючих 
- Переймання різних перспектив/ точок зору

- Антиципація реакції інших

- Рефлексія зміни внутрішніх станів та їх наслідків

\section{Висновки}

Якість невербальної комунікації в парі мати-немовля, стиль прив'язаності та рівень алекситимії грають важливу роль у розвитку психосоматичних захворювань. 3 нейробіологічної точки зору це пов'язано з недостатнім нейронним пруннінгом. Психоаналітична теорія та теорія прив'язаності перекидає місток від низького рівня налаштованості, емпатії та сприйнятливості матері в ранньому віці немовля до проблем 3 емпатією, регуляцією стресу та дистанції в стосунках із соціумом, що призводить до браку соціальної підтримки та психосоматичної хвороби. Ефективним амбулаторним так і стаціонарним методом лікування $\epsilon$ групова терапія, де з позиції групаналітичної теорії основна мета полягає у впливі на зв'язаність, комунікацію і взаємодію між учасниками відповідно до провідних проблем пацієнтів. Бо різні пацієнти отримують користь від різних аспектів групової терапії в залежності від їх стилів прив'язаності.

\section{Література:}

1. Burlingame, G. M., Fuhriman, A., \& Johnson, J. E. (2004). Process and outcome in group counseling and psychotherapy. Handbook of group counseling and psychotherapy, 49-61.

2. Burlingame, G. M., McClendon, D. T., \& Yang, C. (2018). Cohesion in group therapy: A meta-analysis. Psychotherapy, 55(4), 384.

3. Dinger, U., \& Schauenburg, H. (2010). Effects of individual cohesion and patient interpersonal style on outcome in psychodynamically oriented inpatient group psychotherapy. Psychotherapy Research, 20(1), 22-29.

4. Fava, G. A., Cosci, F., \& Sonino, N. (2017). Current psychosomatic practice.

Psychotherapy and Psychosomatics, 86(1), 13-30.

5. Bateman, A., \& Fonagy, P. (2013). Mentalization-based treatment.

Psychoanalytic inquiry, 33(6), 595-613.

6. George, C., Kaplan, N., \& Main, M. (1996). Adult attachment interview. 
7. Dinger, U., Strack, M., Sachsse, T., \& Schauenburg, H. (2009). Therapists' attachment, patients' interpersonal problems and alliance development over time in inpatient psychotherapy. Psychotherapy: Theory, Research, Practice, Training, 46(3), 277.

8. Kordy, H., Von Rad, M., \& Senf, W. (1990). Therapeutic factors of inpatient psychotherapy--the patients' view. Psychotherapie, Psychosomatik, Medizinische Psychologie, 40(9-10), 380-387.

9. Kösters, M., Burlingame, G. M., Nachtigall, C., \& Strauss, B. (2006). A metaanalytic review of the effectiveness of inpatient group psychotherapy. Group Dynamics: Theory, Research, and Practice, 10(2), 146.

10. Ogrodniczuk, J. S., Piper, W. E., \& Joyce, A. S. (2006). Treatment compliance among patients with personality disorders receiving group psychotherapy: What are the roles of interpersonal distress and cohesion?. Psychiatry: Interpersonal and Biological Processes, 69(3), 249-261.

11. Sander D. (2013). The power of emotions. Belin. P 171.

12. Stovall-McClough, K. C., \& Dozier, M. (2016). Attachment states of mind and psychopathology in adulthood. Handbook of attachment: Theory, research, and clinical applications, 715-738.

13. Van Ijzendoorn, M. H. (1995). Adult attachment representations, parental responsiveness, and infant attachment: a meta-analysis on the predictive validity of the Adult Attachment Interview. Psychological bulletin, 117(3), 387. 
НОТАТКИ КОНФЕРЕНЦІЇ 


\section{УдК 159.964}

DOI

\section{Мар'яна Великодна}

Психоаналітик ЄКПП, клінічний психолог, кандидат психологічних наук,

дочент кафедри практичної психології

Криворізький державний педагогічний університет Модератор Дивізіону “Психоаналітична психологія і психотерапія"

Національної психологічної асоціації України

https://orcid.org/0000-0001-6269-793X

Оксана Аршевська-Гєрен

Психоаналітичний психолог, клінічний психолог,

член і експерт з етичних питань

Дивізіону “Психоаналітична психологія і психотерапія"

Національної психологічної асоціації України

https://orcid.org/0000-0002-6991-0040

\section{РЕФЛЕКСІЇ УЧАСНИКІВ КОНФЕРЕНЦІї “ПСИХОАНАЛІЗ І ВІРТУАЛЬНЕ”}

У перший день конференції обговорення групи почалося з рефлексії Наталії Турбіної про те, що сьогодні через технічні збої під час онлайн-трансляції конференції дистанційним учасникам багато доповідачів наводили приклади віртуального як місця збою. Але варто зауважити, що Віртуальне - це не тільки збій. Це ще багато чого іншого, вартого уваги. Наприклад, окрім збоїв сьогодні віртуальне дало можливість нашому міжнародному і міжконтинентальному спілкуванню, щедрому обміну. І важливим $є$ те, чи можемо ми побачити це цінне у Bipтуальному у час, коли збій теж має місце.

Кілька учасників захотіли поділитися своїм досвідом як аналізантів у роботі онлайн. Одна учасниця розповіла, як важко їй залишатися у кімнаті, де щойно проходив сеанс, порів- 
нявши це із тим, як зі старого килима струснули пил і пил тепер стоїть у повітрі в кімнаті. Вона порівняла це з сеансами наживо, де якісь переживання і спогади можна ніби залишити на зберігання в кабінеті психоаналітика. I запропонувала ввести дуже чіткі етичні правила щодо такої практики.

Ведучий групи Валерій Дорожкін відповів, що це може бути дуже привабливим - поквапитися ввести певні універсальні правила, але насправді багато порушених сьогодні слушних питань іще потребують часу на відстеження і осмислення, а головним орієнтиром все ж $є$ конкретний клінічний випадок, який варто оцінити як унікальний і приймати рішення у світлі цієі окремої історії.

Наталія Наливайко наголосила, що сеанси онлайн роблять більший внесок у дорослість наших аналізантів, оскільки ми тепер ділимо з ними відповідальність: за те, щоб знайти собі тихе і зручне місце, домовитися про вільний час зі співмешканцями. Це те, що в умовах кабінету $є$ повноваженням аналітика. I багато що в аналізі онлайн залежить від того, чи зможуть наші аналізанти з цим упоратися.

Цю думку підтримала і Галина Савченко. Вона зауважили, що аналізанти приходять в психоаналіз з певним усвідомленням того, що відбуватиметься, та залишаються в аналітичному процесі за власної волі і з власним бажанням. Галина Савченко наголосила на тому, що психоаналітична робота $\epsilon$ результатом співпраці двох їі учасників, та не варто боятися того, що наші аналізанти привносять до неї, навіть якщо це чашка з чаєм.

Мар‘яна Великодна поділилася ідеєю, що запит на введення рамок і правил може бути відображенням нашого відчуття нестачі обмежувальної батьківської функції - адже тепер двоє залучені в доволі інтимізований процес зустрічі, де дійсно хтось може бути і в домашньому халаті, наприклад. І цій діаді, потенційно перверсивній, може бракувати інстанції за- 
кону, який в кабінетній роботі здійснює загальний психоаналітичний сетинг: місце, час, заданий контекст зустрічі.

Ольга Павловська прокоментувала це своїм спостереженням, що віртуальне постійно вимагає реактивності, наприклад, перевіряти зв'язок чи реагувати на розрив зв'язку, і може бути дуже важливим не піддаватися цій реактивності. Сама Ольга Павловська не перепитує, якщо не розчула аналізанта, даючи можливість усьому важливому проговоритися ще якимось чином. Тим самим у онлайн-роботі створюється простір для пасивізації, до якої запрошено і аналізанта.

Інша учасниця, яка проходить свій аналіз, поділилася думкою про те, що бути аналізантом у піжамі чи з чаєм - не обов'язково про порушення рамки, особливо якщо такої рамки не було проговорено. Іноді це і вираження довіри, а без довіри психотерапія не зможе статися.

Другого дня конференції першим надав свої ідеї до обговорення доктор Едісон Паломіно. Він наголосив, підсумовуючи обговорення двох днів, що варто не вважати віртуальне Уявним. Віртуальне $\epsilon$ цілком Реальним, про що варто не забувати психоаналітикам, в той час як наші аналізанти мають таку спокусу. При очній роботі має місце фізично уреальнений перехідний простір, де аналізант долає шлях до кабінету аналітика. Але тим не менше, Віртуальне та його маніфестація $\epsilon$ проявами Реального, як, скажімо технічні, неполадки, що мали місце на конференції.

Тему переходу учасники прокоментували і в ключі того, що другий день завершували теми доповідей, які все більш апелювали до тілесного і до співбуття, до когезії, про яку говорила Ірина Франкова.

Наприкінці лунали численні подяки організаторам за чудову можливість взяти участь у конференції та почути цікаві доповіді. Окрім того, учасники зауважували на те, що сам формат конференції, а саме поєднання очної присутності з он- 
лайн можливістю долучитися до участі, спонукав до нових усвідомлень щодо можливостей та обмежень використання онлайну в психоаналітичній роботі.

Олег Христенко підкреслив, як важливо чути доповіді на різні теми, або з різними точками зору на одну і ту саму тему, що сприяло створенню більш об'ємного поля зору на предмет дискусії. Окремо була відмічена цінність присутності серед доповідачів спеціалістів з інших, ніж психоаналіз, галузей - це дає можливість познайомитися з колегами, що також працюють над ціллю психічного здоров'я, та побачити можливі шляхи співпраці, перетинання та об'єднання зусиль.

Мар'яна Великодна у своєму заключному слові нагадала, що ця конференція стала відповіддю на запит учасників попередньої конференції дивізіону [1] і певним втіленням ідеї Ольги Павловської про те, що одне із головних завдань психоаналітичної спільноти - контейнерувати переживання практиків, які виникають в клінічній роботі, та створення простору для їх сублімації [2]. Отже, усіх учасників запрошено до подальшої ревізії тем, які непокоять, для пропозиції проблемних питань наступних конференцій.

\section{Література:}

1. Життя і смерть психоаналітичних спільнот: уроки історії і нові перспективи об'єднань : Матеріали I Всеукраїнської науково-практичної онлайнконфе- ренції з міжнародною участю, 23-24 січня 2021 року, Київ, Мілан, Єреван, Токіо [Електронне видання]. - 168 с.

2. Pavlovska, O. (2021). Psychoanalytic society as a space for the wish existence [In Russian] In Life and death of psychoanalytic societies: lessons from history and new prospects for unions : Conference proceedings. The I-st AllUkrainian online conference with international participation, January, 23-24, 2021, Kyiv [electronic book]. pp. 90-97. 
Наукове видання

\section{Психоаналіз і Віртуальне: етика, метапсихологія і клінічний досвід позакабінетної практики}

Матеріали II Всеукраїнської науково-практичної конференції з міжнародною участю 12-13 червня 2021 року, Київ

Формат 60×84/16. УМ. друк. арк. 14,00. Обл.-вид. арк. 10,06.

Видавець Р. А. Козлов

вул. Рокоссовського, 5/3, м. Кривий Ріг, 50027

097-192-20-77

Свідоцтво суб'єкта видавничої справи

ДК № 4514 від 01.04.2013 р.

Друкарня С. Г. Щербенка «Літерія"

вул. Рокоссовського, 5/3, м. Кривий Ріг, 50027

097-192-20-77

Свідоцтво суб'єкта видавничої справи

ДК № 4561 від 13.06.2013 р. 